\title{
Preliminary Stratigraphic and Petrologic Characterization of Core Samples from USW-G1, Yucca Mountain, Nevada
}

\author{
Editors
}
A. C. Waters
P. R. Carrolf*
Contributors
D. L. Bish
F. A. Caporuscio
J. F. Copp
B. M. Crowe
J. D. Purson
J. R. Smyth
R. G. Warren

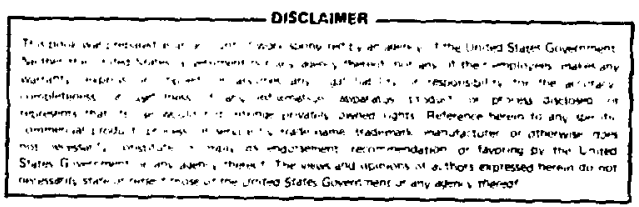

"Visiting Staff Member. 2100 East Galer Street, Seattle, WA 98112.

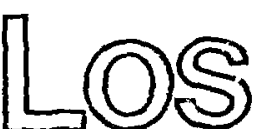

Alannos

Los Alamos National Laboratory Los Alamos,New Mexico 87545 
PRELIMINARY STRATIGRAPHIC AND PETROLOGIC CHARACTERIT.ATINN OF CORE SAMPLES FROM USW-G1, YUCCA MOLINTAIN, NEVADA

Editors

A. C. Waters and P. R. Cà,roll

Contributors

D. L. Bish, F. A. Caporuscio, J. F. Copp, B. M. Crowe, J. D. Purson, J. R. Smyth, and R. G. Warren

\section{ABSTRACT}

Tuffs of the Nevada Test Site are currently under investigation to determine their potential for long-term storage of radioactive waste. As part of this program, hole USK-G1 was drilled to a depth of $6000 \mathrm{ft}$ hel ow the surface, in the central part of the Yucca Mountain area, Mevada Test Site, Nevada. Petrographic study of the USW-G1 core is presented in this report and shows the tuffs (which generally were variably welded ash flows) are partly recrystallized to a variety of secondary minerals. The important alteration products are zeolites (heulandite, clinoptilolite, mordenite and analcime), smectite clays with minor interstratified illite, albite, micas, potassium feldspar, and various forms of silica. Iijima's zeolite zones I through IV of burial metamorphism can be recognized in the core. Zeolites are first observed at about the $1300-\mathrm{ft}$ depth, and the high-temperature boundary of zeolite stability in this core (beginning of Greenschist metamorphism) occurs at about $4350 \mathrm{ft}$. Analcime persists, either metastably or as a retrograde mineral, deeper in the core. The oxidation state of $\mathrm{Fe}-\mathrm{Ti}$ oxide minerals, through most of the core, increases as the degree of welding decreases, but towards the bottom of the hole, reducing conditions generally prevail.

Four stratigrapiiic units transected hy the core may be potentially favorable sites for a waste reporitory and are receiving more detailed mineralogical characterization in reports that are in preparation. These four units, in order of increasing depth in the core, are (1) the lower cooling unit of the Topopah Spring Member, (2) cooling unit II of the Bullfrog Member; (3) the upper part of the Tram tuff, and (4) the Lithic-rich tuff. 
The southwestern part of the Nevada Test Site (NTS) region, located in south-central Hevada, is currently under investigation with respect: to its suitability for siting of an underground repository for high level waste. This project, funded through the Nevada Nuclear Waste Storage Investigations, is part of an investigation of four major rock types as potential repository media: argillite, granite, tuff, and alluvium (Dixon et al., 1980). Current exploration efforts are now focused on tuff, principally in and near Yucca Mountain, a linear mountain rarge located within and adjacent to the southwestern boundary of the NTS (Fig. 1). Yucca Mountain is underlain by a thick sequerice of ash-flow and bedded tuffs, derived largely from the Timber Mountain-0asis Valley cauldron complex (Byers et ai., 1976; Christiansen et al., 1977). The curnulative thickness of tuff units in Yucca Mountain exceeds $6000 \mathrm{ft}$ and may be as great as $10,000 \mathrm{ft}$. These tuffs range in age from about 15 to 12 Myr.

A comprenensive exploration program of Yucca Mountain commenced in 1979. Exploration drill hole UE25a-i, located on the eastern edge of Yucca Mountain (Fig. 1), was drilled to a depth of $2500 \mathrm{ft}$ to investigate the stratigraphy and structure of the Yucca Mountain area. Geological and geophysical data from this exploratory drilt hole are summarized by Spengler et al. (19\%9). Following evaluation of data from that drill hole and from other exploration studies, a second exploration hole, USW-G1, was sited in the central part of Yucca Mountain and drilled to a depth of $6000 \mathrm{ft}$. The purposes of this hole are to investigate further the stratigraphy and structure of Yucca Mousitain and to determine the lateral continuity, conpetency, and mineralogy of periecrated tuffs. A preliminary core $\log$ and a geologic analysis of the USW-Gl core have been written by Spengler et al. (in preparation).

In this report we build on Spengler's core log to further characterize the stratigraphy and petrology of selected core samples through laboratory investigations. The chief method used in this preliminary study was microscopic petrography, aided by $x$-ray diffraction and microprobe studies of specific minerals. Particular attention was given to the paragenesis of devitrification products of volcanic glass--both those produced during the cooling history of the rock immediately after eruption and those occurring much later during $s$ ? ow diagenetic al terations that took place below (or above) the water table. Zeolite phases received particular attention as keys to paleotemperatures and paleohydrology. Oxidation states of the opaque minerals have been determined by analysis of their exsolution products (Haggerty, 1976). Clay minerals and their changes with depth have not been thoroughly analyzed for this drill core, and the silica minerals--opal, chalcedony, quartz, tridymite, and cristobalite--have received only cursory attention.

Ainong the primary minerals, special attention was given to phenocrysts. Phenocrysts and lithic fragments are useful aids in distinguishing certain horizons of tuff.

Tuff is a complex rock type that varies greatly in mineralogy, texture, and chemica? composition. The tuffs from USW-G1 show only limited variations in bulk chemistry, and their physical variations are controlled principally by their mode of emplacement (air-fall and ash-flow mechanisms) and by postemplacement alteration processes. Some alterations that occurred during cooling are welding, which produces significant variations in density and porosity of ash-flow tuff; primary devitrification, which causes subsolidus breakdown of glass to cristobalite and alkali feldspar; and the precipitation 


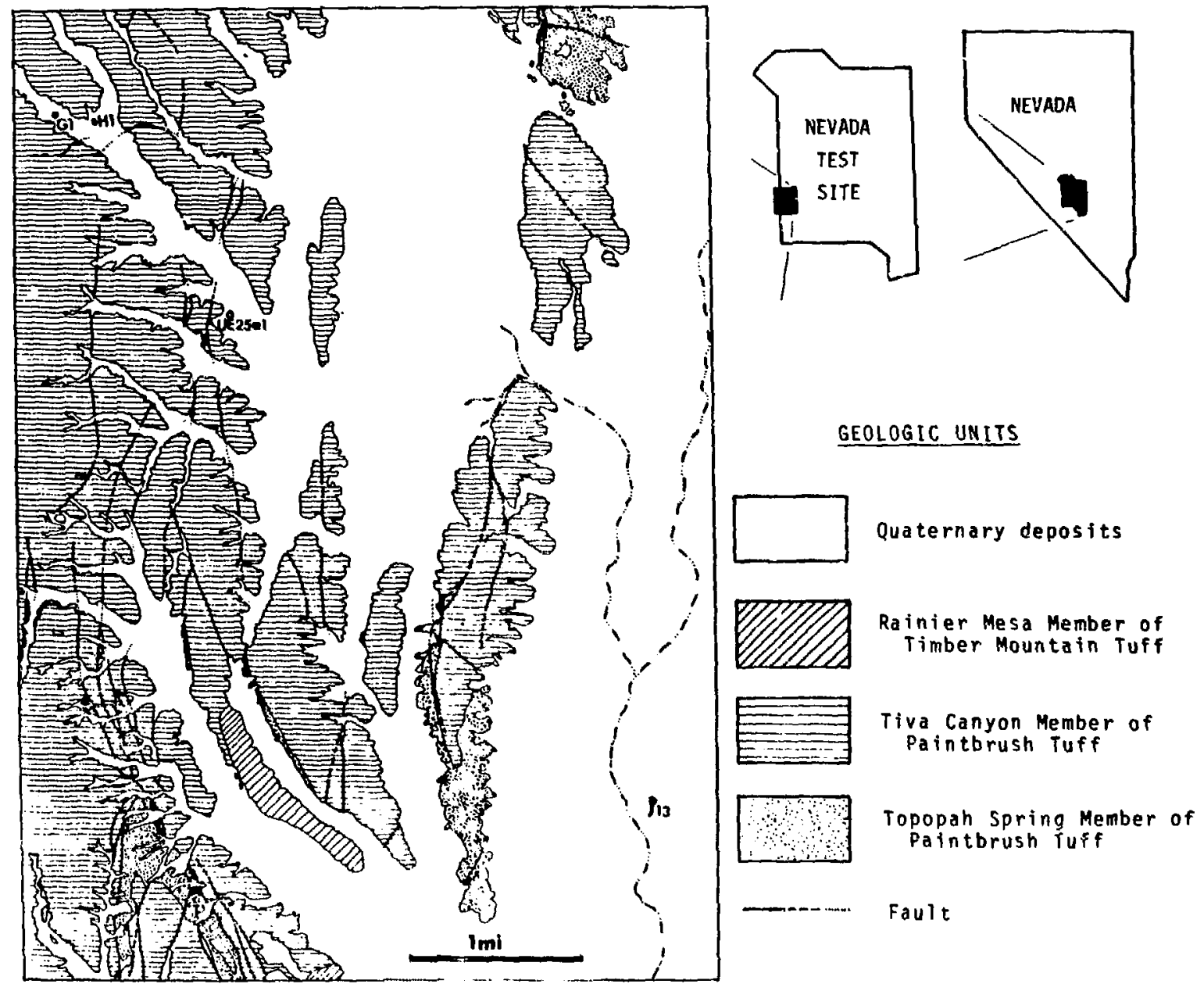

Fig. 1. Generalized geologic map of Yucca Mountain area, showing drill hole locations, from Topopah Springs NW quadrangle (Christiansen and Lipman, 1965). 
of vapor-phase minerals during degassing of the ash-flow deposits. Secondary alteration products, primarily clays, hydrous and other silica phases, zeolites, and authigenic feldspars, are formed long after emplacement and consolidation of tuff by alteration of glassy constituents of tuff by interaction with ground water and by the slight rise in temperature caused by burial.

Los Alamos National Laboratory has conducted oarlier mineralogic and petrologic studies of tuff in support of the drilling and exploration programs at the NTS. Core from the drill holes is characterized petrographically to define mineralogic and textural features of ash-flow and bedded tuff penetrated in the drill holes. Such data assist in understanding the vertical and horizontal variations in tuff units of Yucca Mountain and adjacent areas and their variations with respect to properties that affect the ability of tuff to isolate radioactive waste. For example, Wolfsberg et a1. (1979), Johnstone and Wolfsberg (1980), and Vine et a?. (1980) show that sorption data for tuff can be broadly grouped into two categories based on kind and degree of devitrification, and especially on the presence and abundance of zeolite and clay minerals. Lappin (1980) described grain density vs thermal conductivity trends for tuffs and developed a predictive curve for theoretical conductivity of tuff as a function of grain density. Heiken and Bevier (1979) described the petrology of tuff units from drill hole J-13 located in Forty Mile Wash on the western edge of Jackass Flat and adjacent to Yucca Mountain (Fig. 1). Sykes et al. (1979) described the mineralogy and petrographic features of tuff units from the UE25a-1 drill site. They noted that the principal zeolite mineral in the upper parts of the drill core is high-silica clinoptilolite and attributed its occurrence to ground-water alteration of glass in an open hydrologic system. Units penetrated by these drill holes are shown in Fig. 2.

\section{I. STRATIGRAPHIC AND LITHOLOGIC SUMMARY OF THE DRILL HOLE SECTION}

Drill hole USW-G1 was begun at an elevation of $4349 \mathrm{ft}$ and was ended $6000 \mathrm{ft}$ below that level. The core samples Quaternary and Tertiary deposits, the latter almost exclusively consisting of siliceous volcanic rocks, generally tuffaceous.

The Tertiary tuffaceous rocks cored contain representatives of two formally recognized formations--the Paintbrush Tuff and the Crater Flat Tuff (Christiansen and Lipman, 1965; Christiansen et al., 1977)--and also many other formal and informal members, or other subdivisions. Megascopic description of the core, and stratigraphic subdivision of the units cored, were accomplished by the U.S. Geological Survey (Spengler et al., in preparation). This work is sumnarized in Table I. We owe a great debt of gratitude to R. W. Spengler and his associates for copies of the core logs and for advice and encouragement during preparation of this report.

The Paintbrush Tuff and the Crater Flat Tuff are divided into members: the former comprising the Riva Canyon, Yucca Mountain, and Topopah Spring Members, and the latter the Prow Pass and Bullfrog members (all 1isted in order of increasing age). The Tram tuff is informaliy regarded as the lowest member of the Crater Flat Tuff. Several other informal units in the deeper parts of the core hole may ultimately be elevated to formation or member states.

The lowest unit of the Paintbrush Tuff (Topopah Spring Member) and the rocks of the core that underlie it are the subject of this report. Listed in 


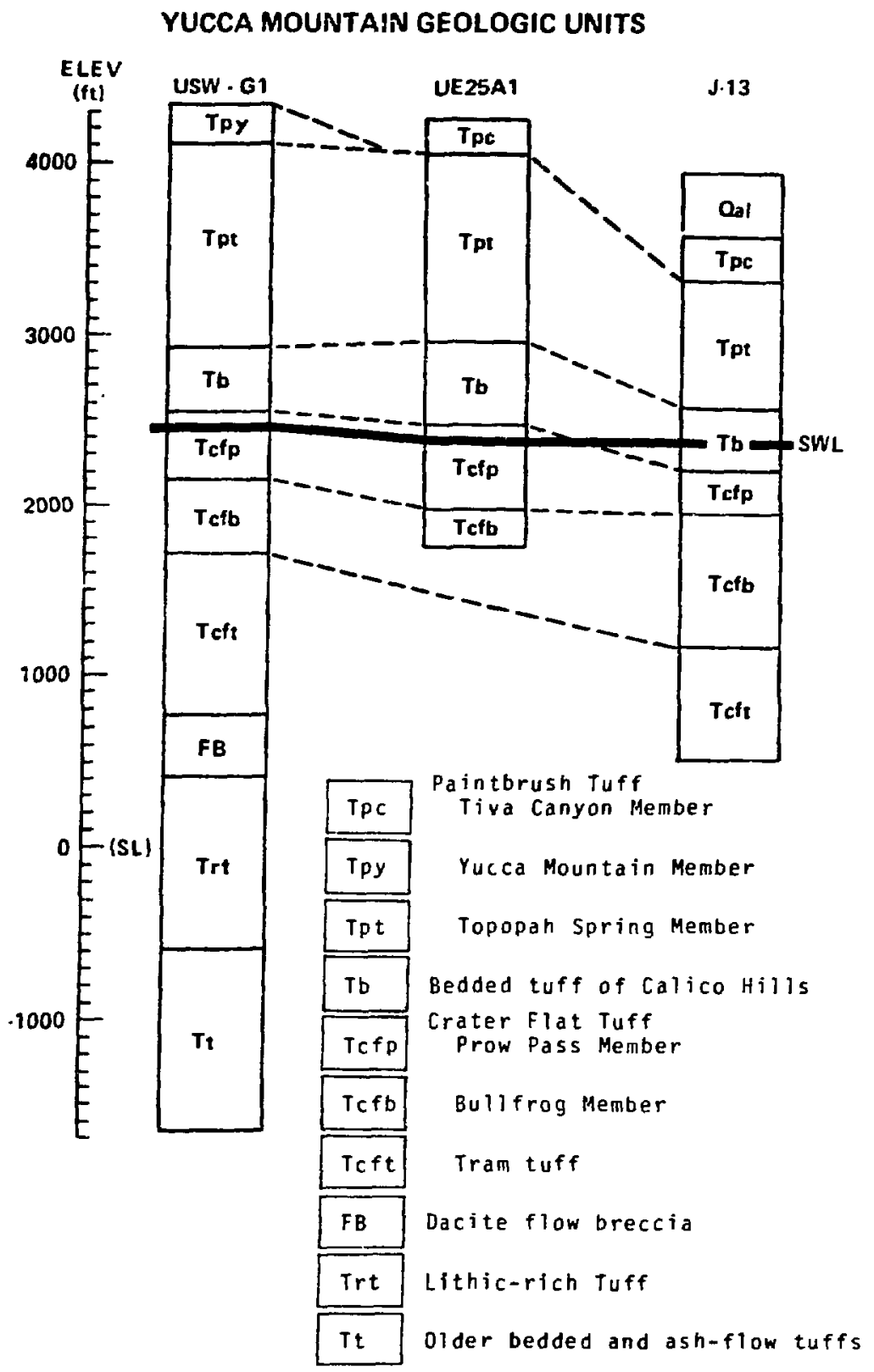

Fig. 2. Correlative geologic columns for drill holes USH-G1, UE25a-1, and $\mathrm{J}-13$, showing principal geologic units. Heavy black line is the static water level in the hole. 
TABLE I

SUMMARY OF STRATIGRAPHY AND MEGASCOPIR. ROCK DESCRIPTION OF CORE USW-GI

\begin{tabular}{|c|c|c|c|c|c|c|}
\hline $\begin{array}{l}\text { Major Stratt- } \\
\text { graphic Intervals }\end{array}$ & $\begin{array}{l}\text { Depth in Core } \\
\text { of Top and } \\
\text { Bottom of } \\
\text { Interval (ft) }\end{array}$ & $\begin{array}{l}\text { Thickness } \\
\text { (it) of } \\
\text { Interval }\end{array}$ & Rock Type(s) & $\begin{array}{l}\text { Phenocrysts-- } \\
\text { Types, Total } \\
\text { Percent of Rocks }\end{array}$ & $\begin{array}{l}\text { Welding of } \\
\text { Ash-flow Tuffs }\end{array}$ & Other tamients \\
\hline Alluvium & $0-60$ & 60 & Gravel, sond, silt & $\ldots$ & $\cdots$ & some colltche \\
\hline ( Yucca Mountaln & $60-135$ & 75 & Ash-flow tuff & --- & $\begin{array}{l}\text { Moniel ded to partially } \\
\text { velded }\end{array}$ & -- \\
\hline 产 $\left\{\begin{array}{l}\text { Pah Conyon } \\
\text { Nemer }\end{array}\right.$ & $135-235$ & 110 & Ash-fiew tuff & Sparse blot & Monmel ded & $\cdots$ \\
\hline $\begin{array}{l}\text { Topopah Spring } \\
\text { Muber }\end{array}$ & $235-1426$ & 1190 & $\begin{array}{l}\text { Dasa) bedded tuff, } \\
\text { ash bed at } 456 \mathrm{ft} \text {. } \\
\text { ash-flow tuff }\end{array}$ & $\begin{array}{l}\text { San. plag } \\
\text { top } 50 \text { ft--biot. } \\
\text { hrnbind, pymx } 0-21\end{array}$ & $\begin{array}{l}\text { Top to bottam--nomelded, } \\
\text { densely welded. } \\
\text { moderately to nonwelded }\end{array}$ & $\begin{array}{l}\text { Yapor phase cryst. } \\
293-1237 \mathrm{ft}\end{array}$ \\
\hline $\begin{array}{l}\text { Tuffacetius beds } \\
\text { of Caltio Hills }\end{array}$ & $1426-1802$ & 376 & $\begin{array}{l}\text { Ash-flow, ash-fall, mo } \\
\text { bedded, reworted tuffs, } \\
\text { from lia to } 0.5 \text { it thick }\end{array}$ & $\begin{array}{l}\text { Sen, plag, gtz } \\
\text { less then } 2 t\end{array}$ & $\begin{array}{l}\text { Monvel ded to slightly } \\
\text { weited }\end{array}$ & -- \\
\hline \pm (Mrow Puss & $1802-2173$ & $3 \eta 1$ & $\begin{array}{l}\text { Ash-flow tuff, basel } \\
\text { bedded, reworted tuff }\end{array}$ & $\begin{array}{l}\text { San, pleg, atz, } \\
\text { hrnbint, biot, } \\
\text { minor pyrox, 5-158 }\end{array}$ & $\begin{array}{l}\text { Partially to moderately } \\
\text { welded }\end{array}$ & $\begin{array}{l}\text { Lithic fragents-: } \\
\text { rd-brm mudstome } \\
\text { and brn-gry volcanic }\end{array}$ \\
\hline 岁 & $2173-2640$ & 467 & $\begin{array}{l}\text { Ash-flow tuff, in atdole } \\
\text { section is thin, beuded } \\
\text { tuff }\end{array}$ & $\begin{array}{l}\text { San, plag, qtz, } \\
\text { nrmbind, blot } \\
5-202\end{array}$ & $\begin{array}{l}\text { Monvel ded to moderstely- } \\
\text { to-densely welded }\end{array}$ & $\begin{array}{l}\text { Wthic frapents-- } \\
\text { wry-brn rolcanic } \\
\text { and rd-brn cudstome }\end{array}$ \\
\hline 51 Iran tuff & $2640-3558$ & 918 & $\begin{array}{l}\text { Busal bedded, reworted } \\
\text { tuff ind, cbove. ash-flow } \\
\text { tuff }\end{array}$ & $\begin{array}{l}\text { Sin, plag, qtz, } \\
\text { biot; pyrox? in } \\
\text { bottom ush-fiow } \\
\text { sheet. 10-15\% }\end{array}$ & $\begin{array}{l}\text { Monuel ded to } \\
\text { moderately welded }\end{array}$ & $\cdots$ \\
\hline Ducite flow brecela & $3550-3946$ & 300 & 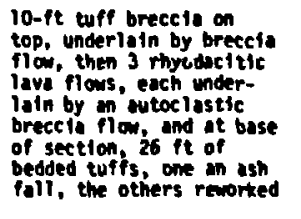 & $\begin{array}{l}\text { San, plag, qtz, } \\
\text { hrnbind, biot; } \\
\text { ash-fali hes bsot, } \\
\text { san, qtz, plag }\end{array}$ & $\ldots$ & $\begin{array}{l}\text { Apprectable lithic } \\
\text { fragents, rhyolitic } \\
\text { to basaltic in } \\
\text { composition }\end{array}$ \\
\hline Lithic-rich tuff & $3946-1940$ & 94 & $\begin{array}{l}\text { Upper } 975 \text { rt--one osh- } \\
\text { flow euff, the lower } \\
\text { ig ft ts bedded tuff }\end{array}$ & $\begin{array}{l}\text { Sen, plag, qtz. } \\
\text { nrublind biot. } \\
\text { spheme io-15i }\end{array}$ & Partially melded & 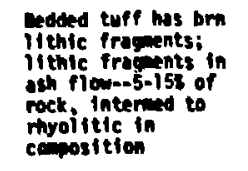 \\
\hline $\begin{array}{l}\text { ol dor bedded ind } \\
\text { wh-flow tuffs }\end{array}$ & $\begin{array}{l}4940-6000 \\
\text { (triting } \\
\text { irblererily } \\
\text { ended it } \\
6000 \mathrm{ft} \text { ) }\end{array}$ & 1060 & $\begin{array}{l}\text { Ash-flow tuffs, } 13 \\
\text { bedded, reworked tuffs } \\
\text { and } 2 \text { ish-foll tuffs; } \\
\text { thicknesses rangs from } \\
203 \text { to } 0.5 \text { ft }\end{array}$ & $\begin{array}{l}\text { San, plag, atz, } \\
\text { biot, ninor spheme } \\
\text { and hroblind 5-258 } \\
\text { iss overage }\end{array}$ & $\begin{array}{l}\text { Individual ash-flaw } \\
\text { yory from nonwelded } \\
\text { to donsely welded. } \\
\text { possibly up to } 14 \\
\text { compound cooling inits }\end{array}$ & $\begin{array}{l}\text { Lithic fragments-- } \\
0-32 \text { of rock. } \\
\text { intermed } 20 \text { inyolitic } \\
\text { in composition }\end{array}$ \\
\hline
\end{tabular}

\footnotetext{
Condensed from core lop supplied by spengler and assoclates.
} 
order of increasing age, they are the Topopah Spring Member of the Paintbrush Tuff, the Tuffaceous beds of Calico Hills, the Crater Flat Tuff (which includes Prow Pass, Bullfrog, and Tram tuff Members), the Dacite flow breccia, the Lithic-rich tuff, and 01 der undifferentiated ash flows and bedded tuffs (see Table I).

\section{PRELIMINARY PETROGRAPHIC CHARACTERIZATION OF THE USW-GI CORE}

\section{A. Foreword}

The general petrographic features of selected samples from the USW-G1 core are described here in the same order of stratigraphic assignment used by Spengler and associates in logging the core. Thin section samples obtained from the core are described fromi each of the formal and informal units listed by Spengler. Sample numbers used are the depth in the core (feet) from which the sample was collected.

Some topics discussed in this section, other than routine petrography, need to be introduced. Exsolution of opaque minerals has been studied to show the oxidation state of the rock (Haggerty, 1976). Phenocrysts are mentioned briefly for each stratigraphic unit, but certain special features of phenocrysts are prosented in much greater detail in a later section of the report. In the same way, details of zeolitization and alteration processes are the subject of a later, more detailed part of the report. A te've of $x$-ray diffraction analyses and supporting brief text are al so treated in later pages.

In logging the core Spengler and his associates divided the core into stratigraphic units on the basis of lithologic differences. In places our petrographic work shows that two or more of these subdivisions can be grouped into a single cooling unit, as defined by Smith (1960). In other places a lithologic unit may be separated from othei's by some unique feature of mineralogy or petrography. Such separations are noted in our text but no changes in the U.S. Geological Survey formal and informal stratigraphic designation of the core are suggested. Formal designation of stratigraphic units should await results from other core holes that may be drilled, and geologic, geophysical, and petrologic work that may be performed.

B. Topopan Spring Member of Paintbrush Tuff

The Topopah Spring Member occurs in USW-G1 drill core from 235 to $1425 \mathrm{ft}$, a thickness of $1190 \mathrm{ft}$. The Member is subdivided into 241 ithologic intervals: a bedded tuff at the base, an ash bed at $456 \mathrm{ft}$, and various ashflow units ranging from nonwelded to vitrophyric (Spengier et al., in preparation).

Five samples were selected from the lowest $240 \mathrm{ft}$ of the Topopah Spring Member for thin sectioning. The samples are believed to be part of a single cooling unit and are centered around a vitrophyre within the Topopah Spring Member. Of the five samples, the one lowest in the section (1392) is slightly zeolitized and only slightly to partly welded. The main portion of this sample is unaltered glass, with minor clinoptilolite. Zeolitization occurred primarily in open void regions of the shards and pumice. The last phase to fill these open void regions is opal. Montmorillonite is common in the groundmass. Fe-Ti oxide oxidation state $\left(C_{4}-C_{5}\right)$ (defined in Sec. VII) is not maximized due to the slightly reduced permeability of this sample.

The vitrophyre lies $100 \mathrm{ft}$ higher in the section (1292 ft). In thin section, all vitric components are dark brown, strongly compacted and welded, 
but largely unaltered. Incipient primary devitrification may have affected the vitrophyre, based on the appearance of small ( 5 micron) discrete spherulites sparsely dispersed in the pumice lapilli. En echelon fractures filled with diagenetic clays are present in the sample at $1292 \mathrm{ft}$, and perlitic cracks are pervasive in this sample. Fe-Ti oxides appear as primary unoxidized magnetite $\left(C_{1}\right)$ and ilmenite $\left(R_{1}\right)$.

The three remaining samples (1286, 1240, 1191) above the vitrophyre are densely welded, show vapor phase crystallization, and much later authigenic recrystallization. All are heavily fractured. The sample at $1286 \mathrm{ft}$ was devitrified during cooling. It shows primary spherulites of cristobalite and alkali feldspar transgressing all vitric boundaries. Vapor phase crystallization is indicated by lithophysae, and later diagenetic recrystallization is seen as small patches of interlocking quartz and alkali feldspar ir the groundmass. In sample 1286 diagenetic alteration is shown by veins filled with clinoptilolite, and the wall rock within a distance of $1 \mathrm{~mm}$ of the veins is altered to clinoptilolite and clays. Sample 1240 is similar to 1286 in that spherulites crosscut all vitric textures. Vapor phase crystallization is obseried as recrystallized central regions in shards showing axiolitic texture el sewhere, and as spherulites lining the border regions of pumice. Authigenic recrystaliization has progressed slightly further in this section, with a larger proportion of recrystallized quartz and alkali feldspar in the central regions of pumice. Quartz is observed filling veins of this sample. Sample 1191, from the highest sampled portion of the Topopah Spring Member, is very similar in texture to sample 1240 . The only difference is that opal (changing to chalcedony) may fill the central portions of both shards and pumice. A veinlet in 1191 shows altered and leached wall rock, but no fill is present. In all three densely welded samples, the Fe-Ti oxides are only slightly oxidized (average is $C_{3}$ ).

Phenocrysts in the Topopah Spring Nember are scarce. The predominant phases present are plagioclase, alkali feldspar, and Fe-Ti oxides. Rarely, embayed quartz and biotite are present. Altered pyroxene phenccrysts are present in trace amounts in samples 1392 and 1240.

The section of the Topopah Spring Member observed appears to be the lower portion of a single cooling unit. This is based on degree and sequence of welding and position of vapor phase crystallization. The progression upward in the Topopah Spring core is from slightly welded and zeolitized (1392 ft) to vitrophyre $(1292 \mathrm{ft})$ to densely melded $(1286,1240,1191 \mathrm{ft})$ and suggests that this is the lower portion of a single cooling unit. The densely welded samples all show evidence of primary devitrification, vapor-phase crystallization, and diagenetic alteration. The Fe-Ti oxides show oxidation states that are inversely proportional to the degree of we? ding (permeability) of the ash flow.

C. Tuffaceous Beds of Calico Hills

The Tuffaceous beds of Calico Hills are present in the USH-GI core from 1426 to $1802 \mathrm{ft}$, a thickness of $376 \mathrm{ft}$. Hand sample core descriptions by the U.S. Geological Survey (Spengler et âl., in preparation) identify 10 tuffaceous units in the core--primarily ash fiows, air falls, and bedded, reworked tuffs.

Four samples were thin sectioned. They were taken from the first, fifth, seventh, and tenth highest units. The lowest sample (1774 $\mathrm{ft}$ ) is an indurated reworked pumiceous air-fall tuff with a relatively high pher:ocryst content ( $25 \%$ by volume). The samples from the seventh (1639 ft) and fifth $(1561 \mathrm{ft})$ highest beds are pumiceous, zeolitic, phenocryst-poor ash flows and 
the highest sample $(1436 \mathrm{ft})$ is a zeolite-rich ash flow. All samples are nonwel ded.

The interlayered nature of the beds of Calico Hills, involving nonwelded ash flows, air falls, and reworked bedded tuffs, indicates temporally discrete eruptive events. All samples studied show marked zeolitization (clinoptilolite only). Zeolitization was aided by the extensive surface areas afforded by the pumice clasts and non- to slightly welded nature of the beds. The zeolitization process pseudomorphed original glass textures in all samples studied. Clinoptilolite commoniy forms massive, granular border regions in both shards and pumice, with late stage terminated crystals growing into void spaces. Clays rim pumice clasts and shards in all thin sections of the Calico Hills rocks. In addition, clays also mantle the bubble and tube structures of the pumice. Fe-Ti oxide microphenocrysts are oxidized to a high oxidation state in all samples of the $\mathrm{Calico}_{\mathrm{H}} \mathrm{Hills}$ section studied $\left(\mathrm{C}_{5}-\mathrm{C}_{7}\right)$. The high oxidation state is additional evidence of the high permeability of the nonwelded units examined.

Lithic fragments incorporated in the beds of Calico Hills are primarily clasts of older ash-flow tuffs, rhyolites, and bits of older pumice. They comprise 1 to $4 \%$ of the total volume and are similarl, zeolitized. Phenocrysts in the bedded tuffs of Calico Hills are principally embayed quartz, twinned plagioclase, zoned and unzoned sanidine, $\mathrm{Fe}-\mathrm{Ti}$ oxides, and minor biotite. Accessory phases are zircon and rutile. Vapor-phase crystallization was not observed in any of the zeolitized tuffs of the Calico Hills.

D. Prow Pass Member of Crater Flat Tuff

The Prow Pass Member of the Crater Flat Tuff extends from 1802 to $2173 \mathrm{ft}$ ( $371 \mathrm{ft}$ thick) in the USW-G1 core hole. Lithologic core descriptions (Spengler et al., in preparation) indicate six subdivisions of ash-flow tuff and a bedded, reworked air-fall tuff at the base.

Six samples were selected from the Prow Pass Member for thin-sectioning. One sample was obtained from the middle of the bedded, reworked air fall at $2166 \mathrm{ft}$. Five thin sections were obtained from the six ash-flow intervals. Two samples ( 1819 and $1854 \mathrm{ft}$ ) are from the uppermost ash-flow subdivision. The remaining three samples $(1823,1982$ and $2083 \mathrm{ft})$ are from the third, fourth and sixth highest intervals of the Prow Pass Member, respectively.

The lowest unit of the Prow Pass is a bedded, reworked air-fall tuff, which is nonwelded. This rock (sample 2166) is pseudomorphed by zeolites, the principal phases being clinoptilolite and mordenite. Pumice lapilli were the original dominant component, making up nearly $60 \%$ of the total volume. A11 lapilli are partly rounded, mantled by clay, and yet are structurally intact. The high oxidation state (indicated by Fe-Ti oxides) of the reworked air-fall tuff indicates high permeability to ground water.

The series of six ash-flow intervals of the Prow Pass Member probably represents a single cooling unit. Both the upper and lower parts of the Prow Pass Member's ash-flow section are only slightly welded. The central region exhibits partial to. moderate welding, with the most strongly welded region skewed toward the bottom (near $1982 \mathrm{ft}$ ), as is typical of a classic ash-flow cooling unit (Smith, 1960).

Both the upper (samples 1819 and 1854) and lower (sample 2083) ash-flow tuffs are slightly to partly welded and are strongly zeolitized. The principal zeolite is clinoptilolite. All original glass components in these three samples have been pseudomorphed by clinoptilolite, with minor traces of mordenite present in the lowest ash-flow sheet of the Prow Pass. The 
clinoptilolite is typically very fine grained, with terminated crystals apparent only in the larger voids. The $\mathrm{Fe}-\mathrm{Ti}$ oxides once again indicate a high oxidation state $\left(C_{4}-C_{7}\right.$ range, average $\left.C_{6}\right)$ for these permeable, slightly to partly welded tuffs.

The two remaining samples (1883 and 1982) of the Prow Pass Member, near the center of the cooling unit, record high original temperatures. The partly to moderately welded nature of the two samples, and the devitrification to anhydrous phases of the glass components, both indicate fairly hot temperatures. Sample 1982, which is moderately welded, shows primary devitrification to spherulites in buth the shards and pumice. Both shards and pumice have a border region of fibrous cristobalite and potassium feldspar intergrowths, and the central region is composed of spherulites of the same minerals. The moderate welding seen in sample 1982 reduced the permeability of this ash-flow sheet. The reduced permeability is reflected in the low oxidation state of the oxide phenocrysts $\left(C_{2}\right)$. The overlying ash-flow sheet, which contains sample 1883, is partly welded and shows an intermediate oxidation state $\left(C_{3}-C_{5}\right)$. The devitrification texture of shards in sample 1883 is primarily axiolitic. The devitrification textures for pumice are similar to the pumice in sample 1982. However, the central portions of the pumice are diagenetically recrystallized to interlocking masses of quartz and potassium feldspar. No vapor-phase crystallization is observed in the Prow Pass Member and may be attributed to insufficient temperature of emplac nent.

In summary, the ash-flow tuff of the Prow Pass Member cooled as a single cooling unit, and the types of crystallization (zeolitization and primary devitrification) can be correlated to the degree of welding. Ubiquitous phenocrysts of the Prow Pass are embayed quartz, twinned plagioclase, zoned and untwinned potassium feldspar and Fe-Ti oxides. Biotite is present in all samples except 2083. Once again, the oxidation state of the Fe-Ti oxides responds inversely to the degree of welding of the ash-flow units. Lithic fragments are primarily rhyolitic in composition in the Prow Pass. Pyroxene was not observed in thin section, in contrast to the core description (Spengler et al., in preparation).

E. Bull frog Member of Crater Flat Tuff

The Bullfrog Member of the Crater Flat Tuff is approximately $470 \mathrm{ft}$ thick, extending from 2179 to $2640 \mathrm{ft}$ in the USW-G1 hole. Hand sample descriptions separate the Bullfrog (BF) into two major tuff units, an upper unit (BF-I) that contains two lithologic intervals and a lower unit (BF-II) that contains five lithologic intervals. The two major units are separated by a $1 / 2$ - ft thick, bedded and reworked argillic tuff at $2317 \mathrm{ft}$. Lithologic differences that discriminate between the two major divisions are differing degrees of welding, and content of lithic fragments: BF-I is nonwelded with gray-brown volcanic lithic fragments only, whereas BF-II is slightly to moderately welded and contains red-brown mudstone lithics in addition to volcanic lithics.

Twelve thin sections were prepared from selected core samples of the Bullfrog. Four are from the lower purt of BF-I, two from the highest subdivision of $B F-I I$, four from the second highest subdivision of $B F-I I$, and two from the fourth highest subdivision of BF-II. The argillic tuff at $2317 \mathrm{ft}$ was not sampled.

Phenocryst phases throughout the Bullfrog Member of the Crater Flat Tuff are relatively constant. The phenocryst assemblage comprises quartz, alkali feldspar and plagioclase, with minor biotite, rhombohedral and cubic Fe-Ti 
oxides, and minor accessory phases. Quartz phenocrysts are typically anhedral and embayed, whereas feldspars are euhedral to subhedral. Plagioclase commonly shows twinning (albite and carlsbad) along with oscillatury zoning. Some alkali feldspars are untwinned. Biotite is the only ferromagnesian mineral identified in inost thin sections, even though hornblende appears to be common in hand samples, and abundant in thin section in the sample at $2555 \mathrm{ft}$. Fe-Ti oxides show secondary oxidation textures where the degree of oxidation appears to be inversely proportional to the original degree of welding in the tuffs. Another accessory phase in the Bullfrog is possibly rutile.

Bullfrog I is composed of two ash-flow tuffs that appear to have cooled as a single unit. A reworked argillic tuff forms the base of tinis unit, and the top is the Prow Pass Member of the Crater Flat Tuff. All four samples of Bullfrog I are nonwelded to slightly welded and later were heavily zeolitized.

Texturally, all four sections show structures (pumice and shards) that are intact and undeformed. Zeolites pseudomorph all forms of glass. Mordenite was identified by both x-ray diffraction and optical methods in samples 2290 , 2289, and 2233. Clays in the groundmass are slightly more abundant in the $B F-I$ samples than in BF-II. No vapor-phase crystallization was seen in BF-II. Gas phase effects, if present, werc masked by the pervasive diagenetic zeolitization in the BF-II samples.

Builfrog II is a single cooling unit that ranges from slightiy welded at the top and bottom (sampled at 2318 and $2600 \mathrm{ft}$, respectively) to moderately welded within its interior (sampled at $2436 \mathrm{ft}$ ). Maximum degree of welding (near $2436 \mathrm{ft}$ ) is denoted by deformation and flowage of shards in the groundmass within the hottest portion of the flow.

In the lowest portion of this unit (samples 2600 and 2555) primary glass is pseudomorphed by the zeolite minerals clinoptilolite and mordenite, and much of the primary void space is filled with these two phases (Fig. 3 ). Despite the degree of alteration, the morphologies of shards, pumice, and groundmass fragments are well preserved. This alteration probabiy reflects the absence or slight degree of welding, and hence original high permeability. These two samples also exhibit high oxidation states $\left(C_{6}-C_{7}\right)$ for $F e-T i$ oxide phenocrysts.

Upward from the zeolitized portion of BF-II, the degree of welding increases and the abundance of alteration products and the oxidation state of the oxides decreases. This effect appears to be controlled by the original reduced permeability of the partly to moderately welded units in the central and upper portions of BF-II. An interior body of devitrified tuffs in this cooling unit ranges from partly welded at top and bottom (samples 2363 and 2486, respectively) to moderately welded in the center (sample 2436). The mineralogy of the devitrification products consists mainly of alkali feldspar, quartz, and cristobalite with minor illite and smectite clays.

In the partly welded ash flow at $2486 \mathrm{ft}$, shards have axiolitic textures, and pumice lapilli are flattened, resulting in destruction of cheir original morphology. The pumice border regions are composed of fibrous intergrown sprays of cristobalite and alkali feldspar, which radiate toward the center of the pumice. The central regions are primarily spherulitic with minor interstitial quartz (Fig. 4). These textural features are considered to be caused by primary devitrification processes. Fron a sample at $2476 \mathrm{ft}$ to the top of BF-II (2318 ft), two textural features predominate in the vitric components that indicate vapor-phase crystallization. The shards no longer have axiolitic textures but are composed of granular or interlocking quartz and alkali feldspar grains that do not crosscut boundaries. Pumice clasts 


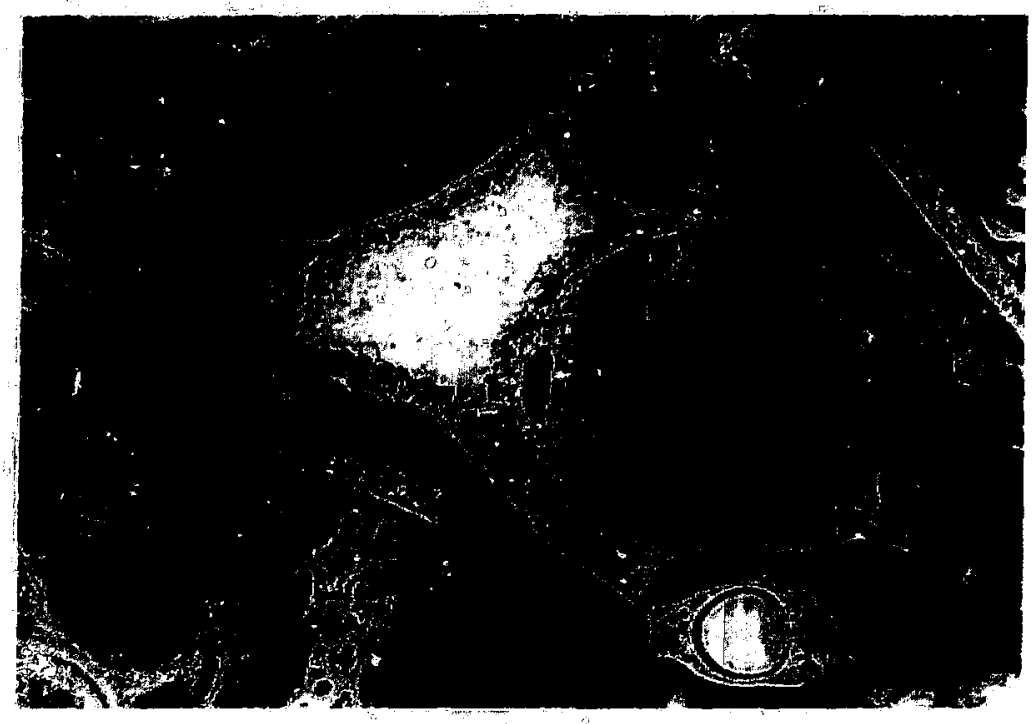

Fig. 3. Shard pseudomorphed by clinoptilolite. The white border is massive clinoptilolite, and the gray-appearing rim is terminated clinoptilo1ite. The large central white area is roid space. USH-G1, $2600 \mathrm{ft}$, plane light, $100 \times$ magnification.

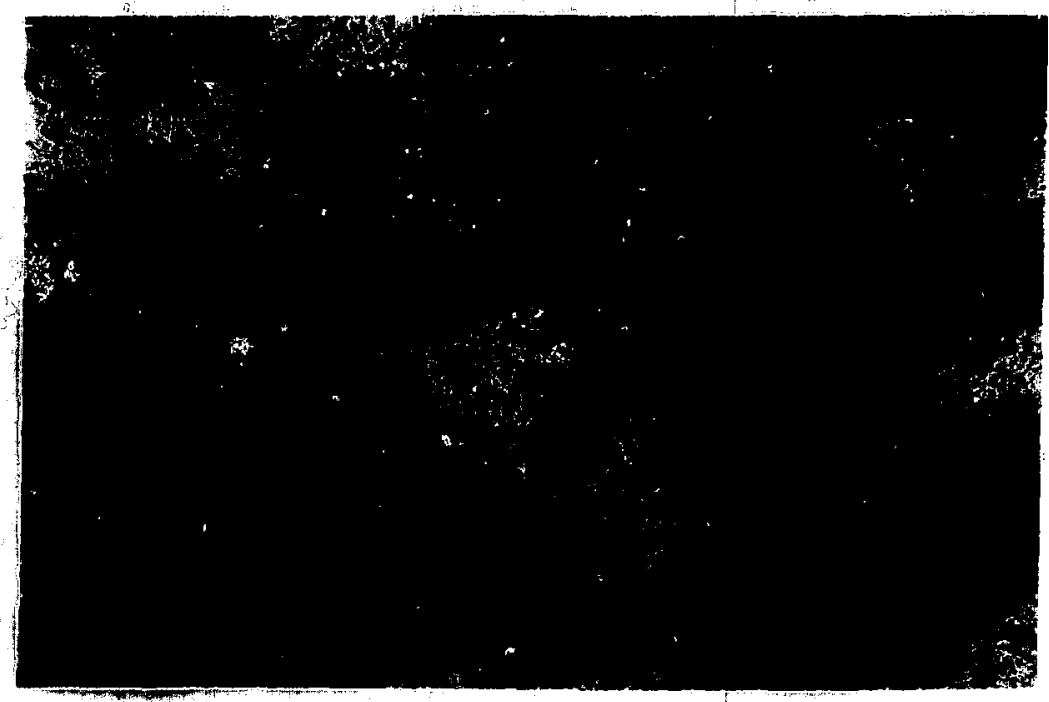

Fig. 4. Central portion of a pumice clast exhibiting spherulitic devitrification to cristobalite and alkali feldspar. USW-61, $2868 \mathrm{ft}$, plane light, $100 \times$ magnification. 
now have spherulites that line their border regions, and larger spherulites that completely fill the central regions. The groundmass of the samples commonly exhibits a vague granophyric crystallization texture (Smith, 1960). These textural and mineralogical criteria indicate that vapor phase crystallization has occurred from 2476 to $2318 \mathrm{ft}$.

Partially masking the vapor-phase effects is the overprint of diagenetic recrystallization. Two diagnostic criteria distinguish this recrystallization process. One, devitrified pumice clasts that have nucleated vapor-phase spherulites contain interior regions of relatively coarse-grained, interlocking quartz and alkali feldspar (Fig. 5). These recrystallized grains are surrounded by spherulitic zones along the borders of the pumice. Two, shards that have undergone several phases of devitrification (Lofgren, 1971) show a tendency for the recrystallized quartz and alkali feldspar grains to cross original shard boundaries. Recrystallization produces dendritic (feathery) growth of the two phases (quartz/alkali feldspar) from the interior of the shards outward into the groundmass in most cases (Fig. 6). Diagenetic recrystallization is present and sometimes dominant in samples from 2436 to $2318 \mathrm{ft}$, seen in the two textures discussed above, and also as groundmass granophyric texture.

F. Tram Tuff (Informal Basal Member of Crater Flat Tuff)

The Tram tuff is exposed in the USW-GI core from 2640 to $3558 \mathrm{ft}$, a total thickness of $918 \mathrm{ft}$. Log sample descriptions by Spengler et al. (in preparation) separate out five lithologic subdivisions within the Tram: a basal, bedded tuff and four subdivisions within ash-flow tuff. our petrographic work shows that the Tram can be subdivided into two easily recognized petrographic units: the upper Tram (2641 to $3083 \mathrm{ft})$, which coincides with the uppermost ash-flow subdivision of Spengler et al.. (in preparation) and the lower Tram ( 3083 to $3558 \mathrm{ft}$ ), which embraces the lower four subdivisions indicated in the same report. Criteria for recognition of these two petrographic units are relative abundance of 1 ithic fragments and the occurrence of allanite. Upper Tram lacks allanite and has a low content of 1ithic clasts (1 to $6 \%$ modal volume), whereas the lower Tram has both a hign 1 ithic content $(20$ to $35 \%$ modal volume) and allanite microphenocrysts. In a following section the lower Tram is further subdivided for purposes of discussion.

Fourteen thin ctions of the Tram were prepared from selected samples of the USW-G1 drill core. Eight sections are from the upper Tram unit, and the remaining six sections are from the lower Tram. Of these six thin sections, one each is from the upper two ash-flow intervals of the lower Tram, and the other four sections are from the lowest ash-flow subdivision in the lower Tram. The lowest lithologic unit of the lower Tram, a bedded, reworked tuff, was not sampled.

The upper Tram appears to be a single, largely devitrified cooling unit. Thin sections show an increase in degree of welding from slight at the top of the flow to dense near the bottom. No samples were taken from the bottom $82 \mathrm{ft}$ of the unit, below $3001 \mathrm{ft}$. The degree of welding should decrease back to siightly welded in that unsampled interval, if the upper Tram is a single cooling unit.

The two samples observed near the top of the upper Tram (2698 and 2641) are slightly to partly welded and extensively zeolitized. The only zeolite phase is clinoptilolite. Sherd boundaries in this portion of the upper Tram are deformed only near phenocrysts, and the pumice fragments are not deformed. zeolitization of this rock caused pseudomorphing of shards and pumice by 


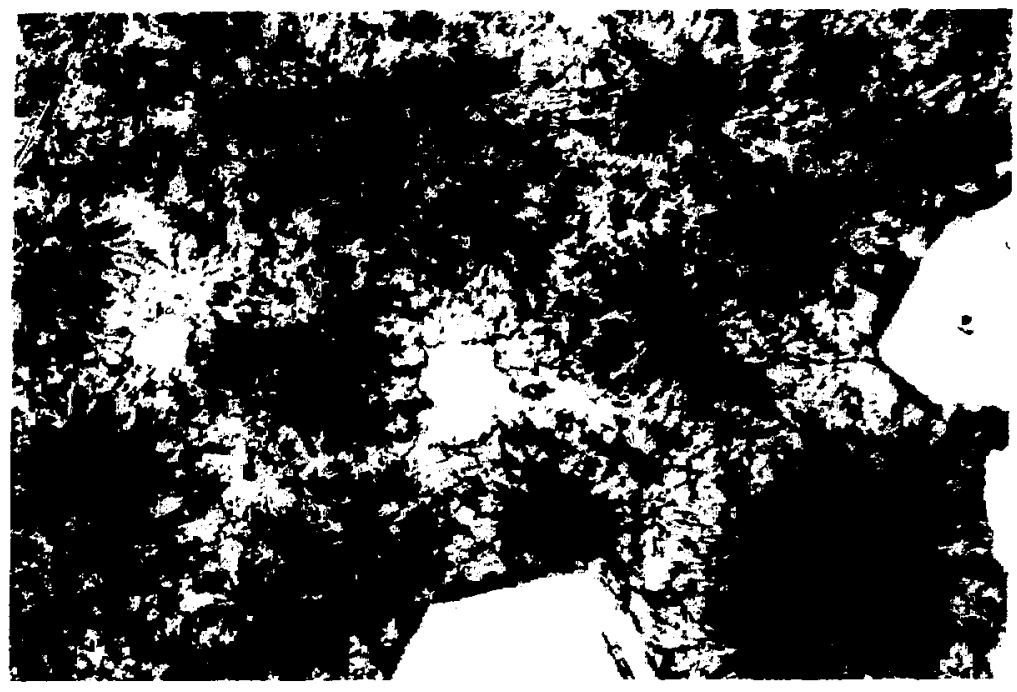

Fig. 5. Central portion of a pumice clast devitrified to spherulites of cristobalite and alkali feldspar. Note very light (low relief) regions of diagenetically recrystallized quartz and alkali feldspar at center and left center of photograph. Phenocrysts are present in this clast. USW-G1, $2901 \mathrm{ft}$, plane light, $50 \times$ magnification.

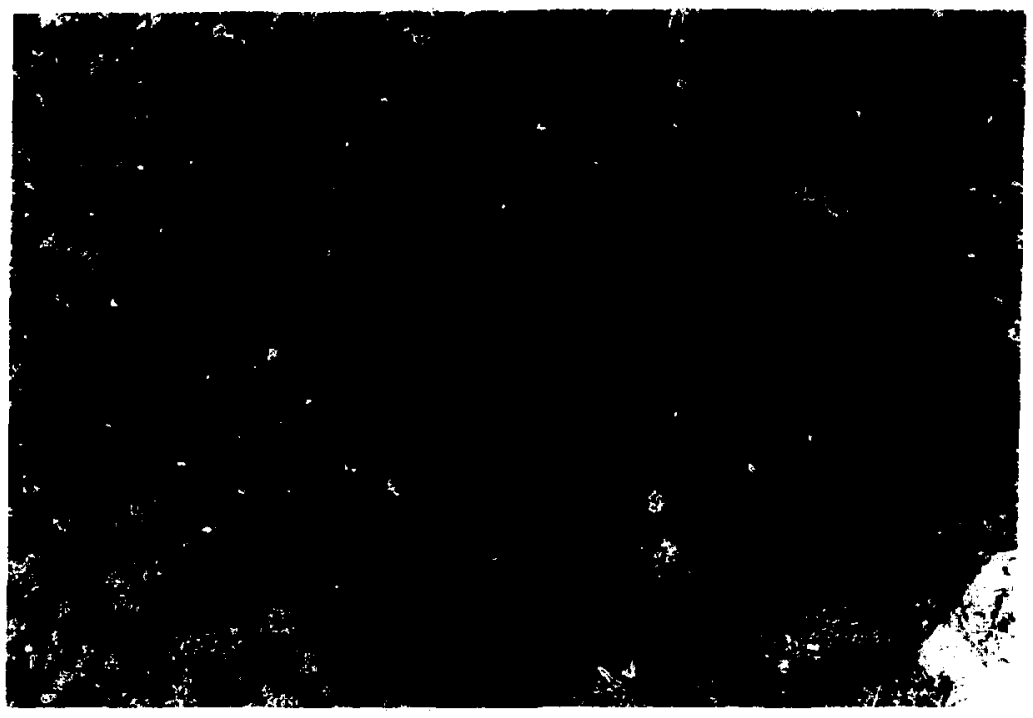

Fig. 6. Shards devitrified to cristobalite and alkali feldspar, and subsequently diagenetically recrystallized. Note feathery border regions of shards, indicative of diagenetic recrystallization. USW-GI, $2901 \mathrm{ft}$ plane light, $100 \mathrm{X}$ magnification. 
clinoptilolite, features that are also seen in ash flows of the lower Tram. Clinoptilolite also partially fills original void space. In the sample at $2698 \mathrm{ft}$, minor sprays of late-stage mordenite are seen in the centers of punice vugs. This mordenite was not detected in the $x$-ray diffraction patterns. As with other nonwelded to partly welded tuffs of the USW-Gl core, the oxides present in samples 2698 and 2641 are at their maximun oxidation states $\left(C_{5}-C_{7}\right)$.

The densely welded portion of the upper Tram was sampled at $3001 \mathrm{ft}$ and extends to at least $2868 \mathrm{ft}$ in the USW-G1 core, with the zone of maximum welding near $2901 \mathrm{ft}$. Evidence for this densely welded zone consists of shard deformation by plastic flow around phenocrysts and reduced Fe-Ti oxidation states (reduced permeability due to welding). Samples of the densely welded zone and up into the partly welded zone (sampled at $2790 \mathrm{ft}$ ) of the upper Tram show devitrification to quartz and alkali-feldspar and show evidence of vaporphase crystallization. Vapor-phase crystailization is considered to have occurred when shards begin to lose their axiolitic texture and recrystallize to patches of quartz and alkali feldspar that do not crosscut boundaries, and when pumice fragments show spherulites nucleating on the edges of the pumice lapilii and shards. Vapor-phase crystallization is evident from 2937 to $2790 \mathrm{ft}$. A later overprint of diagenetic recrystallization is prominent from 2901 to $2790 \mathrm{ft}$. In pumice fragments this produces sprawling masses of interlocking quartz and alkali feldspar with remnant spherulites along the borders of the pumice. In shards this diagenetic recrystallization produces dendritic (feathery) growths of quartz and alkali feldspar from imperfections along the edge of the shards outward into the groundmass. The sample taken at $3001 \mathrm{ft}$ shows devitrified shards that exhibit a remnant axiolitic texture of sanidine and cristobalite (now shanged to quartz). Pumice clasts contain abundan' $\mathrm{spherulites} \mathrm{that} \mathrm{do} \mathrm{not} \mathrm{crosscut} \mathrm{pumice} \mathrm{boundaries.} \mathrm{oxides} \mathrm{in} \mathrm{the}$ densely to partly welded portion of the upper Tram show only partial oxidation as a result of the reduced permeability of this part of the ash-flow unit.

The lower Tram is composed of ash-flow tuff subdivided into three intervals and a reworked tuff. Each subdivision may have had separate coo?ing histories. The lower contact of the lowest asi-flow interval (3218 to $3522 \mathrm{ft}$ ) is reported in the core $10 \mathrm{~g}$ as a fault, so a portion of the flow may be missing. This inferred fault is supported by an asymmetry in the cooling zones of the tuff. Sample 3500 is a slightly to partly welded tuff, whereas all other samples in the tuff $(3371,3321,3258)$ are nonwelded. Therefore, either the flow reverts to a nonwelded nature in the bottom $22 \mathrm{ft}$ (not sampled) to complete a symmetric cooling unit, or the bottom is absent.

This lowest ash-flow interval of the lower Tram shows the zonal change from clinoptilolite (zone II) to analcime (zone III) (Iijima, 1975, 1980; Iijima and Utada, 1971). The shards and pumice retain their original morphologies but are crystallized to zeolites. Near the top of the interval (sampled at $3258 \mathrm{ft}$ ) the zeolite phase is clinoptilolite only, whereas samples 3321 and 3371 contain approximately equal proportions of clinoptilolite and analcime, and sample 3500 contains only analcime as the zeolite phase. At $3371 \mathrm{ft}$ there is a vein of analcime $1 / 2-\mathrm{cm}$ wide. Typically, the zeolite phases infill all primary void spaces.

There are two different opaque minerals in this lowest ash-flow subdivision of the lower Tram, Fe-Ti oxides and pyrite. As opposed to most nonwelded to partly welded tuffs, in which the oxides are strongly oxidized, the cubic and rhombohedral phases in this interval are only marginally oxidized (predominately $C_{2}$ ). At $3258 \mathrm{ft}$, the oxides range from $C_{1}$ to 
$\hat{C}_{6}$ but are primarily $C_{2}$. Samples 3321 and 3371 contain only $C_{2}$ oxidation phases, and sample 3500 contains only sparse unaltered $\left(C_{1}\right)$ Fe-Ti oxides. In this ash-flow tuff, the oxidation state of the Fe-Ti oxides exhibits an inverse relationship to the abundance of pyrite. It is believed that the fluid that introduced the pyrite buffered the ambient fo2 in the tuff and that the composition of that fluid night have been influenced by the underlying altered Dacite flow breccia.

The second ash-flow unit of the lower Tram (3121 to $3218 \mathrm{ft})$ is nonwelded, zeolitized, and extensively oxidized. Clinoptilolite replaces all glass phases, but the shards and pumice show as obvious pseudomorphs. A11 original void space is partially to wholly filled by terminated clinoptilolite crystals. The $\mathrm{Fe}-\mathrm{Ti}$ oxides are extremely oxidized to $\mathrm{C}_{6}-\mathrm{C}_{7}$ stages, much more typical of nonwelded tuffs in the upper half of the USW-G1 core.

The highest ash-flow interval of the lower Tram (3083 to $3121 \mathrm{ft})$ is slightly to partiyy welded, zeolitized to clinoptilolite with minor analcime, and also shows a high-oxidation state $\left(c_{6}-c_{7}\right)$ for the oxides. The zeolitization of shards and pumice typically involves three stages: a border region of granular clinoptilolite, terminated clinoptilolite in vugs, and finally minor late-stage analcime filiings.

Phenocrysts of the upper and lower Tram are generally similar. In the lower Tram, they consist of embayed quartz, twinned plagioclase, zoned and unzoned potassium feldspar, bictite, Fe-Ti oxides, and allanite. The upper Tram lacks allanite. Hornblende and possibly pyroxene, identified in hand sample, were not seen in the Tram thin sections. This difference may in part be due to misidentification of blackened and slightly altered biotite in hand sample. Lithic fragments in the upper and lower Tram span the compositional spectrum from basaltic andesite to rhyolite, and in the lower Tram, most are al tered.

G. Dacite Flow: Breccia

In the USW-GI core, the Tram tuff rests upon a 388-ft sequence of lava flows, flow breccias and bedded tuffs called the Dacite flow breccia by Spengler et al. (in preparation). The Dacite flow breccia consists of 12 units; 8 are lava flow or breccia units that extend from 3558 to $3920 \mathrm{ft}$, below which are 4 units of tuff that will be described later in this section.

Four thin sections were prepared from the upper $362 \mathrm{ft}$ of the Dacite flow breccia. Sample 3598 is from the second highest flow breccia. Samples 3658 and 3706 are from the third highest flow breccia and sample 3850 is from the lava flow at the base of this section. All samples are partially to totally brecciated, have the same phenocryst phases, contain similar groundmass minerals, and with minor variations, contain the same vein-filling constituents. For convenience, these characteristics will be described from the base upward.

The lowest lava flow is disrupted by autobrecciation. Vesicles are common in this flow and have been filled by secondary minerals. Vesicle and veinlet fill commonly starts with a mantle of clays and oxides, then opal, then clinoptilolite and clays growing perpendicular to the walls, and finally the centers are filled with clinoptilolite, clays, and disseminated oxides. A veinlet is lined with clinoptilolite, then filled with large heulandite crystals, and finally with calcite. Calcite has also pseudomorphed large dolomite crystals in some veins. The groundmass of this flow is composed of quenched glass and microcrystalline material in approximately equal proportions. Both components are altered in part to montmorillonite. Phenocrysts identified are 
plagioclase with altered cores, clinopyroxene, orthopyroxene, hornblende, and Fe-Ti oxides. Pseudomorphs of serpentine, probably after olivine, were observed. All ferromagnesian phenocrysts have blackened rims. Fe-Ti oxides have a median oxidation state of $C_{3}$.

The breccias above the lava flow show only minor changes, mainly in groundmass textures and vein fill. Sections of samples 3706,3658 , and 3598 are all autoclastic breccias and contain the same phenocryst assemblage as samples 3850 , except that biackened ferromagnesian rims are increasingly 1 ess comon going up section within the Dacite flow breccia. In sample 3706 the groundmass has less clay alteration than 3850 and shows possible (relict) perlitic cracks. Vein filling in this sample is inuch more complex. The sequence from first to last phase of vein-filling minerals is clays and oxides, opal to chalcedony, clincpt.iolite, heulandite, and finally calcite.

Sample 3658 is from the same breccia as somple 3706 . Sample 3658 shows dominant clay alteration in the groundmass ind abundant perlitic cracks. Phenocrysts in this sample are the same as 3706 but frequently are glomeroporphyritic. Vein fill shows the same sequence as sample 3706 .

The highest flow breccia is represented by sample 3598. This rock is darker in color than the other samples and contains minor welded vitric tuff fragments, and small highly oxidized regions of rutile needles and hematite plates. Sample 3598 has the same phenocryst phases, groundmass mineralogy, texture, and vein-fill sequence, as sariple 3706.

Fe-Ti oxides of the Dacite flow breccia show the same phases and oxidation states. Both cubic and rhombohedral phases are present as phenocrysts, and at any appreciable distance from yeins, are almost completely primary $\left(c_{1}-c_{2}\right)$. The greater the proximity of the oxide grain to a vein, the higher its oxidation state. Grains adjacent to veins commonly show the maximum oxidation state $\left(C_{7}\right)$, but the median oxidation state for oxides in the Dacite flow breccia and in each sample is $C_{3}$. Apparently, fluids in the veins at one time must have had a high $\mathrm{f}_{2}$, for Fe-Ti oxides will oxidize to their maximum state readily. Even if a late, highly reducing fluid moved through the veins, the oxides would not revert back to their original state, because of the kinetic barriers of exsolution mechanics.

The bedded tuffs that lie at the base of the Dacite flow breccia, below the breccias and lava flows, are approximately 26-ft thick and divided into four units (Spengler et al., in preparation). Three are bedded reworked tuffs, and the third lowest unit is an air-fall tuff. A sample from the air-fall tuff at core depth $3940 \mathrm{ft}$ was sectioned. The sampled tuff is extensively aitered to montmorilionite, no shard or pumice outlines remain, and the sample is heavily fractured. Most of the fracture and void fill is clay, although minor analcime is present. Phenocrysts observed in the air-fall tuff include alkali feldspar, plagioclase, quartz, hornblende, and biotite.

H. Lithic-Rich Tuff

The Lithic-rich tuff lies beneath the Dacite flow breccia and extends from 3946 to $4940 \mathrm{ft}$ in the core, a total of $994 \mathrm{ft}$. The tuff is composed of two units: an upper ash-flow tuff (975-ft thick) and a lower bedded tuff $(19 \mathrm{ft})$. No samples mere taken from the bedded tuff.

Thin sections were made from 12 samples of the upper ash flow. Most of the samples are non- to slightly welded, the only exception being at $4805 \mathrm{ft}$ 
(slightly to partly welded). This ash flow may be a single cooling unit. Many authigenic alterations are recorded in this portion of the core; the core is easiest to describe from top to bottom.

All vitric components (shards and pumice lapilli) retain their original morphologies down to $4805 \mathrm{ft}$, at which point internal pumice clast morphology is obliterated by recrystallization to albite and sericite. Near the top of the ash flow most shards and pumice are pseudomorphed by analcime. This replacenient by analcime continues to $4341 \mathrm{ft}$, where albite laths appear, growing into large void regions of altered shards and pumice. The alteration to secondary albite is prevalent at $4400 \mathrm{ft}$, but from 4503 to $4805 \mathrm{ft}$ the growth of albite is less, such that terminated crystals are not apparent in open voids. The albitization then resumes as obvious crystals lining voids from $4805 \mathrm{ft}$ to the bottom of the ash flow. Based on first appearance of authigenic albite, the top of Zeolite Zone IV (Iijima, 1975) would be at about $4350 \mathrm{ft}$. Analcime continues as the major phase rep?acing both shards and pumice down to $4805 \mathrm{ft}$. At this depth, pumice is no longer pseudomorphed by analcime. Rather, albite, sericite, and quartz replace the pumice and obliterate its original morphology. Albite and sericite are oriented in two preferred directions in these pumice forms. Analcime remains a principal replacement phase of shards to the bottom of the ash flow.

Chlorite first appears as a replacement of clays at $3997 \mathrm{ft}$ and is limited to the tube walls of pumice fragments. Fractures in this sample also show some clays replaced by chlorite. All deeper samples in the ash flow show various amounts of chlorite after clays in shards, pumice and groundmass. Sample 4208 has chlorite mantling all lithic fragments and frequently replacing clays within the fragments. In sample 4503, many vein : by chlorite. From $4805 \mathrm{ft}$ to the bottom of the ash flow, chlorite is relatively widespread, filling some veinlets, voids, and partially replacing biotite phenocrysts.

Calcite is first seen at $4208 \mathrm{ft}$, where it fills a vein in the thin section. Down to $4400 \mathrm{ft}$ calcite is fairly pervasive as a late-stage filling of voids, vugs, and veins. From 4400 to $4700 \mathrm{ft}$ a relative depletion of calcite takes piace, but once again calcite becomes pervasive from $4700 \mathrm{ft}$ to the bottom of the ash flow, filling shard and pumice voids, replacing portions of phenocrysts, and forming veins.

Phenocrysts and microphenocrysts of the Lithic-rich tuff include plagioclase, alkali feldspar, biotite, Fe-Ti oxides, allanite, sphene, and quartz. Alteration of the feldspars changes through the ash-flow sheet. At the top of the unit, both feldspars are intact and coherent. Startinj at approximately $4200 \mathrm{ft}$, the rims of the alkali feldspars begin to look feathery or corroded, and plagioclase has sparse overgrowths. The cores of both are slightly mottled by al teration products. These trends continue down to $4600 \mathrm{ft}$, where some feldspar grains have more severely altered (rotted) cores. From this point to the bottom of the ash flow, all forms of feldspar alteration (overgrowths, rim and core degradation, disequilibrium features) continue to become more dominant.

The Fe-Ti oxides show a consistent oxidation state of $C_{5}-C_{6}$, regardless of the degree of welding of the tuff. The slight reduction from maximum oxidation may be attributed to either or both of the following two changes. First, the paleotemperature of $\sim 120^{\circ} \mathrm{C}$ may have kept the oxides from reaching their maximum oxidation state. Second, the $\mathrm{CO}_{2}$-rich fluid from wich the calcite deposited may have slightly buffered the ambient for of these tuffs. 
I. 01 der Bedded and Ash-Flow Tuffs

The OTder bedded and ash-flow tuffs of the USW-GI drill core extend from $4940 \mathrm{ft}$ to the bottom of the hole at $6000 \mathrm{ft}$. Drilling was ended at $6000 \mathrm{ft}$ without intercepting the bottom of the sequence. The $1060 \mathrm{ft}$ of core is composed of 42 lithologic subdivisiors, of wich 27 are ash-flow tuffs, 13 bedded/reworked tuffs, and 2 ash-fall units. Individual ash flows väry from nonwelded to densely welded, and initial description of the core indicates to us the possibility of up to 14 compound cooling units.

Sixteen samples were taken of the 01 der bedded and ash-flow tuffs for thin section study. Because this portion of the core is not yet formally classified, and because all major features of these rocks seen in thin section are obscured by diagenetic alteration, we have not attempted to establish the position of cooling-unit boundaries. Therefore, we describe the sequence as a whole, from top to bottom, without reference to the units listed by Spengler et al. (in preparation).

No definitive zeolite zone progression was observed in diagenetic shard or pumice alteration within this interval. Metastable phases are commonly present (for example, analcime coexisting with authigenic albite), and in some samples metastable minerals are still the dominant phase. Shards are commonly altered to produce four major textural and/or mineralogical assemblages: (1) analcime completely pseudomorphs shards, (2) albite stringers surround a central region of massive analcime (Fig. 7), (3) granular interlocking albite with or without quartz grains replaces shards, and (4) albite laths grow from the outer edge of shards, and central voids are filled with albite and analcime. Most samples have approximately equal proportions of these four assemblages. Exceptions are that analcime pseudomorphs (1) are the dominant shard al teration at 5126,5212,5412,5679, and $5947 \mathrm{ft}$; and albite laths with minor analcime (4) are dominant in samples 5026, 5093, and 5311.

Five dominant textural and/or mineralogical assemblages result from the alteration and replacement of pumice lapilli: (1) analcime and chlorite respectively fill and pseudomorph pumice tubes and tube walls (Fig. 8); (2) analcime and chlorite with minor albite occur along bubble-tube walls and along outer pumice edges; (3) intergrown albite, sericite and minor analcime and chlorite pseudomorph pumice fragments; (4) albite and sericite pseudomorph pumice, with albite and interstitial analcime infilling vugs; and (5) oriented albite and sericite obliterate all original pumice textures. All five assemblages of altered pumice are commonly seen in all sections but in various proportions. Stage five alteration of pumice is dominant, however, in samples $4998, .5026,5093,5311,5348,5847$, and 5912, and stage four is dominant at $5126 \mathrm{ft}$. A dominance of stage five pumice alteration may be correlated with the non- to slightly welded ash-flow sheets.

Groundnass mineralogy is typically represented by various proportions of analcime, authigenic albite, quartz, clays, chlorite, sericite, and Fe-Ti oxides. Fine-grained textures are prevalent from 4998 to $5296 \mathrm{ft}$. From 5296 to $6000 \mathrm{ft}$, recrystallization of the groundmass produces larger grains that encroach on shard and pumice lapilli boundaries. Lithic fragments incorporated in the tuffs are primarily devitrified rhyolites (especially spherulites) from 5000 to $5500 \mathrm{ft}$; the lower half of the tuff unit has lava lithic fragments that range from basaltic to rhyolitic compositions. Yery late-stage phases that commonly fill veins, voids, and vugs are calcite and chlorite. Throughout the tuffs, calcite is a very pervasive, late-stage phase but is less abundant at 4998,5212 , and $5311 \mathrm{ft}$. 


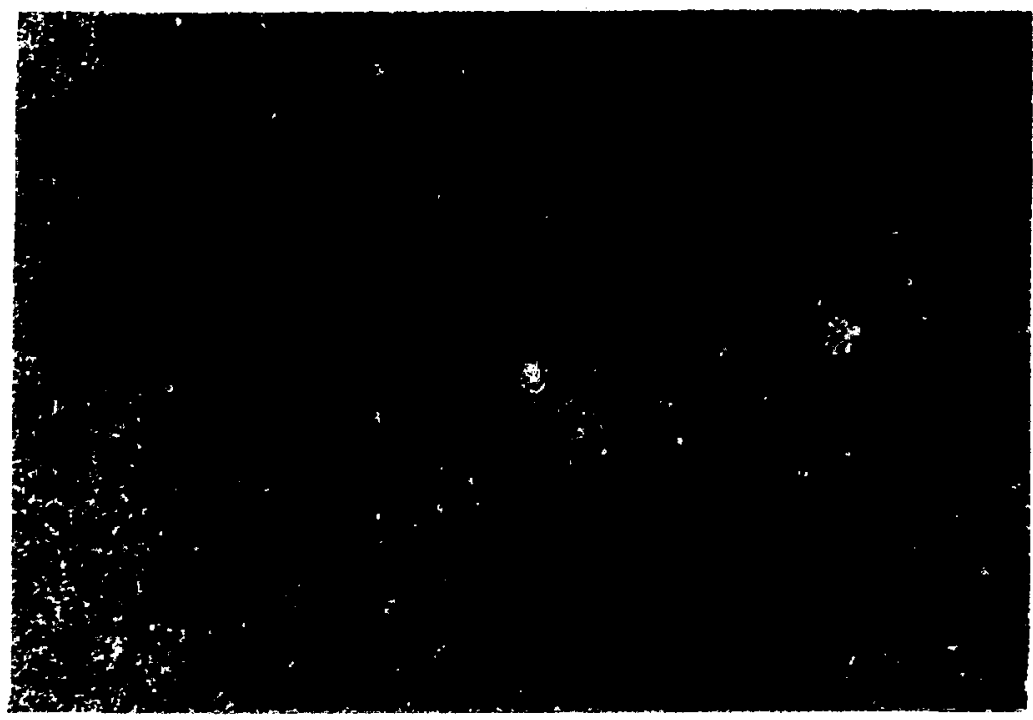

Fig. 7. Shard pseudomorphed by analcime. Note smail albite crystals (higher refractive index) along border of shard. USW-G1, $5167 \mathrm{ft}$, plane light, $200 \times$ magnification.

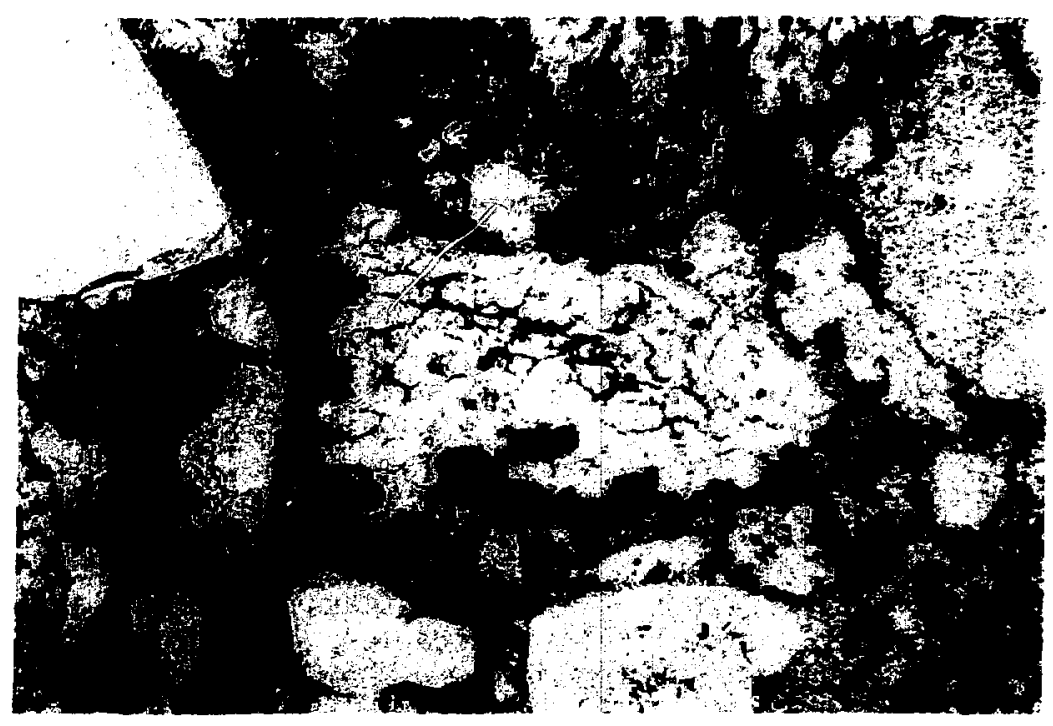

Fig. 8. Pumice clast pseudomorphed by analcime. Note that bubble walls are intact. USW-G1, $5296 \mathrm{ft}, \mathrm{plane}$ light, $50 \times$ magnification. 
Phenocrysts of the 01 der bedded and ash-flow tuffs include quartz, alkali feldspar, plagioclase, biotite, Fe-Ti oxides, sphene, allanite and zircon. The plagioclase is severely altered, especially shown by extensive degradation of its cores. At the top of the section (4998 ft), some feldspars have feathery boundaries or albite overgrowths and "wormy" cores. This degradation continues until at $5300 \mathrm{ft}$ where such features are common to all plagioclase phenocrysts. In addition, microperthitic and graphic perthitic textures are first observed at $5296 \mathrm{ft}$. From $5300 \mathrm{ft}$ to the bottom of the core, feldspar degradation continues unabated, exhibited by extensive rim destruction, albite overgrowths, wormy or degraded cores, and replacement by sericitic alteration of the plagioclase component in perthites. Finally, at 5847 and $5947 \mathrm{ft}$, only albite cvergrowths are common around a core composed of a'bite lamellae separated by sericite and quartz, or by void space (Fig. 9).

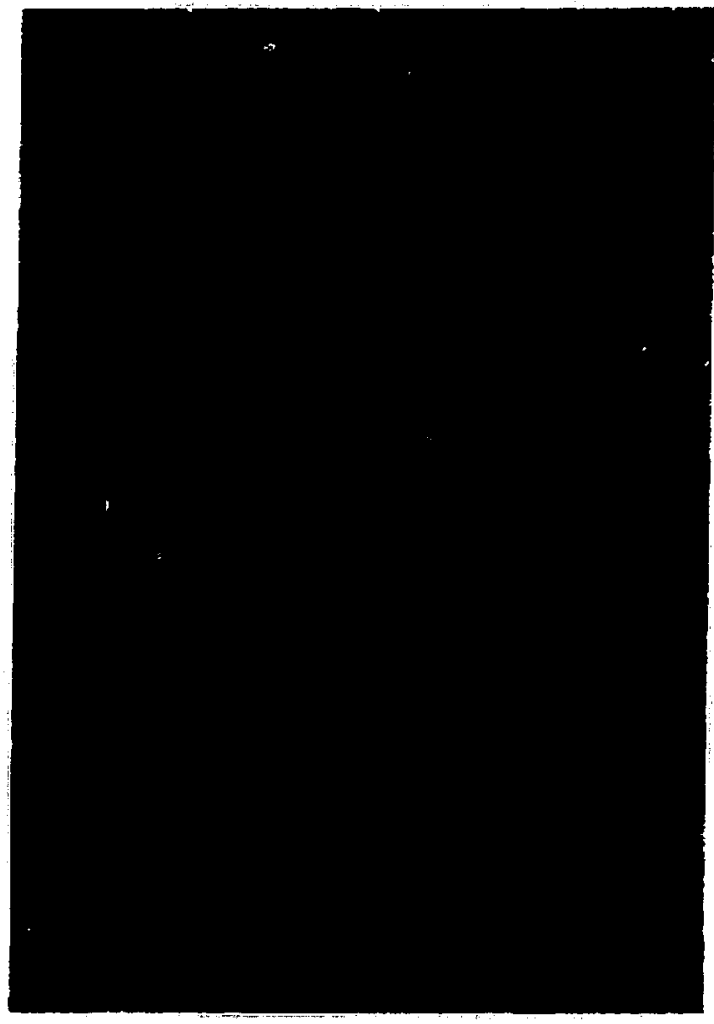

Fig. 9. Altered feldspar phenocryst mantled by aibite overgrowth. Phenocryst replaced by albite, sericite, and possibly analcime or quartz. USW-G1, $5847 \mathrm{ft}$, plane light, $200 \times$ magnification.
Fe-Ti oxides appear only as accessory microphenocrysts ( 1 to $2 \%$ ) in the upper half of these tuffs. From $5500 \mathrm{ft}$ downward, these opaque minerais constitute $30 \%$ of the total phenocryst assemblage and 4 to $7 \%$ of the modal volume. The oxidation state of the Fe-Ti oxides no longer shows a strict inverse relationship to the degree of welding (permeability) of the tuff. In many cases, the oxidation state of the oxides is reduced relative to specimens from higher in the USW-G1 core. It is not uncommon to see primary, unoxidized opaque minerais in nonwelded sheets (for example, $5679 \mathrm{ft}$ ). The ambient for of these tuff sheets has probably been buffered to a great degree by the $\mathrm{CO}_{2}$-rich fluids that have deposited the omnipresent calcite. The correlation is readily apparent in samples such as 5947, 5637, 5412, and 5296, where pervasive calcite is seen in conjunction with Fe-Ti oxides that are only slightly oxidized.

\section{A SEARCH FOR QUANTITATIVE} FACTORS TO CHARACTERIZE THE PETROLOGY OF ALTERED TUFFS

\section{A. Foreword}

General petrographic characteristics of the USW-G1 core have been presented in the section 
above. In this part we recount some progress in an effort (still unfinished) to find definitive and easily measured parameters that can help to quantify and evaluate correlation of tuff formations or members, and also can assist in determining the origin and history of individual tuff units. (For example, have the constituents of a unit logged as "bedded tuff" been formed from only the debris of a single eruption cycle, or does the unit contain material reworked from recognizable older units in the stratigraphic section?)

Quantitative mineralogy (referred to as the mode) of a rock is generally obtained by careful point counting of the minerals in thin section (or for coarse-grained rocks such as granite and gneiss, counting can be done on a polished slab stained to bring out certain minerals). Point counts of tuffs that are composed only of unal tered glass, phenocrysts, and microlites are easily made, but in tuffs such as those from USW-G1 where some or all of the glass shards and pumice lapilli have been transformed into clays, zeolites, silica minerals, and other alteration products, point counts are seldom satisfactory. The fine-grained and interwoven textures of the alteration minerals, and inability to determine many minerals under the microscope in such small grains, cause gross operator variance when point counting is tried. Staining is of little or no help.

$X$-ray diffraction is an inexpensive and quick method of determining many of the zeolite and clay phases and is of real value in addressing such questions as zeolite zoning (I ijima, 1975; Iijima and Utada, 1971; Iijima and Ohwa, 1980). The silica minerals (opal vs cristobalite, and cilalcedony vs quartz), however, are difficult or impossible to distinguish by $x$-ray diffraction, and similar difficulties arise in discriminating chlorites from clay minerals. Crude and inaccurate "guesstimates" (incorrectly listed as modes in some reports) can be made of the relative abundances of certain phases identified by $x$ ray. Even if inaccurate, these have proved useful in some $k$ inds of work.

B. Phenocryst Phases and Lithic Clasts

In searching for quantitative and reproducible relations that can be obtained from a thin section of tuff, we reasoned that phenocryst phases and lithic clasts can be point counted accurately, and the alteration products of volcanic glass could be grouped together as matrix. Phenocryst phases, even plagioclase, are much less susceptible to diagenetic alteration than glass shards or pumice lapilli, and the outlines of phenocrysts are generally visible even after pseudomorphing by al teration minerals. Lithic clasts are al so easy to recognize, even when al tered.

Therefore the proportions of lithic fragments, phenocrysts, and matrix were determined from a count of 500 points, or more, for each thin section. The proportions of phenocrysts, lithic fragments, and matrix from tuffs are plotted on ternary diagrams similar to those used by Cook (1965). Excellent work of this kind on tuffaceous rocks from the Nevada Test Site by Byers, et al. (1976) and by Quiniivan and Byers (1977) shows that relative proportions of different phenocryst minerals are characteristic of certain tuff units and aid in their correlation. However, our early attempts to duplicate their results for total phenocrysts of quartz, alkali feldspar, and plagioclase in thin sections from the USW-G1 core were only marginally successful. The reason was operator variance, which is a problem inherent for point counting of fine-grained rocks, and is caused by the large number of decisions that must be made at grain boundaries, nius the difficulty of deciding on the identification of similar appearir- rinerais in small grains. This problem 
was successfully circumvented by identifying and using only those phenocrysts having the largest areas within a thin section. To assure reliable identifications in our early efforts, such phenocrysts also were identified by energy-dispersive microprobe analysis. Areas determined by point count were then used to estimate the relative proportions for those felsic phenocrysts having the largest areas in the thin section. Thirty to forty large phenocrysts within a standard thin section (500-700 $\mathrm{mm}^{2}$ area) provided a statistically significant population, and their relative proportions did not vary appreciably when the number of such phenocrysts was increased up to 120. These findings were tested for six thin sections representing three different stratigraphic units, and having total felsic phenocryst contents from 2.4 to $14.6 \%$ of the total rock. The results indicate that a much more reproducible and characteristic value can be determined for felsic phenocryst proportions using only 30 to 40 phenocrysts showing the largest areas in the thin section than by point counting the entire thin section. In this report relative proportions for those felsic phenocrysts having the largest areas in thin section are plotted for samples from three different stratigraphic units on ternary diagrams like those used by Byers, et al. (1958).

It is recognized that reiative proportions of phenocrysts of all sizes may differ considerably from proportions of selected phenocrysts having the largest areas in thin section. The Tram tuff characteristically contains much higher proportions of quartz and lower proportions of plagioclase among those feisic phenocrysts having the largest areas than for those of all areas (Table II). A sample of Bullfrog Member included for comparison shows no such difference (Table II). This comparison brought out and emphasized that quartz phenocrysts have larger areas in thin section compared to plagioclase for the Tram, but this does not occur for the Bullfrog (Fig. 10). It is important to recognize that the variation in relative portions of felsic phenocrysts with area in thin section is in itself a characteristic petrographic feature for each stratigraphic unit. The difference for the Tram is due to exceptionally large quartz phenocrysts associated with abundant small plagioclase phenocrysts.

Compositions of the phenocrysts are also highly definitive for units of the USW-G1 core and are readily determined by microprobe analysis. Except for a few samples, we found that dominant values and ranges for important compositional components do not vary throughout an ash-flow sequence and can be recognized in histograms. Such histograms show very distinct mineral compositions that are valuable correlative tools for some units, or similarities among. mineral compositions that define petrographic suites for other units.

Eight large phenocrysts, each of alkali feldspar and plagioclase in each thin section, were analyzed at their cores by electron microprobe for $\mathrm{Na}, \mathrm{Al}$, $\mathrm{Si}, \mathrm{K}, \mathrm{Ca}, \mathrm{Fe}$, and $\mathrm{Ba}$. Three phenocrysts each were also analyzed at the rim and halfway between the core and rim (midrange). A pyroxene standard was employed for iron analyses and feldspar standards were used for all other elements. Histograms that show the variation in potassium (orthoclase molecular end member) and bariun (celsian molecular end member) in alkali feldspar, and in calcium (anorthite molecular end member) in plagioclase are provided for each stratigraphic unit. Alkali feldspar and plagioclase have characteristic dominant compositions and compositional ranges that rarely differ within a continuous ash-flow sequence. End member compositions are also included in histograms for a few plagioclase phenocrysts in lithic fragnents; these end member contents can be compared with those for plagioclase in the matrix of the rock to evaluate the possible presence of plagioclase xenocrysts derived from the lithic fragments. 
COMPARATIVE PROPORTIONS OF FELSIC PHENOCRYSTS OF ALL SIZES VS THOSE WITH THE LARGEST AREAS IN THIN SECTION FOR THE TRAM AND BULLFROG TUFFS

Relative Felsic Phenocryst Proportions, (\%)

All Sizes

\begin{tabular}{|c|c|c|c|c|c|c|c|c|}
\hline $\begin{array}{l}\text { Sample } \\
\text { Depth } \\
\text { (ft) }\end{array}$ & Unit & 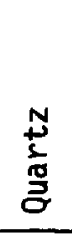 & 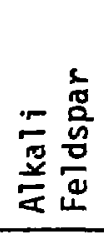 & 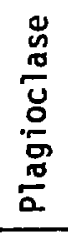 & $\begin{array}{l}\mathbf{N} \\
\mathbf{N} \\
\mathbf{2} \\
\mathbf{3} \\
\end{array}$ & 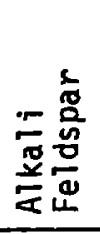 & 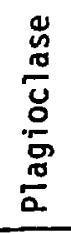 & 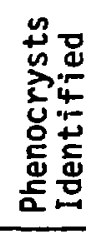 \\
\hline 3258 & middle Tram & 33 & 33 & 34 & 61 & 26 & 13 & 29 \\
\hline 3196 & middle Tram & 29 & 29 & 42 & 60 & 18 & 22 & 29 \\
\hline 2868 & upper Tram & 40 & 35 & 25 & 51 & 40 & 9 & 40 \\
\hline 2555 & lower Bullfrog & 7 & 45 & 48 & 5 & 50 & 45 & 36 \\
\hline
\end{tabular}

Mafic phenocrysts found in thin sections of USW-G1 core are biotite, hornblende, and pyroxene; olivine is not present. No attempt was made to identify those mafic phenocrysts (pseudomorphs) that had completely altered optical properties and chemical compositions. Only biotite was found in most samples of tuff. Several grains of any mafic phenocryst type present in each sample were analyzed by electron microprobe for $\mathrm{Na}, \mathrm{Mg}, \mathrm{Al}, \mathrm{Si}, \mathrm{K}, \mathrm{Ca}, \mathrm{Ti}, \mathrm{Fe}$, and $\mathrm{Ba}$. A pyroxene standard was employed for $\mathrm{Mg}$, $\mathrm{Ti}$, and $\mathrm{Fe}$ analyses and feldspar standards were employed for all other elements. Core, midrange, and rim analyses for numerous mafic phenocrysts indicate no systematic normal zoning. Histograms that show the magnesium and iron contents of mafic phenocrysts $[\mathrm{Mg} /(\mathrm{Mg}+\mathrm{Fe})$ molecular ratio] and barium contents of biotite are provided for each stratigraphic unit. Biotite compositions rarely differ appreciably within a continuous ash-flow sequence. Magnesium, iron, and barium contents are also included in histograms for a few biotite and hornblende phenocrysts in 1ithic fragments; these elemental contents can be compared with those for biotite and hornblende in the matrix of the rock to evaluate the possible presence of xenocrysts derived from the lithic fragnents. Apatite, zircon, allanite, and sphene are the most abundant primary accessory minerals in the USW-GI core. Such minerals were identified by their optical properties and by energy dispersive electron microprobe analysis. Most of the apatite and zircon forms inclusions in biotite, oxides, and some plagioclase, but allanite and sphene occur mostly as discrete grains, not as inclusions. The abundances of these accessory minerals vary systematically within stratigraphic units, indicating that the accessory minerals could aid detailed correlations of particular stratigraphic intervals. Allanite and sphene abundances in thin section and distinctive apatite and zircon abundances are included for each unit in the following section. 

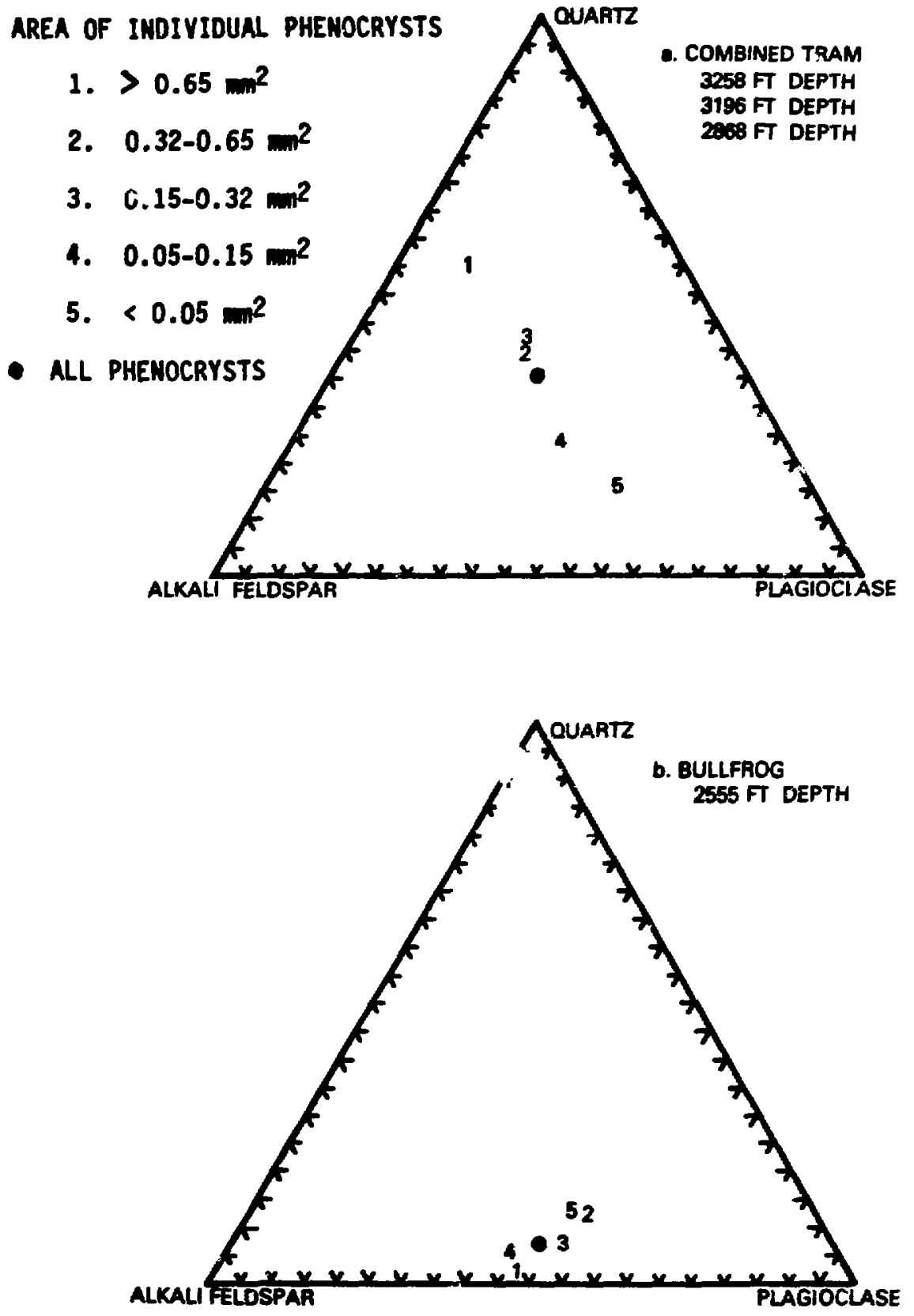

Fig. 10. Relative proportions of felsic phenocrysts as a function of area in thin section for the Tram and Bullfrog Tuffs. 
A large amount of data has accumulated that is still in process of evaluation, and not yet ready to present at this time. As illustrative examples, we record below the results from investigation of the phenocrysts from three adjacent stratigraphic units, which extend from 1802 to $3558 \mathrm{ft}$ in the drill core: the Prow Pass Member of the Crater Flat Tuff, the Bullfrog Member of the Crater Flat Tuff, and the Tram tuff.

\section{Stratigraphic Units Between 1802-3558-Ft Depths}

1. Prow Pass Member of Crater Flat Tuff. The proportions of matrix, lithic fragments, and phenocrysts are shown in Fig. 11 for the Prow Pass Member. Lithic fragments comprise $<2 \%$ of the rock and phenocrysts 8 to $18 \%$.

Relative proportions of those felsic phenocrysts having the largest areas in thin section show little variation throughout the ash-flow tuff of the unit (1819- to 2083-ft depth, Fig. 12) and average about $12 \%$ for quartz and $44 \%$ each for alkali feldspar and plagioclase. The felsic phenocryst proportions for bedded/reworked tuff (2166-ft depth, Fig. 12), however, differ distinctly from these values. Alkali feldspar and plagioclase phenocrysts having areas in thin section $>1.0 \mathrm{~mm}^{2}$ are commion in the ash-flow tuff but not in the bedded/reworked tuff; maximum areas in thin seçtion for the Prow Pass Member are $3.4 \mathrm{~mm}^{2}$ for alkali feldspar and $2.7 \mathrm{~mm}^{2}$ for plagioclase. Quartz phenocrysts seld dom have an area in thin section $>1.0 \mathrm{~mm}^{2}$; their maximum area is $1.4 \mathrm{~mm}^{2}$.

The compositions of both alkali feldspar and plagioclase also differ appreciably between ash-flow tuff and bedded/reworked tuff of the Prow Pass Member. The median orthoclase $\langle 0 r)+$ celsian $\left(C_{n}\right)$ end member content is $53 \mathrm{mo} 1 \%$ and the median $\mathrm{BaO}$ content is $<0.1 \mathrm{wt} \%$ for ash-Flow tuff; the median $\mathrm{Or}+\mathrm{Cn}$ is $60 \mathrm{~mol} \%$ and the median $\mathrm{BaO}$ is $0.4 \mathrm{wt} \%$ for the bedded/reworked tuff (Fig. 13). The dominant anorthite (An) end member content of plagioclase is $11 \mathrm{~mol} \%$ for ash-flow tuff and $17 \mathrm{~mol} \%$ for the bedded/reworked tuff. Compositional ranges are relatively narrow for both alkali feldspar and plagioclase throughout the Prow Pass (Fig. 13). The dominant compositions and compositional ranges for both alkali feldspar and plagioclase of the bedded/ reworked tuff are strikingly similar to those of the underlying Bullfrog Member and suggest that a portion of this unit consists of reworked Bullfrog Member.

Mafic phenocrysts consist solely of biotite (maximum single-crystal area in thin section of $0.25 \mathrm{~mm}^{2}$ ). Many biotite phenocrysts are severely altered throughout the Prow Pass and all have been al tered to a clay-oxide assemblage at sample depths 1982 and $2083 \mathrm{ft}$. Zircon and apatite inclusions in biotite are uncormon in the Prow Pass Member. Biotites have similar compositions throughout the Prow Pass and all analyses were used for Fig. 14; they are relatively magnesium-poor (median molecular $\mathrm{Mg} /(\mathrm{Mg}+\mathrm{Fe})=0.42$ ) but bariumrich (median $\mathrm{BaO}=1.6 \mathrm{wt} \%$ ).

Allanite, with a maximum single-crystal area in thin section of $0.02 \mathrm{~mm}^{2}$, was found only at 2083-ft depth. Sphene is absent from the Prow Pass Member.

2. Bullfrog Member of Crater Flat Tuff. The proportions of matrix, 1ithic fragments, and phenocrysts are shown in Fig. 15 for the Bullfrog Member. In most samples lithic fragments make up $<3 \%$ of the rock; phenocrysts comprise 8 to $12 \%$ below $2420-\mathrm{ft}$ depth and 15 to $27 \%$ above this depth. 

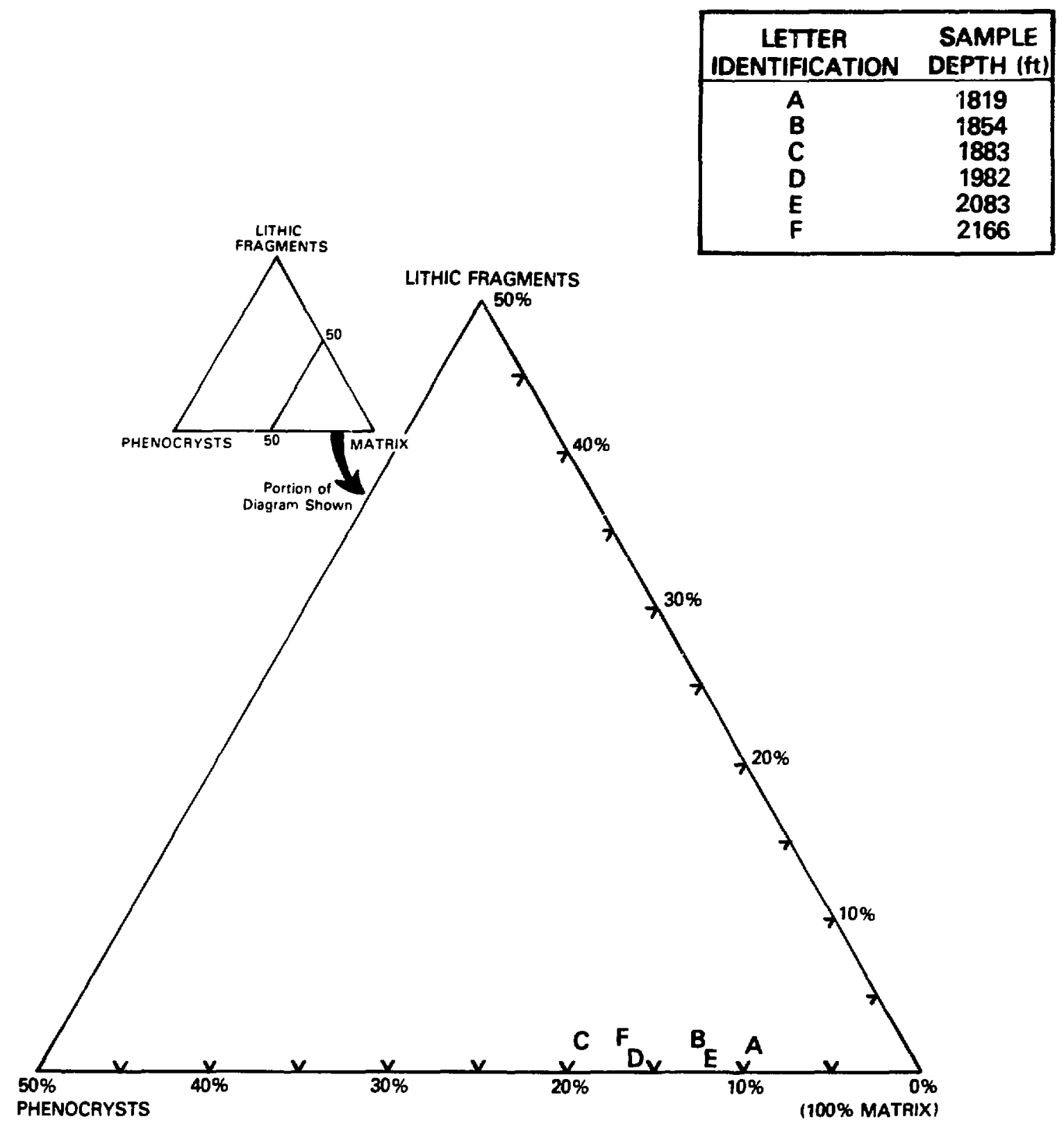

Fig. 11. Proportions of lithic fragments, phenocrysts, and matrix in thin sections of Prow Pass Member. 

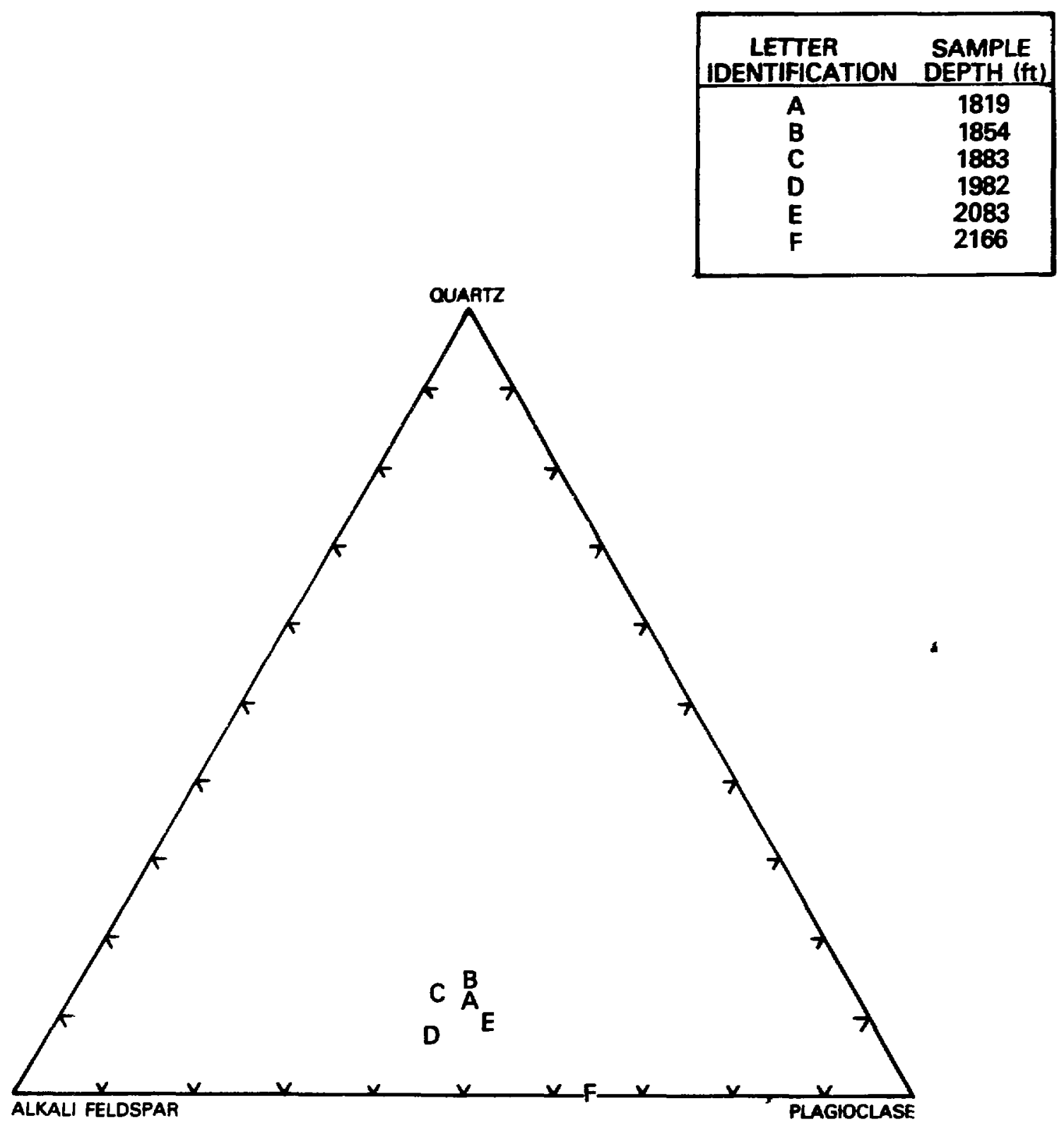

Fig. 12. Relative proportions of those felsic phenocrysts having the largest arrass in thin section for Prow Pass Member. 


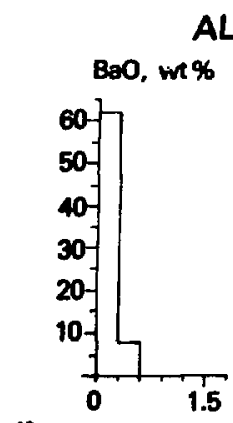

ALKALI FELDSPAR

$\mathrm{O}+\mathrm{Cn}$, MOL\%

PLAGIOCLASE

An, MOL\%
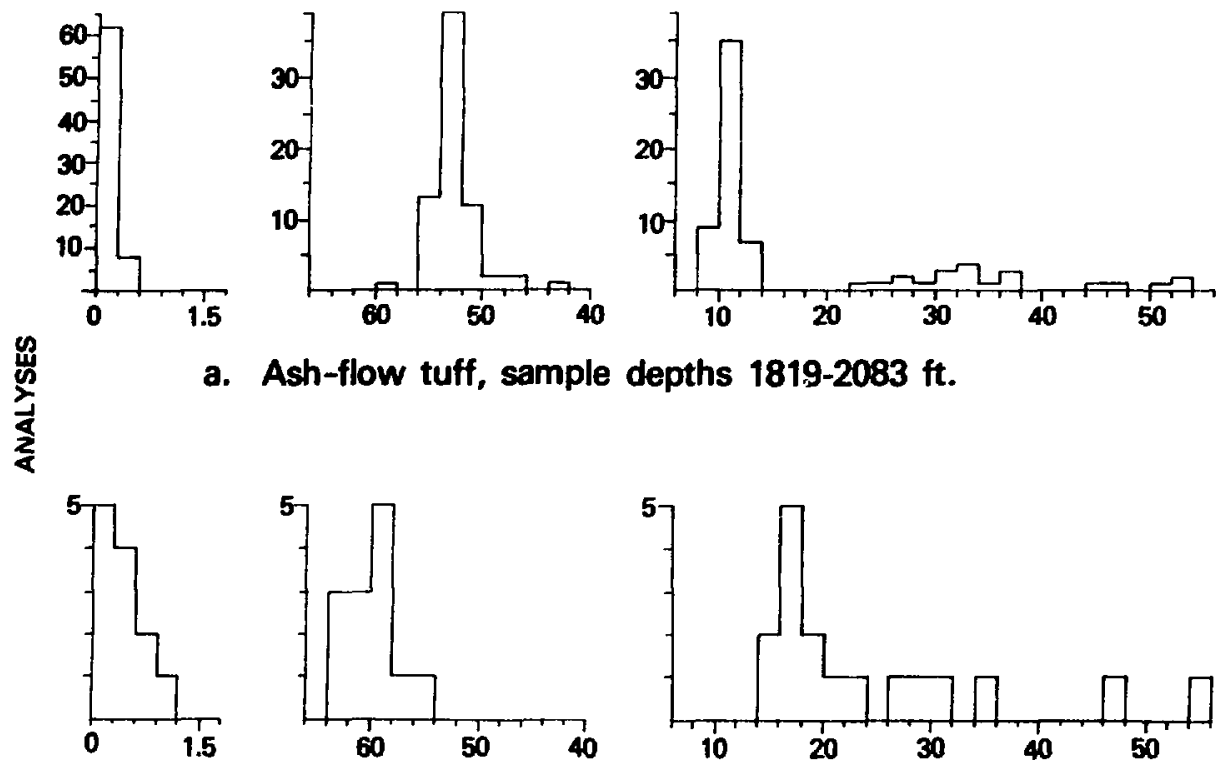

a. Ash-flow tuff, sample depths $1819-2083 \mathrm{ft}$.
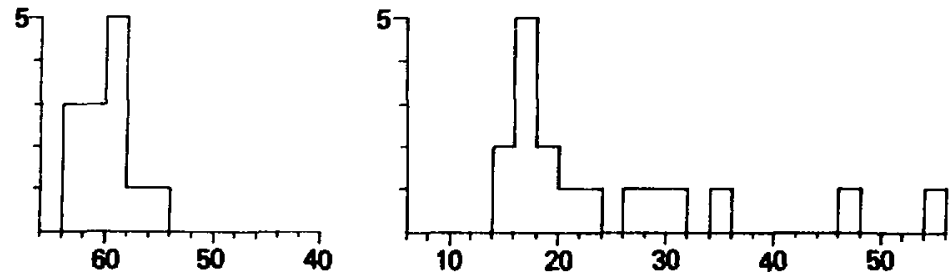

b. Bedded/reworked tuff, sample depth $2166 \mathrm{ft}$.

Fig. 13. Histograms of wt\% BaO and mol $\%$ orthoclase + celsian in alkali feldspar, and $m 01 \%$ anorthite in plagioclase of Prow Pass Member. These components were obtained from complete chemical analysis by electron microprobe.

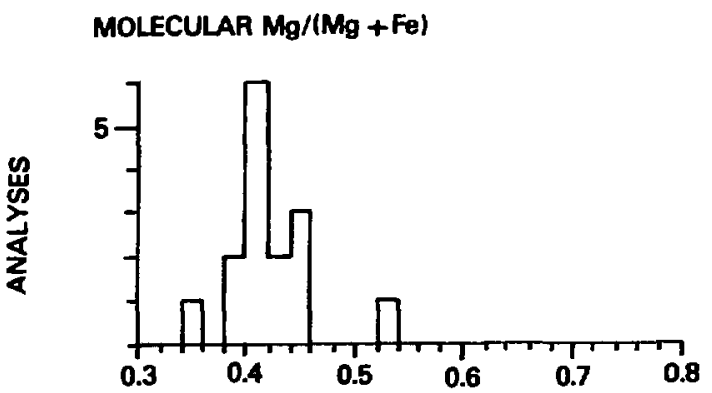

BaO,wt \%

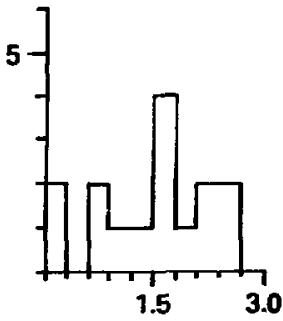

Fig. 14. Histograms of molecular $\mathrm{Mg} /(\mathrm{Mg}+\mathrm{Fe})$ and wt\% $\mathrm{BaO}$ in biotite of Prow Pass Member. These components were obtained from complete chemical analysis by electron microprobe. 


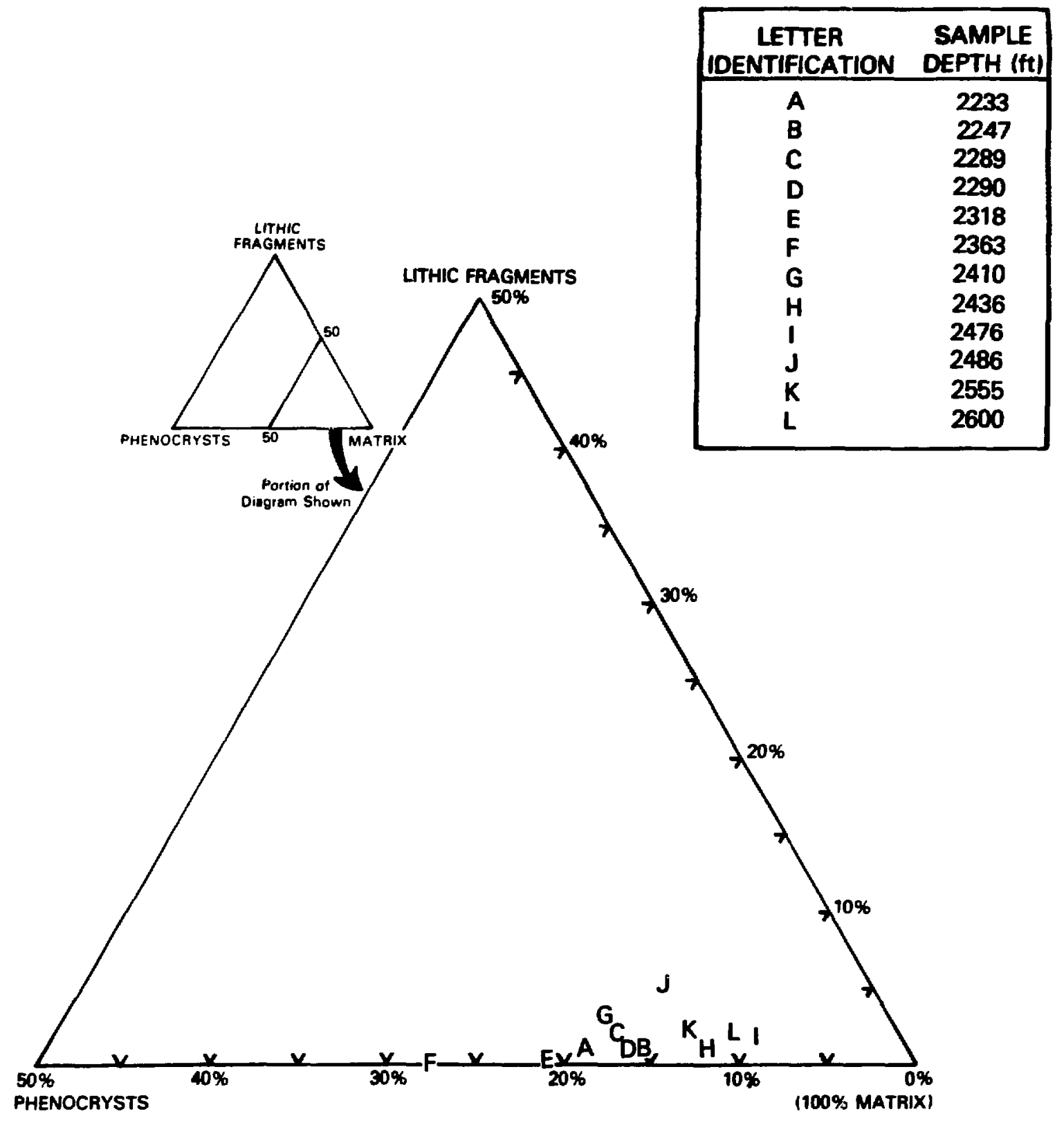

Fig. 15. Proportions of lithic fragments, phenocrysts, and matrix in thin sections of Bullfrog Member. 
Distinctive features of felsic phenocrysts within the Bullfrog include a relatively high degree of "wormy resorption" for quartz (Fig. 16) throughout the unit, and optically distinct overgrowths on rims of many alkali feldspars, particularly above 2317-ft depth. Above 2420-ft depth, areas in thin section for individual alkali-feldspar phenocrysts are as large as $3.3 \mathrm{~mm}^{2}$, plagioclase, $3.0 \mathrm{~mm}^{2}$, and quartz, $2.5 \mathrm{~mm}^{2}$. Below 2420-ft depth, quartz grains do not exceed $1.2 \mathrm{~mm}^{2}$ al though alkali feldspars are as 1arge as $3.8 \mathrm{~mm}^{2}$ and plagioclase $3.0 \mathrm{~mm}^{2}$. The smaller size of the quartz phenocrysts in the lower portion of the unit is not due to the amount of resorption.

Relative proportions of those felsic phenocrysts having the largest areas in thin section (Fig. 17) are randomly variable throughout the stratigraphic section for plagioclase $(35$ to $58 \%)$ and alkali feldspar (26 to $52 \%)$. The proportion of quartz, however, increases systematically from 5 to $13 \%$ for samples collected below $2410-\mathrm{ft}$ depth to $22 \%$ for two samples at 2363- to 2410-ft depth to 31 to $33 \%$ for samples at depths above $2363 \mathrm{ft}$ (with the exception of sample 2289). This increase in quartz corresponds with its increased size at shallower depths.

The compositions of cores, midranges, and rims for both alkali feldspar and plagioclase do not vary significantiy with depth in the Bullfrog Member and all analyses were used for Fig. 18. The median orthoclase $(0 r)+$ celsian $(\mathrm{Cn})$ end member content is $61 \mathrm{~mol} \%$ and the median BaO content is 0.6 wt\% for alkali feldspar (Fig. 18). Most of the $\mathrm{Or}+\mathrm{Cn}$ values are within a narrow range and all such values $<58$ are for rims. The dominant anorthite (An) end member content of plagioclase is $15 \mathrm{mo} 1 \%$ and most of the An values lie within a narrow range from this value (Fig. 18). All An values $>24 \mathrm{~mol} \%$ are for cores.

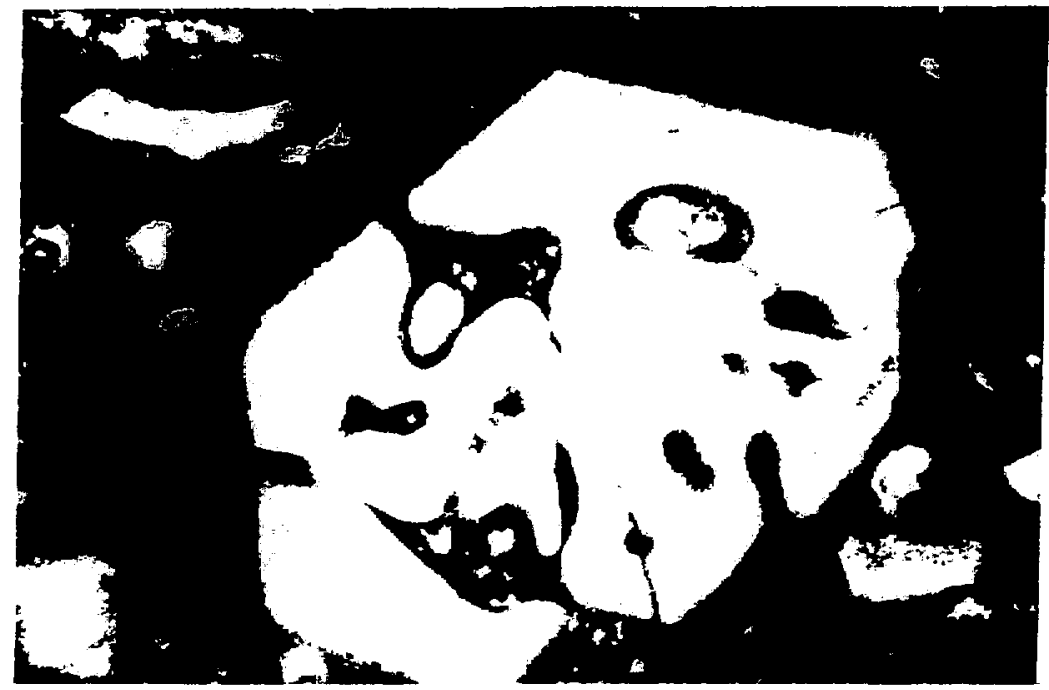

Fig. 16. Transmitted plane light photomicrograph of "wormy resorption" of quartz phenocryst in Bullfrog Member at 2223-ft depth. 


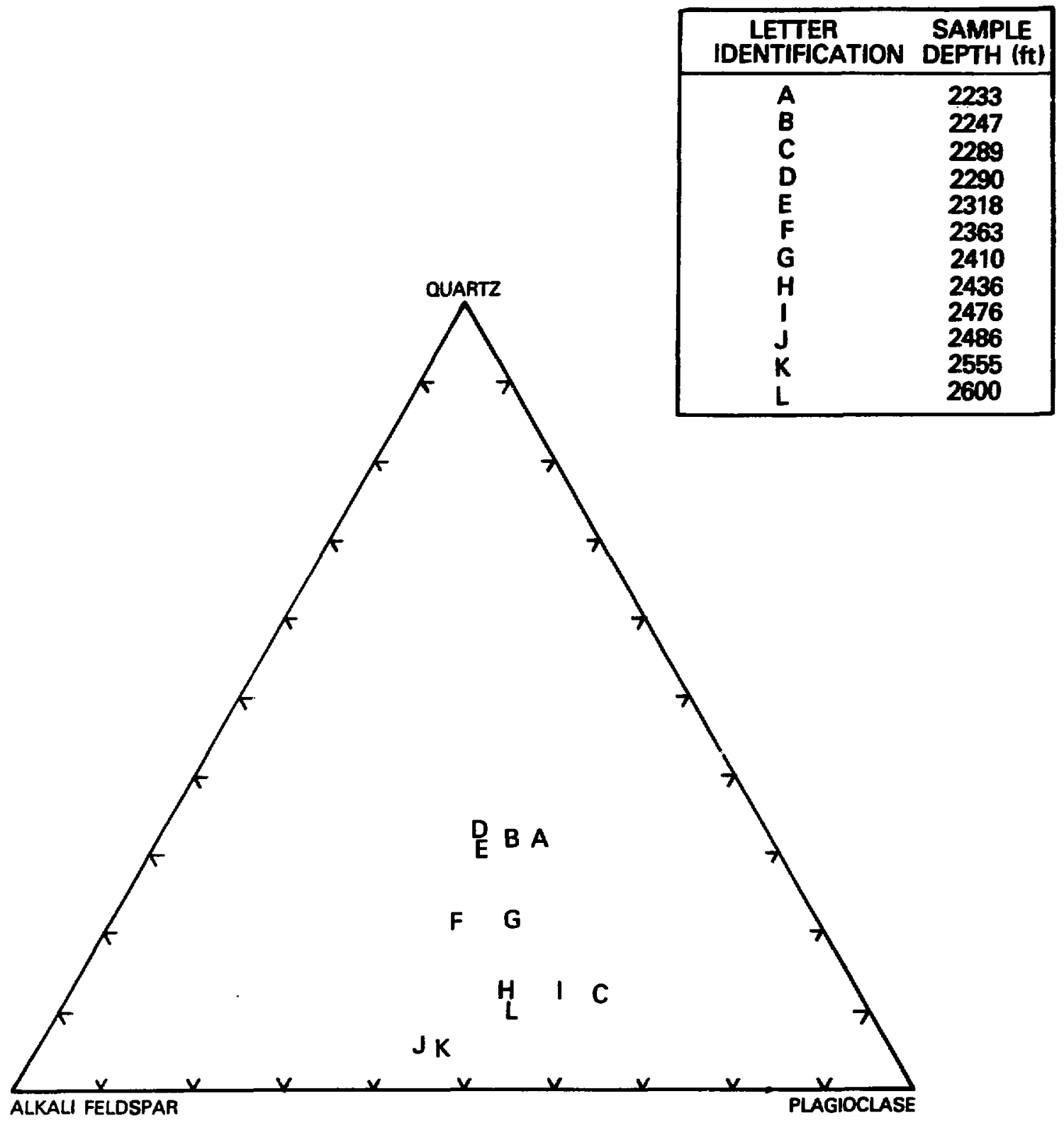

Fig. 17. Relative proportions of those felsic phenocrysts having the largest areas in thin section for Bullfrog Member. 
ALKALI FELDSPAR

Boo, wt \%

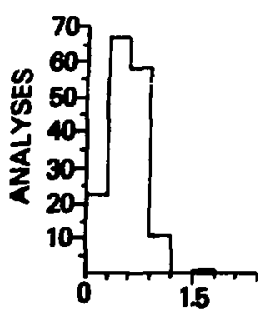

Or $+C_{n}$, MOLY

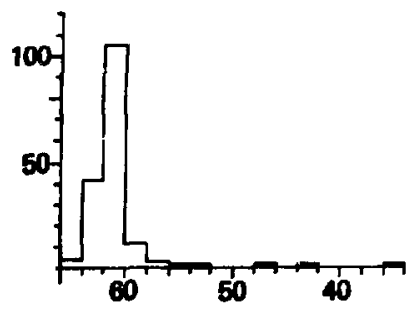

PLAGIOCLASE

An, MOL\%

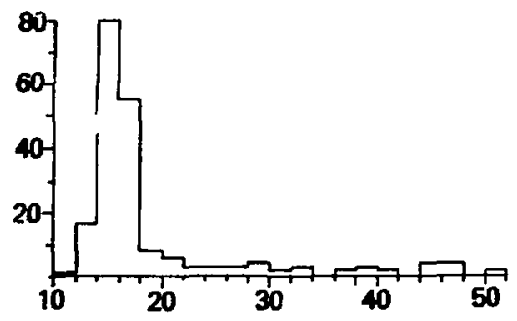

Fig. 18. Histograms of wt\% $\mathrm{BaO}$ and mol \% orthoclase + celsian in alkali feldspar, and mol\% anorthite in plagioclase of Bullfrcg Member. These components were obtained from complete chemical analysis by electron microprobe.

Mafic phenocrysts çonsist solely of biotite (maximum single-crystal area in thin section $0.56 \mathrm{~mm}^{2}$ ) except at 2555-ft depth, where hornblende is also abundant. Hornblende phenocrysts range in size to $0.32 \mathrm{~mm}^{2}$. Many are euhedral twins. The pleochroic formula is $a=$ pale yellow green, $B=$ greenish brown, and $y=$ greenish brown. Most hornblende and biotite phenocrysts are unal tered except for slight blackening of their rims. The most severe alteration of biotite is at 2436-ft depth, where only cores of biotite grains remain unal tered. Below 2317-ft depth, biotite and the hornblende at $2555 \mathrm{ft}$ contain abundant tiny inclusions of euhedral zircon $\left(<0.005 \mathrm{~mm}^{2}\right)$ and apatite $(<0.003$ $\mathrm{mm}^{2}$ ), plus a few larger oxide inclusions. The hornblende also contains biotite inclusions and is itself included within some plagioclase phenocrysts. Above $2317-\mathrm{ft}$ depth such inclusions are rare.

Major-element compositions of biotite do not vary significantly with depth in the Bullfrog Member and all analyses were used for Fig. 19. Biotites are relatively magnesium-poor (median $\mathrm{Mg} /(\mathrm{Mg}+\mathrm{Fe}$ ) molecular ratio $=0.39$ ) throughout the unit, but they contain higher barium contents in the upper portion of the unit than in the lower portion (median $\mathrm{BaO}=1.3 \mathrm{vs} 0.3 \mathrm{wt} \%$, respectively). The hornblende of sample 2555 exhibits $\mathrm{Mg} /(\mathrm{Mg}+\mathrm{Fe})$ ratios of about 0.44 (Fig. 19).

Allanite, found only at 2600-ft depth, occurs as whole or broken twinned prisms with a maximum size of $0.10 \mathrm{~mm}^{2}$. Its pleochroism is a = pale orange, $B=$ orange, and $\gamma=$ dark orange. Many allanite grains are associated with oxides and may contain apatite and zircon inclusions. Sphene is absent from the Bull frog Member.

3. Tram Tuff. The proportions of matrix, lithic fragments, and phenocrysts are shown for each thin section of the Tran tuff in Fig. 20 . Informal lower, middle, and upper subunits (suggested only for discussion) are based on the amount of lithic fragments in each and on other characteristics discussed below. The upper unit (2639- to 3083-ft depth) contains <10\% 1ithic fragments, the middle unit (3083- to $-3350-f t$ depth) contains 20 to $27 \%$ lithic fragments, and the lower unit ( -3350 - to 3522-ft depth) contains 34 to $37 \%$ lithic fragments. The latter two units were combined as the lower Tram in the preceding section. 

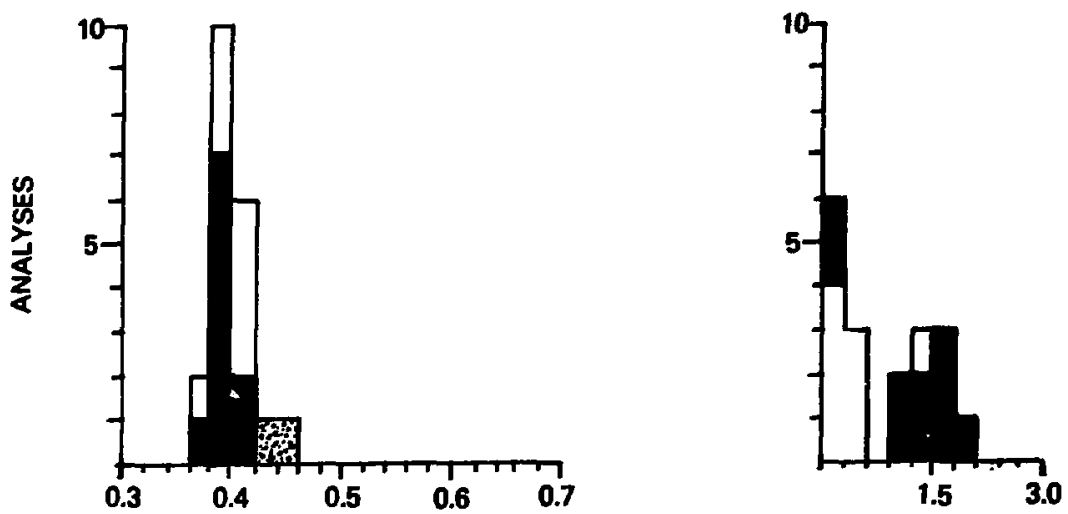

Fig. 19. Histograms of molecular $\mathrm{Mg} /(\mathrm{Mg}+\mathrm{Fe})$ in biotite and hornblende (stippled pattern), and wt $\%$ BaO in biotite of Bullfrog Member. These components were obtained from complete chemical analysis by electron microprobe. Solid pattern for sample depths $2247-2363 \mathrm{ft}$; no pattern for sample depths $2486-2600 \mathrm{ft}$.

Quartz phenocrysts have distinctively larger areas in thin sections of the Tram tuff than in any other unit of the USW-GI core; many have areas $>2 \mathrm{~mm}^{2}$ and the maximum area is $6.0 \mathrm{~mm}^{2}$. Their areas in thin section increase stratigraphically upward except very close to the top of the Tram at 2641-ft depth, where quartz phenocrysts are much smaller. Areas in thin section are slightly larger for alkali feldspar in the upper unit than in the middle and lower units; maximum areas are $2.1,1.3$, and $1.0 \mathrm{~mm}^{2}$, respective1y. Few plagioclase phenocrysts, have areas in thin section $>1.0 \mathrm{~mm}^{2}$, although a maximum area of $2.3 \mathrm{~mm}^{2}$ was observed. Areas in thin section for plagioclase do not vary appreciably throughout the Tram tuff.

The relative proportion of quartz among those felsic phenocrysts having the largest areas in thin section is distinctively high $(>40 \%)$ for al1 thin sections of Tram tuff except at 2641-ft depth (Fig. 21); such high proportions are related to the exceptionally large size of the quartz phenocrysts. Relative proportions of quartz are particularly high (60 to $69 \%$ ) for the middle unit ( 3083 to $\sim 3350-\mathrm{ft}$ depth) and lowest $(40$ to $43 \%$ ) for the lower unit ( $\sim 3350$ - to 3522-ft depth).

The compositions for cores, midranges, and rims of alkali feldspar are similar throughout the Tram tuff, but compositions of plagioclase in the upper and middle units differ significantly from those in the lower unit (Fig. 22). The median orthoclase (Or) + celsian $\left(\mathrm{Cn}_{n}\right)$ end-member content is $67 \mathrm{~mol} \%$ and the median barium oxide content is 0.5 to 0.6 wt\% for alkali feldspar throughout the Tram (Fig. 22). Most of the $\mathrm{Or}+\mathrm{Cn}_{\mathrm{n}}$ values are within a narrow range and all such values $<62$ are for rims. The dominant anorthite (An) end-member content of plagioclase is $21 \mathrm{~mol} \%$ for the upper and middle units, and it is 37 $\mathrm{mol} \%$ for the lower unit. The range in An contents of plagioclase is very broad for the upper and middle Tram and may be due to a bimodal population of plagioclase phenocrysts. 


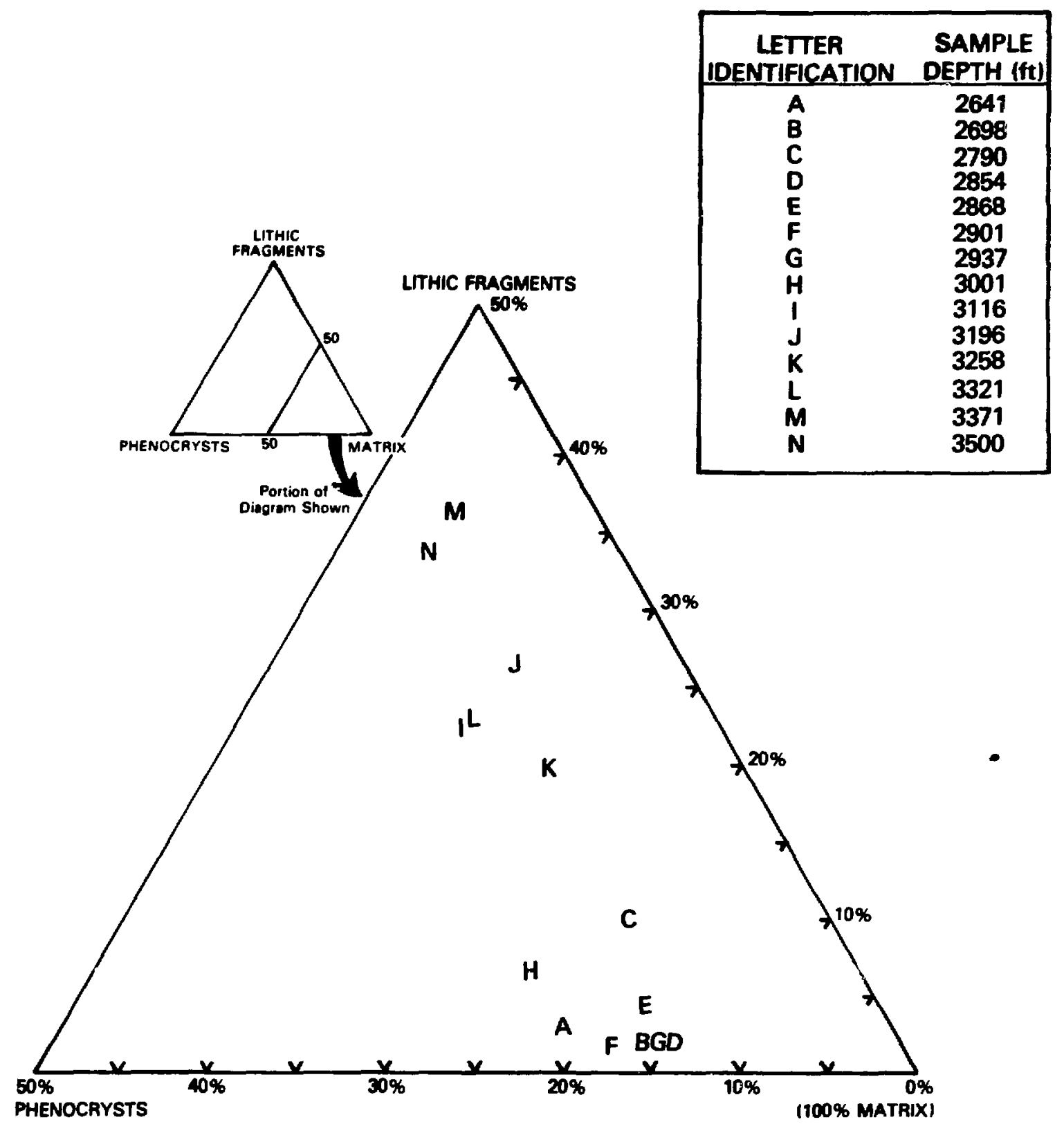

Fig. 20. Proportions of lithic fragments, phenocrysts, and matrix in thin sections of Tran tuff. 


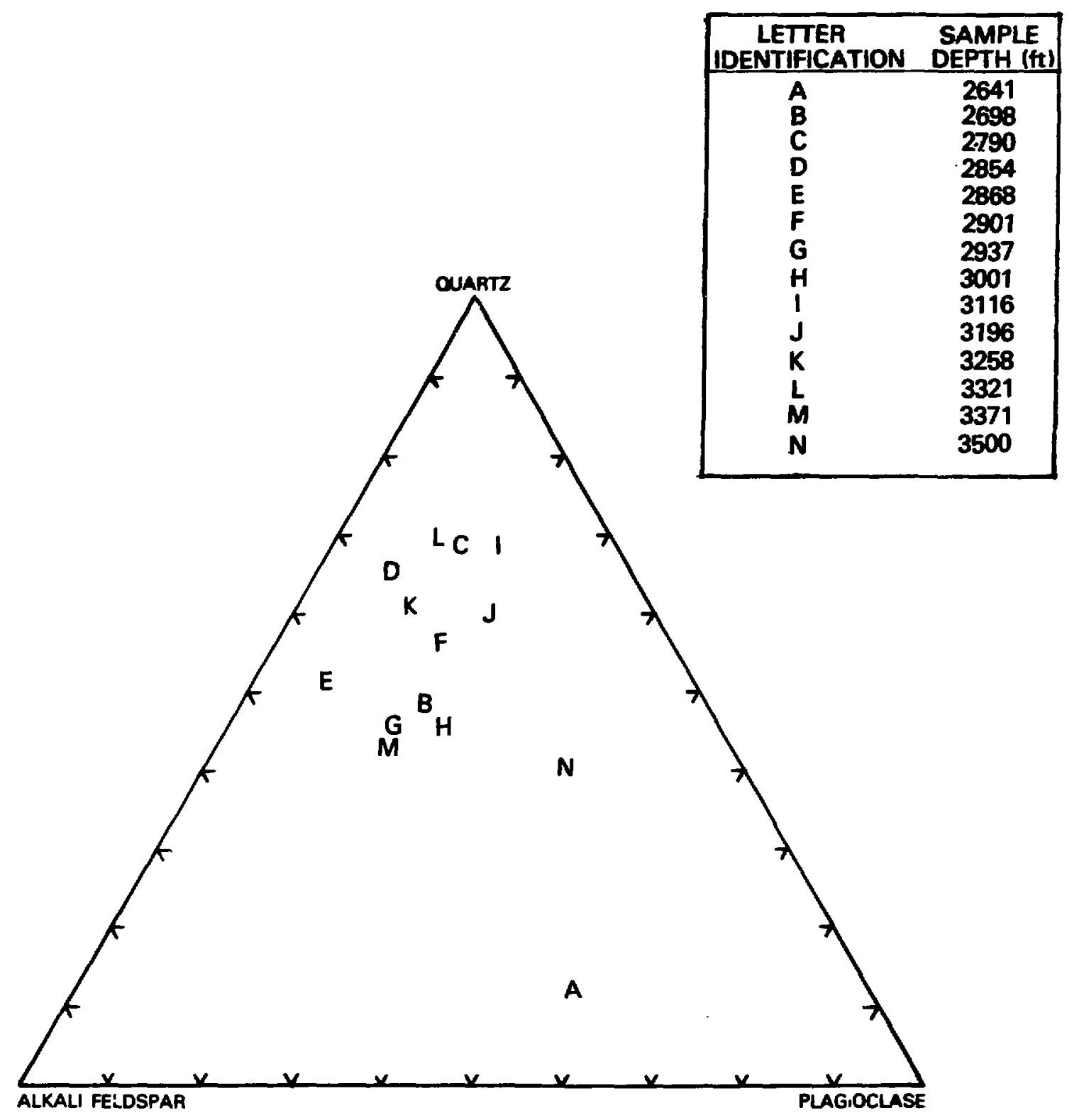

Fig. 21. Relative proportions of those fel sic phenocrysts having the largest areas in thin section for Tram tuff. 
ALKALI FELDSPAR

$B \approx 0, w \%$

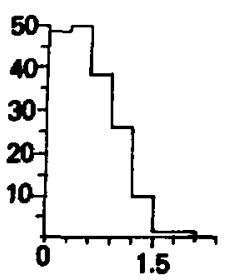

$\mathrm{Or}+\mathrm{Cn}, \mathrm{MOL} \%$

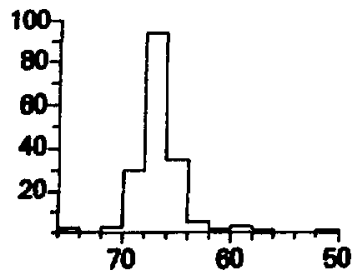

PLAGIOCLASE

An, MOL\%

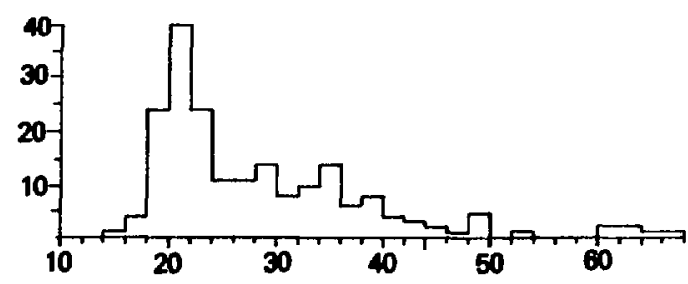

a. Sample depths 2641-3321 ft.
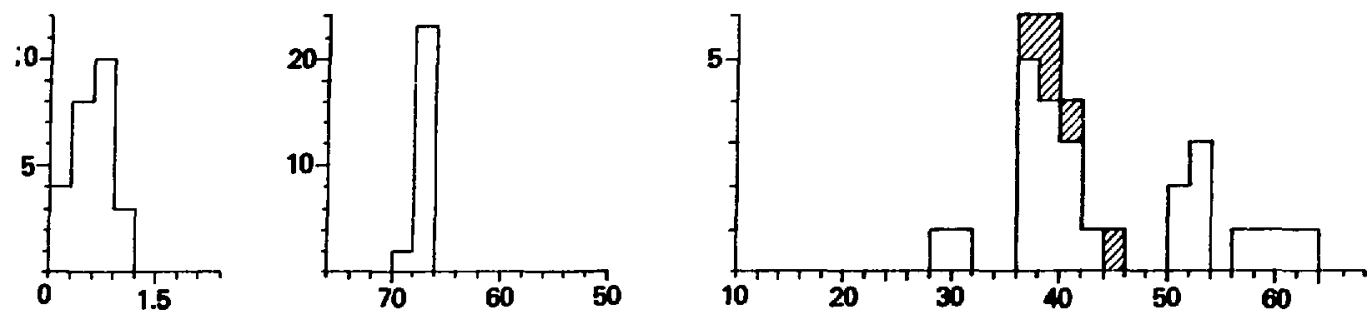

b. Sample depths $3371-3500 \mathrm{ft}$. Diagonal pattern for plagioclase in lithic fragments.

Fig. 22. Histograms of $\mathrm{wt} \% \mathrm{BaO}$ and $\mathrm{mol}_{\%}^{\%}$ orthoclase + celsian in alkali feldspar and mol\% anorthite in plagioclase of Tran tuff. These components were obtained from complete chemical analysis by electron microprobe.

Biotite, having a maximum individual phenocryst area in thin section of $0.52 \mathrm{~mm}^{2}$, is present within the Tram tuff, but hornblende is present only in lithic fragments. Biotite comprises 0.2 to $0.5 \%$ of the rock in the upper unit, $0.1-0.2 \%$ in the middle unit, and 0.05 to $0.1 \%$ in the lower unit. The hornblende in the middle unit occurs at 3258-ft depth in lithic fragments derived from the underlying Dacite flow breccia. Most biotites in the matrix are unal tered except for a slight blackening of their rims, but a few biotites in the matrix are severely altered in a manner similar to those in lithic fragments, and these probably are xenocrysts (Fig. 23). Oxide inclusions are much more abundant in biotite and richer in tiny apatite and zircon within the upper unit than the middle or lower units.

Biotites in the upper unit of the Tran are appreciably more magnesiumrich in the uppermost portion (2641- and 2698-ft depths, Figs. 24a,b) than in the remainder of the upper unit $(2790-$ to $3001-\mathrm{ft}$ depths, Fig. $24 \mathrm{C})$. The composition of biotite is similar throughout the lower and middle units of the Tram and all these analyses were used for Fig. 24d. Most biotites in the matrix of the lower and middle Tran are relatively magnesium-poor (median molecular $\mathrm{Mg} /\left(\mathrm{Mg}+\mathrm{Fe}^{\prime}=0.44\right)$, but a few have higher magnesium compositions $(\mathrm{Mg} /(\mathrm{Mg}+\mathrm{Fe})>0.60)$ that are similar to compositions of biotite in lithic 


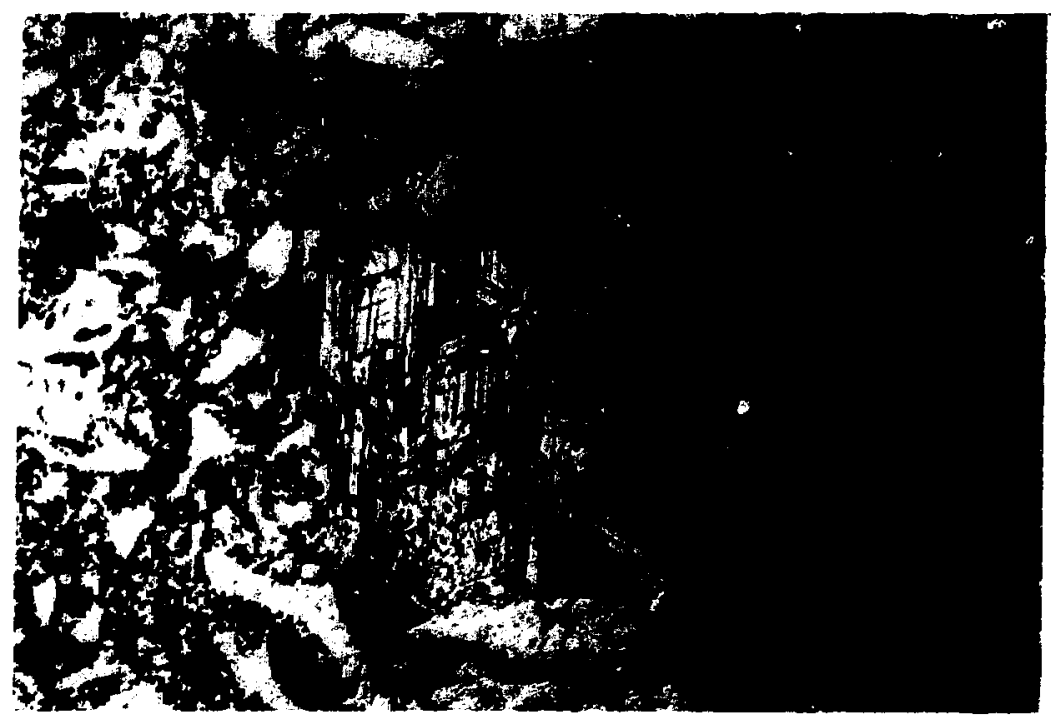

Fig. 23. Reflected plane light photomicrograph of altered biotite in matrix of Tram tuff at 3258-ft depth.

fragments. The median barium oxide content of biotite is 1.0 to $1.6 \mathrm{wt} \%$ throughout the Tram tuff.

Allanite, with a maximum single-crystal area in thin section of $0.05 \mathrm{~mm}^{2}$, occurs throughout the middle and lower units of the Tram, but is absent from the upper unit. Its pleochroism is $\alpha=$ pale greenish yeliow, $B=$ orange, and $\gamma=$ dark reddish orange. Sphene is absent from the Tram tuff.

D.

Summary

Quantitative characteristics such as those described for the Prow Pass and Bullfrog Members of the Crater Flat Tuff and the Tram tuff are sumarized for al1 units of the USW-G1 core between 1191- to 6000-ft depth in Table III. These characteristics are distinct for each stratigraphic unit and will aid greatly in their correlation throughout Yucca Mountain. Sets of certain stratigraphic units have similar phenocryst compositions (Table III) that suggest common or very similar origins for these units.

All units stratigraphically above the Dacite flow breccia contain biotite with median molecular $\mathrm{Mg} /(\mathrm{Mg}+\mathrm{Fe})$ ratios $<0.46$, whereas the Dacite flow breccia and all lower units have biotite with such ratios $>0.55$ (Table III). Eruption of the Dacite flow breccia, which contains retatively abundant, magnesium-rich mafic phenocrysts, is believed to have depleted the amount of magnesium available for biotite in stratigraphically higher units.

The Tram tuff, Lithic-rich tuff, and the upper portion of the 01 der bedded and ash-flow tuffs contain plagioclase having very similar dominant An contents and broad ranges in An contents (Table III). The broad ranges in An contents are due to an abundance of calcium-rich plagioclase phenocrysts having An contents ranging from 28 to 36 in these units. Felsic phenocrysts 
MOLECULAR $\mathrm{Mg} /\left(\mathrm{Mg}+\mathrm{FO}_{\mathrm{O}}\right)$

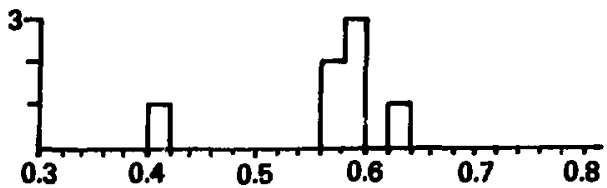

a. Upper Tram, sample depth $2641 \mathrm{ft}$.

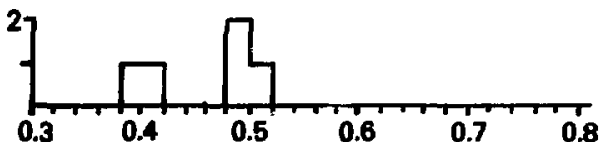

b. Upper Tram, sample depth $2698 \mathrm{ft}$.

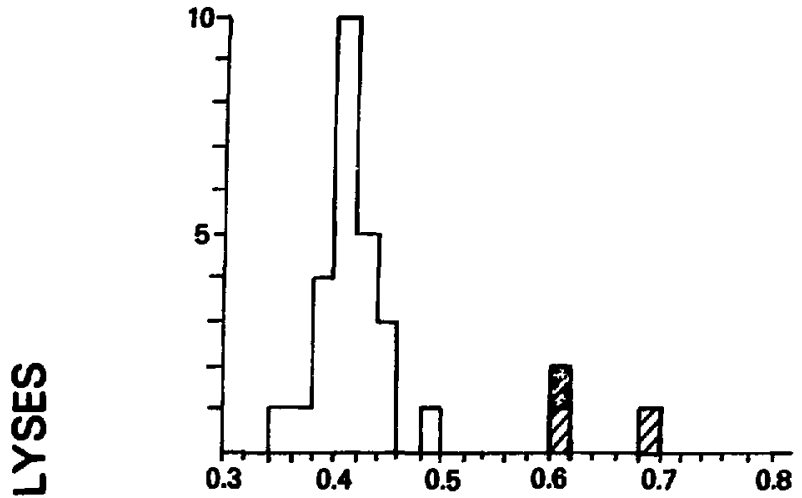

c. Upper Tram, sample depths 2790-3001 ft.
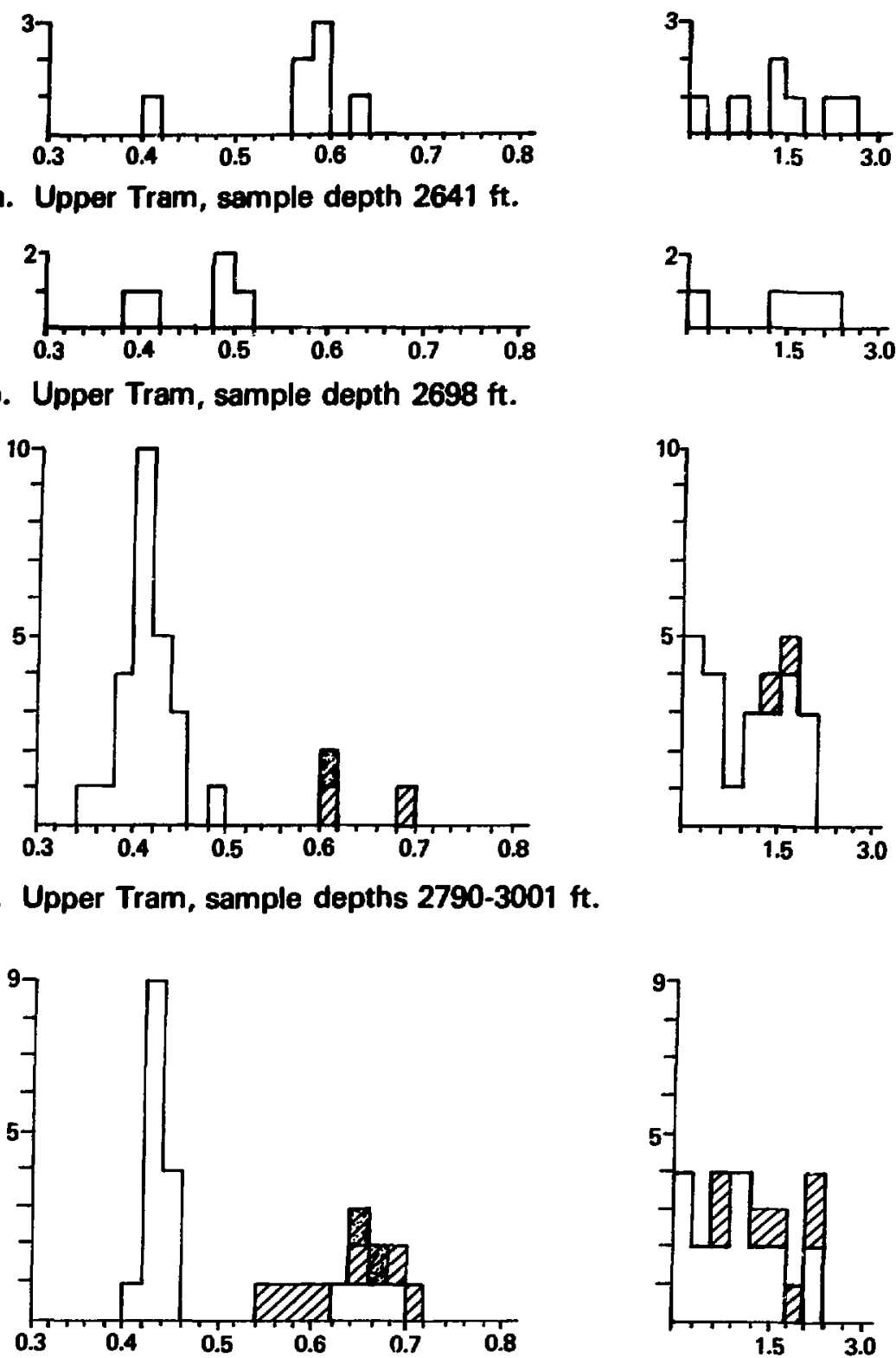

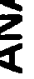

. Lower and middle Tram, sample depths $3116-3500 \mathrm{ft}$.

Fig. 24. Histograms of molecular $\mathrm{Mg} /(\mathrm{Mg}+\mathrm{Fe})$ in biotite and hornblende (stippled pattern), and wt\% BaO in biotite of Tram tuff. These components were obtained from complete chemical analysis by electron microprobe. Diagonal ruling for grains in lithic fragments. 
TABLE III

SUMMARY OF QUANTITATIVE FACTORS THAT CHARACTERIZE STRATIGRAPHIC UNITS

BETWEEN 1191-6000-FT DEPTH IN THE USW-G1 CORE

\begin{tabular}{|c|c|c|c|c|c|c|c|c|c|c|c|c|c|}
\hline \multirow[b]{3}{*}{ Unit } & \multirow[b]{3}{*}{$\begin{array}{l}\text { Iepth } \\
\text { Interval } \\
\text { (ft) }\end{array}$} & \multirow[b]{3}{*}{$\begin{array}{l}\text { Nuber } \\
\text { of Thin } \\
\text { Sections }\end{array}$} & \multirow[b]{3}{*}{$\begin{array}{l}\text { Lithic } \\
\text { Fragnents } \\
\text { (z) }\end{array}$} & \multirow[b]{3}{*}{$\begin{array}{l}\text { Pheno- } \\
\text { crysts } \\
(z)\end{array}$} & \multirow{2}{*}{\multicolumn{3}{|c|}{$\begin{array}{c}\text { 6elative Proportion of } \\
\text { Those Felsic Phenocrys is } \\
\text { Having the Largest } \\
\text { Areas in Thin Section }\end{array}$}} & \multicolumn{4}{|c|}{ Feldspar Compositions } & \multirow{2}{*}{\multicolumn{2}{|c|}{ Blotite Compositions }} \\
\hline & & & & & & & & \multicolumn{2}{|c|}{ Alkal Feldspar } & \multicolumn{2}{|c|}{ Plagtoclase } & & \\
\hline & & & & & Quartz & $\begin{array}{l}\text { Alkali } \\
\text { Feldspar }\end{array}$ & $\begin{array}{l}\text { Plaglo- } \\
\text { clase }\end{array}$ & $\begin{array}{l}\text { Median } \\
\text { Ortcn }\end{array}$ & $\begin{array}{r}\text { Median } \\
\text { We BaO }\end{array}$ & $\underset{\text { An }}{\text { Dominant }}$ & $\begin{array}{l}\text { Range for } \\
\text { most An } \\
\text { Contents }\end{array}$ & $\begin{array}{l}\text { Median } \\
\text { molecular } \\
\mathrm{Mg} /(\mathrm{Mg}+\mathrm{Fe})\end{array}$ & $\begin{array}{c}\text { Medion } \\
\text { Het } \\
\text { BaO }\end{array}$ \\
\hline $\begin{array}{l}\text { Topopah Spring Mbr } \\
\text { (lower part) }\end{array}$ & $1191-1426$ & 5 & $1-5^{b}$ & $1-3^{b}$ & $1-9^{b}$ & $7-17^{b}$ & $34-91^{b}$ & 57 & $<0.1$ & 16 & $14-40$ & 0.44 & $\infty .1$ \\
\hline $\begin{array}{l}\text { Ash-flow tuff of } \\
\text { Calico Hilils }\end{array}$ & $1426-1736$ & 3 & $1-4$ & $3-6$ & $50-58$ & $17-25$ & $22-26$ & 68 & $<0.1$ & 20 & $14-23$ & 0.37 & $<0.1$ \\
\hline $\begin{array}{l}\text { Bedded/reworked tuff } \\
\text { of Calico Hills }\end{array}$ & $1736-1802$ & 1 & 3 & 28 & 32 & 15 & 53 & 73 & $<1.0$ & 37 & $24-40$ & 0.46 & 0.1 \\
\hline $\begin{array}{l}\text { Ash-flow tuff of } \\
\text { Prow Pass Thr }\end{array}$ & $1802-2152$ & 5 & $1-2$ & $9-18$ & $8-15$ & $41-49$ & $41-48$ & 53 & 0.1 & 11 & $8-14$ & 0.42 & 1.6 \\
\hline $\begin{array}{l}\text { Bedded/reworked tuff } \\
\text { of Prow Pass Itor }\end{array}$ & $2152-2173$ & 1 & 2 & 17 & 0 & 36 & 64 & 60 & 0.4 & 17 & $14-20$ & 0.44 & 1.2 \\
\hline Upper Bullfrog Mor & $2173-2420^{\circ}$ & 7 & $0-3$ & $15-27$ & $i 3-33$ & $26-40$ & $35-58$ & 61 & 0.6 & 15 & $13-19$ & 0.39 & 1.3 \\
\hline Lower Bull frog Mor & $242 C^{d}-2639$ & 5 & 1.5 & $8-12$ & $5-13$ & $33-52$ & $42-54$ & 61 & 0.6 & 15 & $13-19$ & 0.20 & 0.3 \\
\hline Upper Tram tuff & 2639-3083 & 8 & $2-10$ & $11-18$ & $44-68^{b}$ & $17-40$ & $Q-25^{b}$ & 67 & 0.5 & 21 & $|7-4|$ & $0.41^{c}$ & $1.1^{c}$ \\
\hline Middle Tram tuff & $3093-3350^{\circ}$ & 4 & $20-27$ & $9-15$ & $60-69$ & $13-26$ & $12-27$ & 67 & 0.5 & 21 & $17-41$ & 0.44 & 1.0 \\
\hline Lower Trum tuff & $3350^{t}-3522$ & 2 & 34-37 & $8-11$ & $40-43$ & 19-37 & $20-41$ & 67 & 0.6 & 37 & $28-63$ & 0.44 & 1.0 \\
\hline Lava of flow breccta & $3568-3920$ & 4 & 0 & $15-26$ & 0 & 0 & 100 & -- & -- & 61 & $54-80^{9}$ & $f$ & -- \\
\hline $\begin{array}{l}\text { Lower tuff of flow } \\
\text { breccta }\end{array}$ & $3920-3946$ & 1 & 7 & 15 & 0 & 0 & 100 & $\cdots$ & -- & 43 & $38-50$ & $0.66^{\circ}$ & 1.9 \\
\hline Lithic-rich tuff & $3946-4940$ & 12 & $10-21^{d}$ & $7-15$ & $0-12$ & $35-71$ & $22-58$ & 65 & 0.7 & 19 & $16-41$ & 0.58 & 1.0 \\
\hline Upper older tuffs & $4940-5320$ & 8 & $2-8^{b}$ & $14-25$ & $22-49$ & $19-55$ & $19-38$ & 64 & 0.5 & 18 & $15-37$ & 0.55 & 0.8 \\
\hline Middle older tuffs & $5320-5434$ & 2 & $11-22$ & $18-23$ & $15-44$ & $8-18$ & $48-67$ & 67 & 0.9 & 29 & $15-36$ & 0.58 & 1.3 \\
\hline Lower older tuffs & $5434-6000$ & 6 & $4-7^{b}$ & $15=32$ & 0 & $0-6$ & $94-100$ & 72 & 3.4 & 32 & $26-45$ & 0.62 & 1.2 \\
\hline
\end{tabular}

Depth given is accurate to $+20 \mathrm{ft}$.

Excludes values for single sample.

Excludes values for two samples.

vedian for hornblende $=0.68$.

Botlte rare: madien for hornblende $=0.66$.

a Dotinant in -47 , range $=46-52$ for microphenocrysts. 
within the lithic fragments abundant in the Tram tuff, Lithic-rich tuff, and upper and middle portions of the 01 der tuffs are mostly calcium-rich plagioclase (An contents $>28$ ). More complete fragmentation of identifiable lithic clasts would result in calcium-rich plagioclase xenocrysts that might differ from plagioclase produced by magmatic processes by their lack of zoning and sma11, angular shapes (features that have been recognized in the Tram tuff). The lower portion of the 01 der bedded and ash-flow tuffs contains abundant calcium-rich plagioclase but few alkali feldspar and quartz phenocrysts (Table III), and lithic fragments of this unit have been found in the Lithicrich tuff. Therefore, it is suspected that the Tram tuff, Lithic-rich tuff, and upper and middle portions of the 01der bedded and ash-flow tuffs incorporated xenocrysts of plagioclase as they were erupted through the lower portion of the 01 der bedded and ash-flow tuffs.

The number of allanite and sphene grains in thin section is summarized for the USW-GI core in Table IV. The abundances of these accessory minerals differ strikingly between portions of some units such as the Lithic-rich tuff that do not differ for any characteristic summarized in Table III. Consequently, abundances of allanite and sphene might allow recognition of specific portions of a stratigraphic unit and aid detailed correlations of units within Yucca Mountain.

\section{ZEOLITIZATION AND ALTERATION PROCESSES}

Zeolite-grade metamorphism has been defined as the lowest grade of regional metamorphic alteration of rocks by Fyfe et al. (1958) based on the early work on burial metamorphism of Coombs (1953). It occurs at temperatures below $200^{\circ} \mathrm{C}$ and pressures below $300 \mathrm{MPa}$ (for example, see Winkler, 1965; Turner and Verhoogen, 1960) and is typical of diagenetic and low-temperature hydrothermal alteration. It is best developed in tuffs or other rocks that initially contained significant amounts of thermodynamically unstable volcanic glass (Hay, 1966; Coombs, 1970; Sheppard, 1971; Hay, 1978; Barrows, 1980). It is also common in argillaceous graywackes and desert alkaline lakes (for example, see Shepard and Gude, 1968, 1969) and is widespread in both shallow and deep marine sediments (for example, see Boles, 1977).

Oniy recently the zeolite grade has been subdivided into zones that are consistent, mappable, and can be correlated between rocks of differing bulk composition (lijima, 1975). Iijima and coworkers tentatively assigned zone boundaries from downhole temperature measurements in Japan to marine tuffs that are currently undergoing zeolitization (Iijima, 1975, 1978, 1980; I ijima and Owha, 1980; I ijima and Utada, 1971). Some applications of recent studies on zeolite zonation to radioactive waste isolation are being reviewed by Smyth and Caporuscio (1981).

The process of zeolitization involves significant exchange of water and cations between pore fluids and solid phases. The zeolite may appear as finegrained replacement of glass, as shard overgrowths, and as veins or irregular masses that fill cavities and fractures. Nonwelded and partially welded glass shards and pumice clasts with large effective surface areas are most affected by zeolitization, whereas densely welded units are least affected. As temperature increases, analcime, laumontite and other zeolites, or albite plus potasssiun feldspar and quartz may replace precursor zeolites such as clinoptilolite, mordenite, and heulandite. Rocks in the deeper zeolite zones may have recrystallized three or more times, effectively obliterating primary 
TABLE IV

SUMMARY OF THE NUMBER OF ALLANITE AND SPHENE GRAINS IN THIN SECTION FOR STRATIGRAPHIC UNITS BETWEEN 1191-6000 FT DEPTH IN THE USW-G1 DRILL CCRE

Unit

Topopah Spring Member (lower part)

Tuff of Calico Hills

Prow Pass Member

Upper Bull frog Member

Lower Bull frog Member

Upper Tram tuff

Lower and middle Tram Tuff

Flow breccia

Lithic-rich tuff

Upper 01 der tuffs

Middle 01 der tuffs

Lower 01 der tuffs

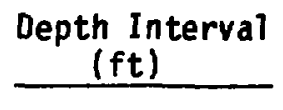

$$
\begin{aligned}
& 1191-1426 \\
& 1426-1736 \\
& 1802-2173 \\
& 2173-2420^{a} \\
& 2420^{a}-2639 \\
& 2639-3083
\end{aligned}
$$$$
\text { 3083-3522 }
$$$$
\text { 3558-3946 }
$$$$
3997-4450^{a}
$$$$
4450^{\mathrm{a}}-4940
$$$$
\text { 4940-5110 }{ }^{\mathrm{a}}
$$$$
5100^{\mathrm{a}}-5320
$$$$
5320-5492
$$

$5492-5800^{a}$

$5800^{a}-6000$
Number of

Thin Sections
Total Number of grains
Allanite Sphene

$\begin{array}{rrr}5 & 1 & 0 \\ 4 & 1 & 0 \\ 6 & 2 & 0 \\ 7 & 0 & 0 \\ 5 & 5 & 0 \\ 8 & 0 & 0 \\ 6 & 20 & 0 \\ 5 & 0 & 0 \\ 6 & 11 & 20 \\ 6 & 5 & 0 \\ 3 & 4 & 0 \\ 5 & 34 & 15 \\ 2 & 2 & 2 \\ 4 & 22 & 19 \\ 2 & 1 & 2\end{array}$

Depth given is accurate to $\pm 50 \mathrm{ft}$.

shard textures and the outlines of earlier zeolites. Phenocrysts in nonwelded and welded units that crystallized at high temperature to anhydrous phases are generally unaffected by early diagenetic zeolitization, except for some fracture fill. As is typical of higher grade regional metamorphism, retrograde metamorphic zeolite minerals are rare. In general, only the minerals of the highest zone attained are preserved, although, in places, minerals typical of lower grades may persist as relict phases or may fill fractures developed subsequent to the highest grade attained.

The specific minerals that develop during zeolite-grade metamorphism are a function of temperature, fluid-phase composition, and initial composition of the rock. Pressure does not appear to be a significant variable in the pressure range below $100 \mathrm{MPa}$ (1 kbar) typical of most zeolite-grade metamorphic 
regimes (Iijima, 1980). Iijima (1975, 1978, 1980) defined two compositionally distinct zeolite sequences: an alkali series dominated by sodium and potassium zeolites typical of altered silicic volcanics, and a calcic series dominated by calcium zeolites typical of altered andesitic to basaltic tuffs. Each series is divided into zones, and temperatures are assigned to zonal boundaries based on extensive temperature measurements in boreholes drilled in the search for petroleum in Japan. These marine tuffs are currently undergoing diagenetic alteration beneath the water table. The mineralogies typical of each series are given in Fig. 25. The temperatures of boundaries between Zones II and III, and III and IV, have been given as a function of sodiun ion concentration in the fluid phase by Iijima (1975). His diagram is reproduced as Fig. 26.

\section{CLAY MINERALS}

The smectite group of clay minerals, including montmorillonite, saponite, and beidellite, is closely associated with zeolites in diagenetically altered tuffs. These common clays occur as $100 \%$ expandable minerals in 10w-temperature environments; with increasing temperature, smectites can be interstratified with a nonswelling clay mineral, usually illite. The transition from a predominantly swelling clay mineral, to an interstratified illite/ smectite, and then to a nonexpanding illite-rich material is well documented in argillaceous sediments subject to low-temperature metamorphism (Perry and Hower, 1970, 1972). This transition, however, has not been fully examined for tuffaceous rocks. Interstratification has important consequences on the physical and chemical properties of clay minerals. Cation exchange capacities

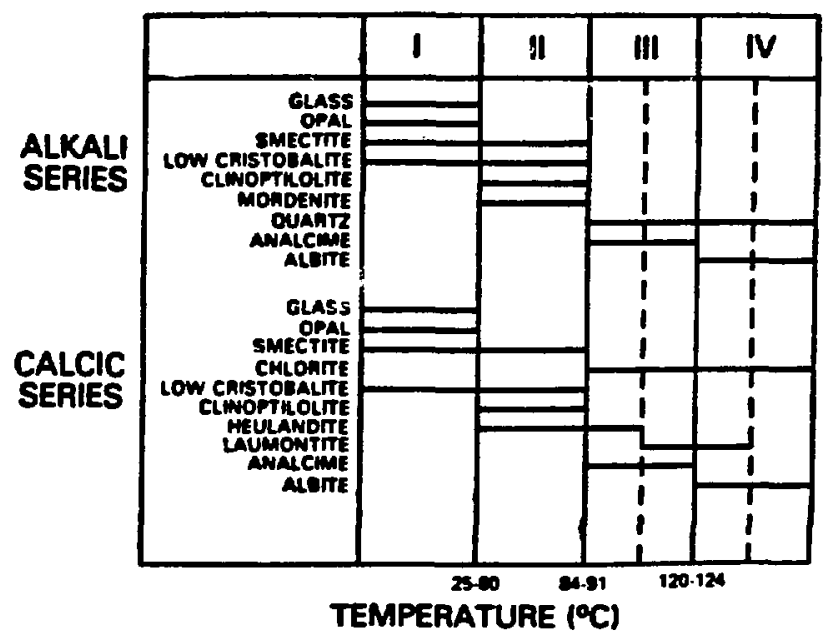

Fig. 25. Zeolite zone mineralogy for alkali and calcic zeolite series. Approximate temperatures of boundaries between zones at bottom of figure are from Iijima (1980) for marine tuffs with high concentrations of sodium ion in pore fluids (Iijima and Ohwa, 1980). 


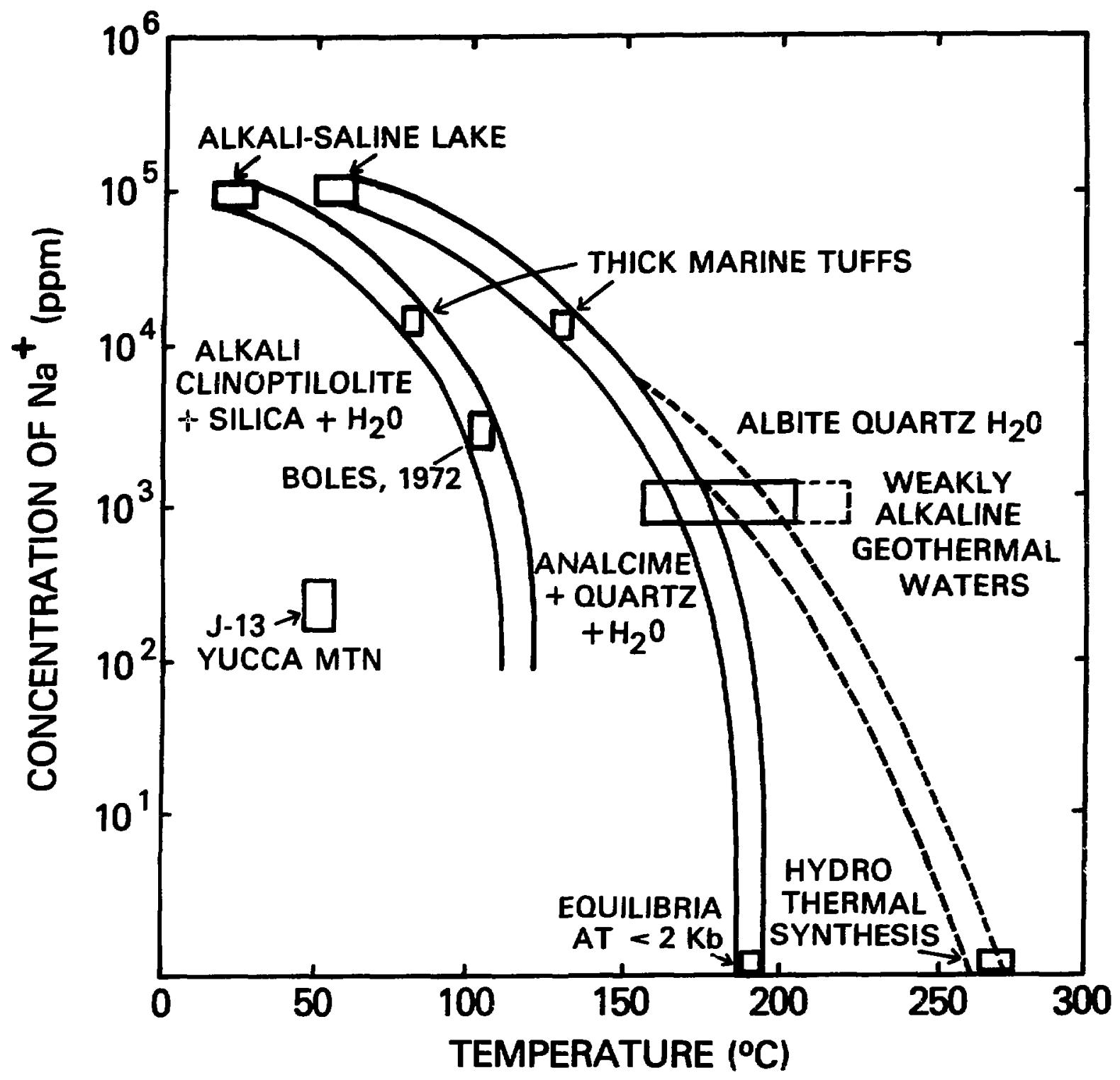

Fig. 26. Sodium ion concentration vs temperature for reactions clinoptilolite + silica + $\mathrm{H}_{2} \mathrm{O}$ - analcime + quartz $+\mathrm{H}_{2} \mathrm{O} \rightarrow$ albite + quartz $+\mathrm{H}_{2} \mathrm{O}$ (Iijima, 1975). Yucca Mountain data added (Smyth and Caporuscio, 1981). Stability fields of the above phase assemblages are labeled. 
decrease from 80 to $130 \mathrm{meq} / 100 \mathrm{~g}$ for some pure smectites to less than $15 \mathrm{meq} / 100 \mathrm{~g}$ for illite-rich interstratifications. Swelling and dehydration properties are affected in a similar manner; the c dimension of smectites may vary by more than $50 \%$ with small changes in temperature and water pressure, while illites are only slightly affected. Smectites commonly lose between 5 and 15 wt\% water on heating to $100^{\circ} \mathrm{C}$, illite/smectites 1 ose 4 to $10 \%$, and illites lose less than $2 \%$ water.

Dioctahedral sodium-potassium smectites with little or no interstratified illite may be abundant in Zeolite Zone I of Iijima (1975), especially in nonwelded units. Smectites may completely replace welded tuff units. Clays are present in at least minor amounts in all zones of the tuffs from Yucca Mountain (Heiken and Bevier, 1978; Sykes et al., 1979). In general, complete clay alteration of welded, devitrified tuff from the Yucca Mountain area tends to be confined to borders of significant fractures. Chlorites have been identified in Zones III and IV in thin section but have not been unequivocally identified by $x$-ray ciffraction. (Chlorites are easily confused with kaolinite by $x$-ray methods.) In the lower portions of Zone IV, secondary biotite appears to replace some clay-rich bands observed in thin sections.

In nonwelded zones, clays occur finely disseminated throughout the matrix, and in the Topopah Spring Member a few isolated horizons are completely replaced by smectite clays. Finely disseminated clays also may be the product of postcooling alteration of residual glass in welded units. In some cases, major clay alteration in the Topopah Spring appears to be related to fractures and occurs as an alteration rind up to several centimeters on either side of fractures, particularly in and adjacent to the basal vitrophyre. clearly, fracture permeability is an important factor in the formation of clays in tightly welded tuff.

\section{SYNOPSIS OF ALTERATION ZONES IN USW-G1}

Zone I of Iijima comprises the lowest temperature and pressure regime and ranges from no alteration to local complete replacement by smectite clays and opal. The dominant clay mineral is a dioctahedral Na-K smectite with minor opal and chalcedony. In USW-G1, this zone extends from the surface to the lower portion of the Topopah Spring Member of the Paintbrush Tuff (Fig. 27).

The first unit encountered in drilling USW-G1 was the Yucca Mountain Member, below which is the Pah Canyon Member, both of the Paintbrush Tuff. Both members are nomwelded where exposed in upper Drill Hole Wash. These upper members of the Paintbrush Tuff were not cored in USW-G1, but dril1 chips and nearby outcrop samples were examined. Alteration in these units is principally confined to local clay-rich horizons. The nonwelded units show pervasive and locally extensive development of smectite; however, most samples appear essentially unaltered and fresh.

The Topopah Spring Member is a thick, compound cooling unit of ash-flow tuff. It shows a densely-welded, devitrified central zone approximately $1000 \mathrm{ft}$ thick, a lower vitrophyre approximately $50 \mathrm{ft}$ thick, and a basal nonwelded zone. Minor amounts of nearly $100 \%$ expandable smectites are present throughout the welded portion of this member. These clays may comprise up to $10 \%$ of samples in this unit and are disseminated through the finely crystallized matrix. Locally, along fractures, clays may completely replace the matrix of the tuff and comprise $40 \%$ or more of some samples (for example, see $995 \mathrm{ft}, 1286 \mathrm{ft}$ ). 


\section{YUCCA MOUNTAIN LITHOLOGIES}

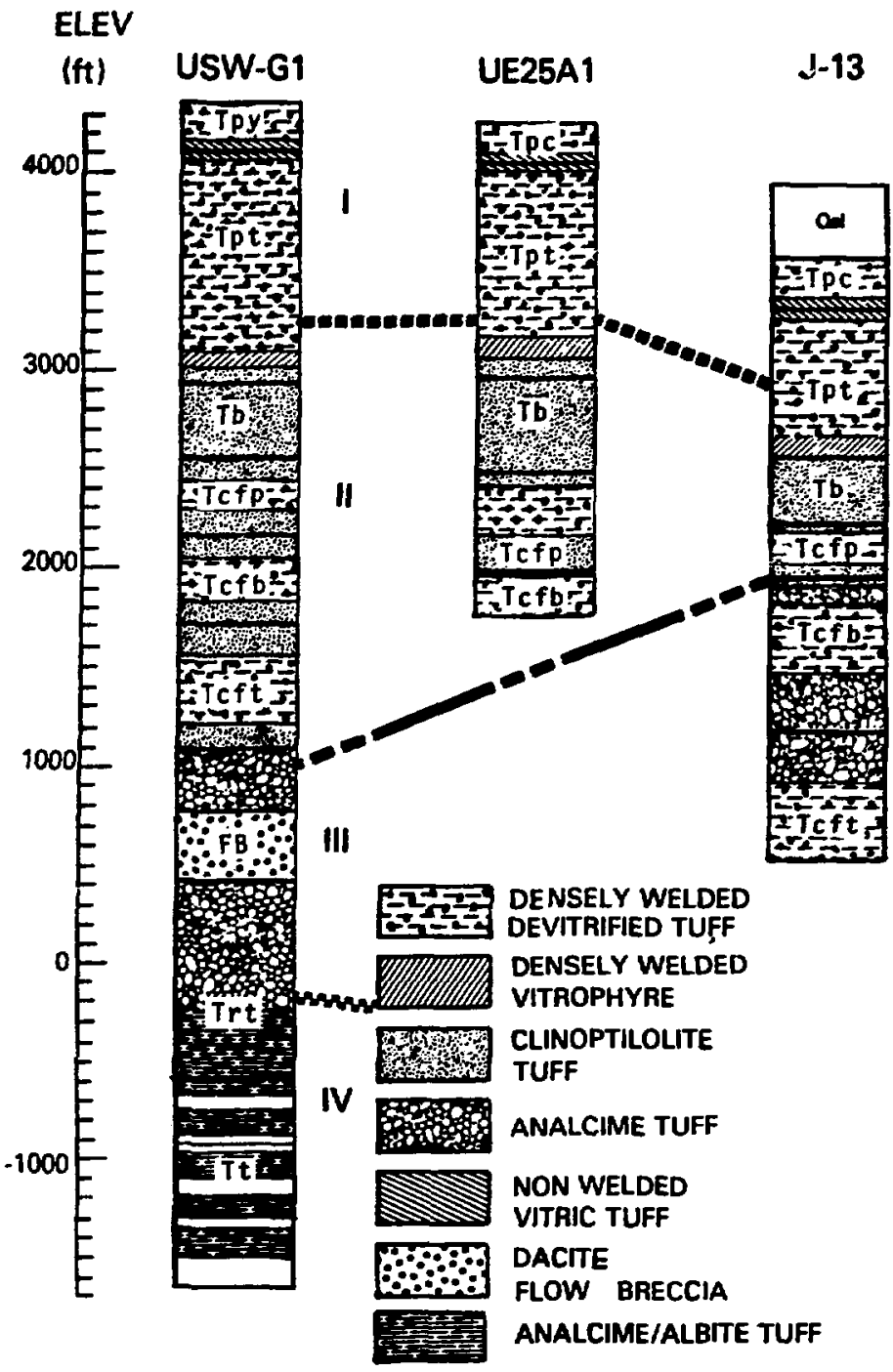

Fig. 27. Lithology diagram for USW-G1, UE25a-1, and J-13 drill holes. Zeolite zones are shown as Roman numerals, and boundaries are correlated between holes. (For explanation of stratigraphic symbols see Fig. 2.) 
The top of Zone II (Fig. 27), at about $1280 \mathrm{ft}$, is placed at the first occurrence of pervasive replacement of matrix by clinoptilolite. A few minor occurrences of this zeolite fill fractures and line cavities above this level. At the $1280-\mathrm{ft}$ level, clinoptilolite is associated with extensive smectite alteration around fractures just above the basal vitrophyre. The zeolite at this first occurrence is more properly termed heulandite because it is rich in calcium and low in silica, similar to the first occurrence in drill hole UE25a-1 (Sykes et al., 1979). Only minor amounts of smectite were noted in the center of the vitrophyre; however, appreciable (true) clinoptilolite is present at the bottom of the vitrophyre, particulariy in compacted pumices.

Extensive clinoptilolite alteration has affected the Bedded tuff of Calico Hills and extends into the nonwelded top of the Prow Pass Member of the Crater Flat Tuff. The clinoptilolite here is a true alkali clinoptilolite as defined by Boles (1972) with high Si and low Ca. It may comprise $80 \%$ or more of some horizons. The central portion of the Prow Pass Member was densely welded, and it devitrified during cooling to alkali feldspar, quartz, and cristobalite. Zeolites were not observed in samples from the 1883-, 1942-, and 1982-ft levels in this drill hole. Below the welded central portion of this unit, zeolite alteration is again extensive in the nonwelded base and into the nonwelded to partly welded top of the Bullfrog Member. Dioctahedral smectites are sporadically developed in the top of the Bullfrog. Also in this member, we begin to see extensive development of mordenite, which appears as sprays of fibrous crystals (Fig. 28). The relationship between clinoptilolite and mordenite is not understood. They have very similar compositions, and the mordenite may have replaced clinoptilolite as temperature increased. However, this is difficult to document or infer from textural evidence because the only mordenite positively identified in thin section grew into cavities.

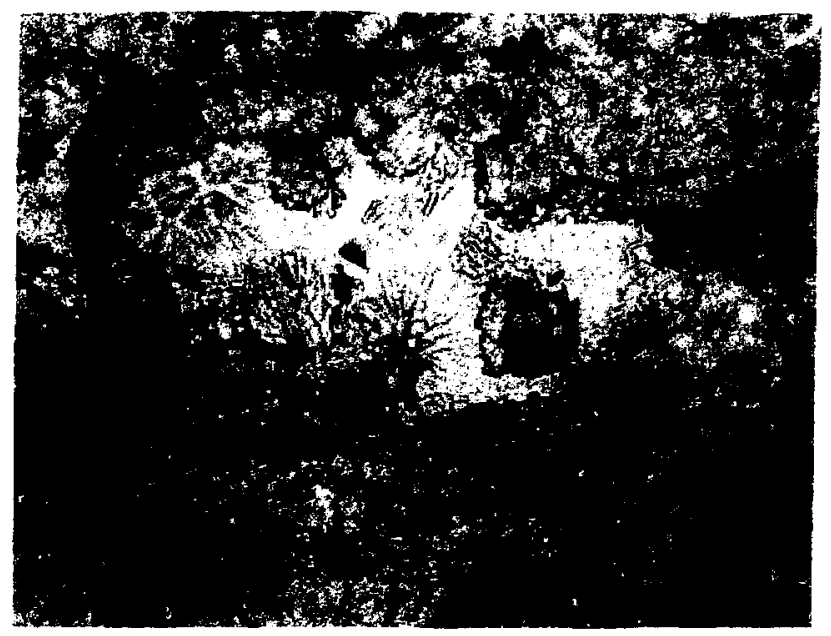

Fig. 28. Sprays of mordenite needles and clinoptilolite prisms project into cavity in nonwelded upper portion of Tram tuff at depth of $2698 \mathrm{ft}$. USW-G1, plane light, $100 \times$ magnification. 
Development of mordenite is sporadic through the upper subunit of the Bullfrog and increases in the upper nonwelded portion of the lower subunit.

The moderately to densely welded core of the lower subunit is devitrified to pretominantly quartz and alkali feldspar with only minor cristobalite. This contrasts with densely welded units above this level (Prow Pass and Topopah Spring) in wich cristobalite predominates over quartz. It may be that the temperatures and pressures of middle-to-lower Zeolite Zone II have inverted the metastable cristobalite to quartz, the stable form of $\mathrm{SiO}_{2}$ in this P-T range. In the welded, devitrified zone, we observed a slight increase in dioctahedral smectite content over zeolitized units above; these are $\mathrm{Na}-\mathrm{K}$ smectites randomly interstratified with less than $10 \%$ illite.

Below the welded central portion of the Bullfrog, we again see extensive zeolitization of the non- to partly welded lower portion of the Member. Smectites are scarce or absent in this region. There is extensive development of mordenite in samples from 2555- and 2600-ft depths; however, the percentage of mordenite appears to decrease with depth and is in $10 \mathrm{w}$ abundance in zeolitized samples from the upper portion of the Tram. The percentage of clinoptilolite then decreases with increased welding, and zeolites are absent from the welded central portion of the Tram, except as minor fracture fill.

The moderately to densely welded, nonzeolitized core of the Tram extends from about $2750 \mathrm{ft}$ to about the 3050-ft depth. As in the welded portion of the Bullfrog, there are pervasive dioctahedral Na-K smectites with less than $10 \%$ illite comprising up to $10 \%$ of samples from the welded portion of this unit. Here again, quartz predominates over cristobalite.

The top of Zone III (Fig. 27) is placed at about the 3100-ft level because of the pervasive development of analcime and quartz replacing precursor clinoptilolite, although traces of analcime occur as high as the $3000 \mathrm{ft}$ level. Na-K dioctahedral smectites similar to those in Zones I and II are common in the top of Zone III. These smectites are interstratified with less than $15 \%$ illite, and preliminary data show no clear trend of increasing interstratification with depth. The lower $490 \mathrm{ft}$ of the Tram Tuff is non- to partly welded ash-flow tuff, and replacement of clinoptilolite by analcime is somewhat sporadic. Such a replacement involves a major exchange of alkali and alkaline-earth cations: the principal alkali cation in analcine is sodium, whereas clinoptilolite and mordenite contain variable proportions of sodium, potassium, and calcium. The replacement of precursor zeolites by analcime is a function of sodium-ion concentration in fluids as well as temperature (Iijima, 1975), so its development is likely to be strongly controlled by permeability, particularly near the edge of its stability zone.

Also in the nonwelded base of the Tram, we observed secondary sulfides with pyrite replacing and surrounding oxide minerals and growing freely in open fractures. The presence of ferrous iron and reduced sulfur indicates fairly low-oxygen fugacities during al teration of these rocks, al though it may be lowered by proximity to the lava flows and breccias immediately below the base of the Tram.

Below the Tram is the Dacite flow breccia. The groundridss, which was initially glassy, is now altered to smectite interstratified with less than $20 \%$ illite. Alteration appears to be controlled by fluid access with smectites forming along fine fractures observed in thin section. Substantial amounts of unaltered perlitic glass were observed in thin section. Coarse crystals of clinoptilolite up to $2 \mathrm{~mm}$ in length partially fill fractures in this unit, but pervasive development of zeolites in the groundwass was not observed. Microprobe chemical analysis of this zeolite indicates that it is 
a sodium-rich, high-silica clinoptilolite, and thus is an exceedingly rare occurrence of coarsely crystalline clinoptilolite.

Below the Dacite flow breccia, the lithology returns to silicic ash flow in the unit termed Lithic-rich tuff. This is a thick non- to partly welded ash-flow sequence that has been extensively altered. The groundmass phases are typically analcime, quartz, and potassiun feldspar. Clay alteration is extensive, especialiy in and near fractures and in pumice clasts.

The first authigentc albite in the core was noted in sample 4341 and again in 4400, where it has partly replaced coarsely crystalline analcime and grows into or fills cavities and vugs (Fig. 29). Authigenic albite was not observed again until below the 5000-ft level. However, positive identification at 4340 and $4400 \mathrm{ft}$, where it clearly replaces analcime, would place the top of Zone IV at about $4350 \mathrm{ft}$ for purposes of estimating the maximum temperatures to which the rocks were exposed. Authigenic albite in these rocks is nearly pure albite with less than 3 mol\% potassium feldspar and no detectable calcium, barium, magnesium, or iron. This is consistent with its growth from a nearly pure sodic analcime.

Below $5000 \mathrm{ft}$, authigenic albite and potassium feldspar become the dominant secondary minerals in the nonwelded as well as in welded units. These interbedded welded and nonwelded ash-flow, airfa11, and reworked tuffs have, in some cases, become so recrystallized that original textures are difficult to recognize in thin section. Chlorite and celadonite are both common in these lower units and appear to replace clays and oxide minerals. Microprobe chemical analysis indicates that some chlorites contain 25 wt $\%$ or more FEO.

A. Maximum Geothermal Gradient

From zeolfte-zone boundaries, it is possible to estimate a maximum paleogeothermal gradient for USW-G1. Following the temperature zones of Iijima (1975, 1978, 1980) and Iijima and Oima (1980), it is possible to estimate temperatures of zone boundaries achieved in the rocks of the core. Sodium concentrations present in pore fluids are estimated to be 200 to $1000 \mathrm{ppm}$ based on we1l water compositions between 200 and $500 \mathrm{ppm}$ (Winograd and Thordarson, 1975). This would place the Zone I-II boundary at 40 to $65^{\circ} \mathrm{C}$, the Zone II-III boundary at 95 to $105^{\circ} \mathrm{C}$, and the Zone III-IV boundary at 130 to $145^{\circ} \mathrm{C}$ (Ijjima, 1975 and $\mathrm{Fig}$. 26). Plotting our observations of these zone boundaries, we obtain an estimated maximum paleogeothermal gradient for USW-G1 (Fig. 30) substantially above what is currentiy measured within the drill hole. The three points plot reasonably close to a straight line intersecting the surface near $20^{\circ} \mathrm{C}$.

This is evidence of low-grade hydrothermal activity in this area in the past, not surprising for a thick pile of volcanic rocks. This hydrothermal activity is sufficiently low in grade that one would not expect to find a shallow pluton within 1 or $2 \mathrm{~km}$ of the bottom of USW-G1. The activity may be related to Crater Flat Caldera or to the much higher grade hydrothermal alteration that is present in Calico Hills to the northeast. The nearly straight line of the maximum paleogeothermal gradient may be taken as evidence that the maximum temperatures were reached after the youngest units (that is, Paintbrush Tuff) were in place. The lack of zeolites in the current zone I is evidence that the upper units have never been deeply buried and that temperatures in this zone never rose above about $50^{\circ} \mathrm{C}$ for any length of time (see Fig. 30). This may be taken as evidence that Yucca Mountain has remained a relatively stable structural block since emplacement of the Paintbrush Tuff. 


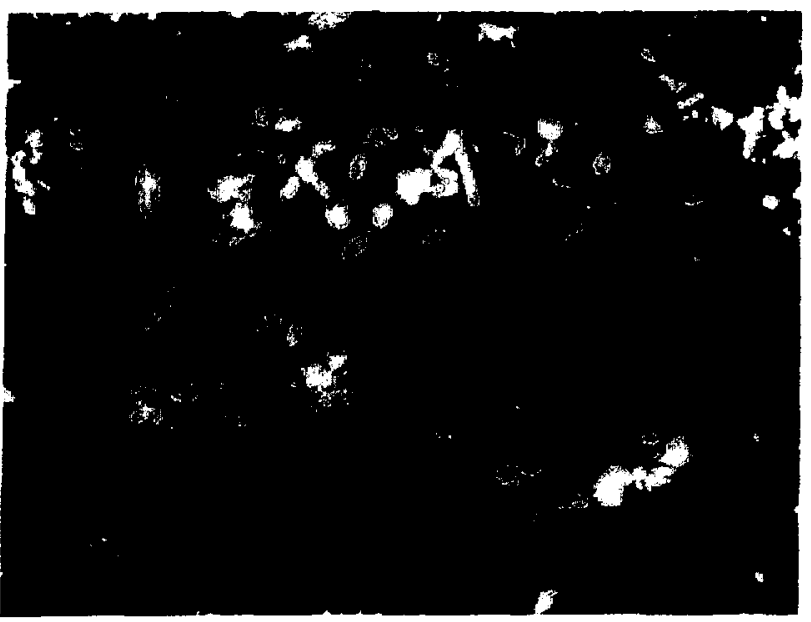

A.

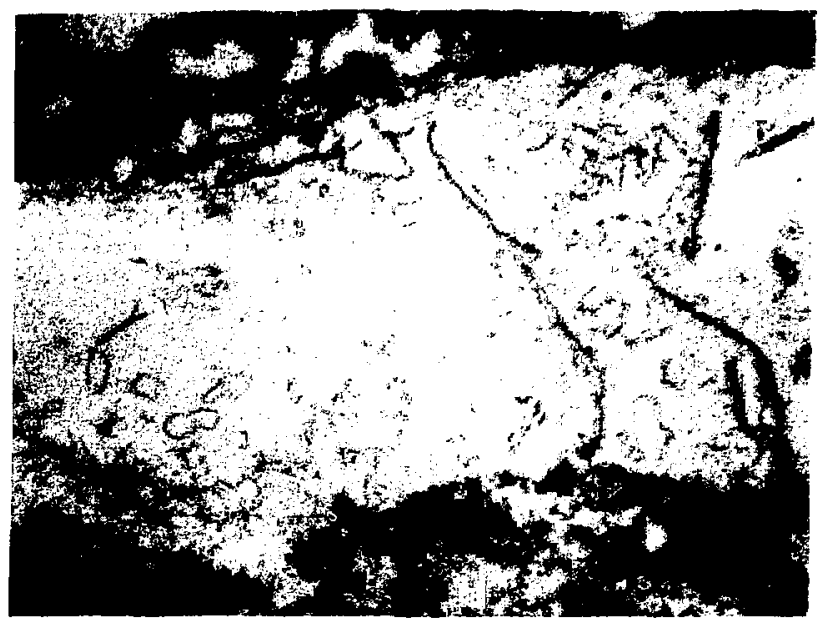

B.

Fig. 29. Photomicrographs of authigenic albite growing in nearly isotropic coarsely crystalline analcime. Slight anisotropy in analcime can be seen at right in $A$. This sample from $4400-\mathrm{ft}$ depth marks the top of zeolite Zone IV. USW-G1, $30 \times$ magnification, A. crossed polars, B. plane-polarized light. 


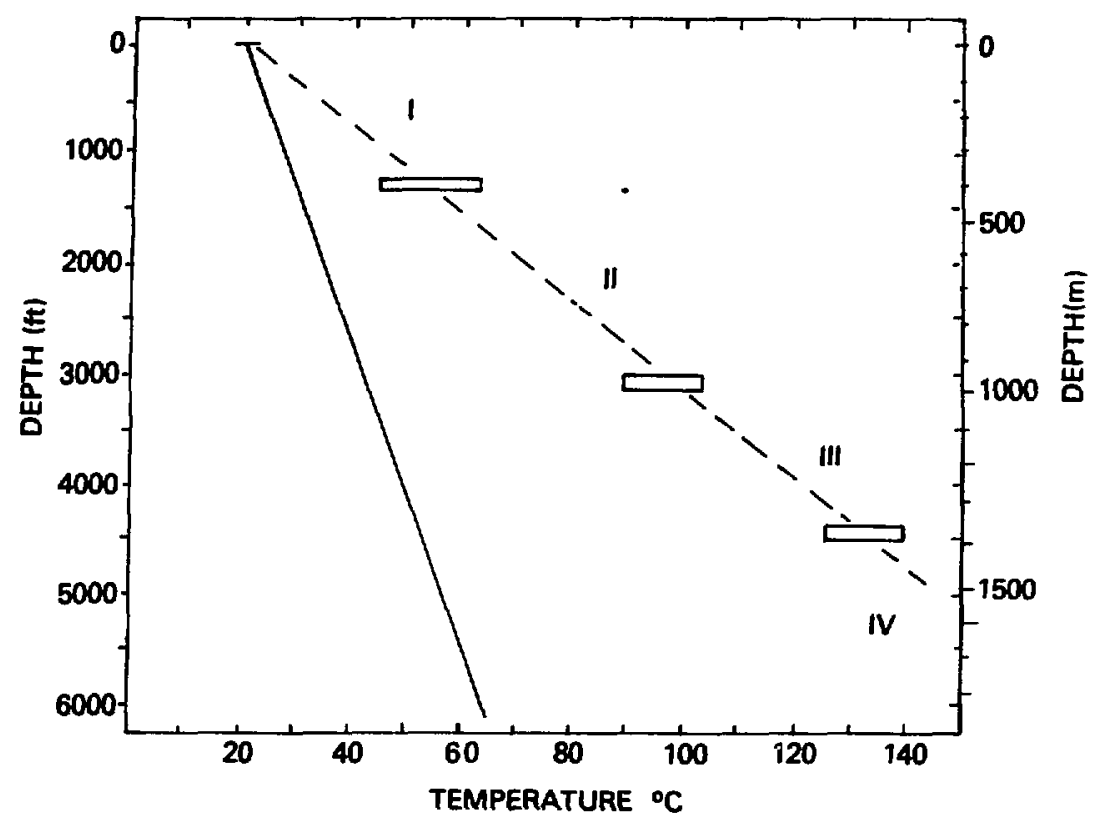

Fig. 30. Approximate current geothermal gradient of drill hole USW-G1 is shown by solid line. Estimate of maximum paleogeothermal gradient is shown by dashed line. Data points are probable temperature ranges of boundaries between zeolite Zones I, II, III, and IV in the cores.

The temperatures estimated from zeolite-zone boundaries, however, do not agree with the temperatures expected from the degree of interstratification in the smectites. Perry and Hower (1970) found that the percent expandability in smectite/illite decreased to $60 \%$ at $60^{\circ} \mathrm{C}, 40 \%$ at $80^{\circ} \mathrm{C}$, and $20 \%$ at $100^{\circ} \mathrm{C}$ in Gulf coast oil wells. The lack of agreement between zeolite and illite/ smectite temperatures suggests that the zeolites and clays may have formed at separate times.

B. Oxide Mineral Alteration Trends

Ubiquitous Fe-Ti oxides are observed both as microphenocrysts and as al teration products in the ash flows and lavas. Morphologies indicate that both cubic [magnetite-ulvospinel solid solution series (Mt-Uspss)] and rhombohedral [ilmenitehematite solid solution series (IIm-He: $\left.{ }_{S 5}\right)$ ] phases are present. Subsequent oxidation of the Fe-Ti oxides after eruption produced a series of oxidation exsolution stages in the original grains. Haggerty (1976) has devised a series of empirical oxidation exsolution stages for both the cubic $\left(C_{1}\right.$ to $\left.C_{7}\right)$ and rhombohedral $\left(R_{1}\right.$ to $\left.R_{7}\right)$ phases, where 1 denotes unoxidized and 7 denotes complete oxidation. That classification is used in this report to identify the relative maximum oxidation state of the samples (Table V). In all cases, the oxidation state of the Ilm-Hemss closely parallels that of the Mt-Uspss. Therefore, all oxides reported are given a C-identification for consistency. The oxidation state of the Fe-Ti oxides is 
EXSOLUTION OXIDATION OF FE-Ti OXIDE CUBIC ANO RHOMBOHEDRAL PHASESa

Cubic

$c_{1}$ magnetite

$C_{2}$ magnetite $(+i$ menite)

$C_{3}$ ilmenite + magnetite

$C_{4}$ mottled ilmenite + magnetite + rutile + hematite + pleonaste (meta-ilmenite)

$C_{5}$ rutile + titanohematite

$C_{6}$ rutile + titanohematite $R_{6}$ (+ pseudobrookite)

$C_{7}$ pseudobrookite + (titanohematite + rutilel
Rhombohedral

$R_{1}$ ilmenite

R2 ilmenite + rutile

$R_{3}$ rutile + ilmenite

$\mathrm{R}_{4}$ rutile + titanohematite + ferrian rutile + ferrian ilmenite

$R_{5}$ rutile + titanohematite

$R_{6}$ rutile + titanohematite

(+ pseudobrookite)

R7 pseudobrookite + (rutile + titanohematite)

a After Haggerty, 1976.

dependent on the ambient fo2, which in curn can be correlated to the permeability and degree of welding of the tuffs. For nonwelded tuffs (high permeability), the $\mathrm{Fe}-\mathrm{Ti}$ oxides typically are highly oxidized $\left(\mathrm{C}_{6}-\mathrm{C}_{7}\right)$. Densely welded tuffs (10w permeability) record low oxidation states $\left(C_{1}-C_{3}\right)$. Exceptions are notable near the base of the Tram and the lower portion of the 01 der bedded and ash-flow tuffs. In both instances, the fluids that permeated the tuffs had low for and, therefore, the oxides are only partly oxidized. The oxidation state for tuff units having comparable degrees of welding also decreases slightly with depth. This effect may be related to the paleogeothermal gradient or a change in the fo2 of the ground-water system.

The upper half of the core shows an inverse relationship between oxidation state of the Fe-Ti oxides and the degree of welding of the tuffs. The Topopah Spring tuff oxide microphenocrysts are virtually unaltered in the vitrophyre, show slight oxidation in the densely melded portions $\left(C_{3}\right)$, and higher oxidation in the partly welded zone $\left(C_{5}\right)$. The Calico Hills oxides reflect maximum oxidation states $\left(C_{5}-C_{7}\right)$ in the non- to slightly welded tuffs that comprise the unit. The Prow Pass Member ranges in degree of welding from non- to moderately welded, and the the oxides range from $\mathrm{C}_{7}$ to $C_{2}$, respectively. In a similar manner, the two major cooling units of the Bullfrog Member show the same relationship between permeability and maximum oxidation state. Only in a portion of the Tram is there deviation from this pattern. The upper portion of the Tram is quite consistent with the results presented above, but lower in the Tram ( 3258 to $3500 \mathrm{ft}$ ) nonwelded tuffs have 
oxides that are virtually unoxidized $\left(C_{2}\right)$. This effect can be correlated to the presence of pyrite in veins at that interval, indicating that reducing fluids permeated the tuffs.

In the Dacite flow breccia, oxides close to fractures are highly oxidized, whereas oxides any appreciable distance from fractures are unaltered. The oxide grains associated with the tuffs from 3940 to $5200 \mathrm{ft}$ show similar relations to degree of welding stated above. The difference is that the oxides are oxidized one step less for comparably welded tuffs (that is, $C_{5}-C_{6}$ for nonwelded and $C_{3}-C_{5}$ for partly welded). In the undivided sequence of tuffs from 5200 to $6000 \mathrm{ft}$, the opaque oxidation state is dictated only in part by the degree of welding. These oxides show appreciable reduction in their oxidation states. The sight reduction in oxidation from 3940 to $5200 \mathrm{ft}$ may be due in part to paieotemperature effects or else to changing ground water chemistry. The substantially reduced oxidation states from 5200 to $6000 \mathrm{ft}$ can reasonably be explained by fluids with lower fo2 values. These fluids were carbon dioxide rich; they pervasively deposited calcite in all samples in the lower 01der bedded and ash-flow tuff.

C. Comparison of USW-G1 with UE25a-1 and J-13

The lithologies and zeolite zones of USW-G1 are compared in Fig. 27 with those observed in UE25a-1 and $\mathrm{J}-13$. From the relative positions of the zeolite-zone boundaries, one can see some trends that may be significant for interpretation of regional al teration and hydrothermal history. The Zone I-II is difficult to place exactly in all three holes because it appears to occur in the wel ded portion of the Topopah Spring Member where it would not be seen because of primary devitrification to anhydrous phases on cooling. The Zone II-III boundary is observed in USW-GI and J-13 and provides an indication of maximum thermal gradients in each hole. The much narrower Zone II and higher level of Zone II-III boundary in $\mathrm{J}-13$ indicates a substantially higher maximum geothermal gradient in $\mathrm{J}-13$ than in USW-G1. This is consistent with $\mathrm{J}-13$ 's closer proximity to higher grade alteration zones in Calico Hills. The Zone II-III boundary was not observed in UE25a-1, but the apparent thickness of Zone II is consistent with this hole's intermediate position between USW-G1 and J-13. A deepening of UE25a-1 would allow firmer inferences to be drawn concerning past thermal regimes at the Yucca Mountain site. The Zone III-IV boundary was observed only in USW-G1, al though careful examination of samples from the lower units of $\mathrm{J}-13$ was not made.

\section{X-RAY POWDER DIFFRACTION ANALYSES}

A. Objectives

The two principal objectives of these analyses were to characterize the bulk mineralogy of the drill core for mineral phases and to estimate their proportions. The mineralogy of special features, such as fracture and cavityfilling minerals, and replacement phases after shards and pumice were also studied. Phase proportions are desired for qualitative interpretation of mineralogical changes, not for quantitative property determinations. Because of the extremely fine grain size of some of the secondary minerals and overlapping compositions of some of these phases, it is frequently difficult to identify phases by electron microprobe analysis. Sample preparation and $x$-ray diffraction (XRD) analysis were selected approximately every $15 \mathrm{~m}$. Where mineralogical changes are evident, samples were more closely spaced. 
For bulk XRD analysis, approximately $1 \mathrm{~g}$ of sample was removed from returned core using a steel hammer, if required. Harder (more welded) specimens were crushed in a steel stamp mill. All specimens were then ground in acetone in a porcelain mortar to less than 10 micron grain size (estimated). The grivund sample, suspended in acetone, was dispersed on a 5- $\times 5-\mathrm{cm}$ glass slide so that the sample covered the center $2-\times 2-\mathrm{cm}$ area to an approximate thickness of 100 to 200 microns.

Diffraction patterns were obtained using a Siemens model D-500 powder diffractometer equipped with a Cu-target $x$-ray tube and diffracted-bean monochromator. Patterns were run from $2^{\circ}$ to $36^{\circ} 20$ and recorded on a stripchart recorder. Samples were glycolated and patterns rerun from $2^{\circ}$ to $15^{\circ} 20$. Excess ground sample material is stored in the laboratory for future reference. Detailed procedures are outlined in Quality Assurance documents on file at Los Alamos.

C. Phase Identification

Minerals were identified from standards recorded by the Joint Committee on Powder Diffraction Standards (JCPDS) and secondary standards developed at this Laboratory. The minerals can be rapidly identified by recognition of characteristic peaks or pairs of peaks of distinctive relative intensities. In some cases, particularly for zeolite minerals, observed lattice spacings (d) were systematically smaller than those for JCPDS standards. This was attributed to differences in hydration states, and secondary standard patterns were prepared and used. Standard patterns, characteristic peaks, and interpretations are listed below.

1) Montmorillonite (JCPDS 13-239). This included various smectites (for example, montmorillonite, saponite, beidellite) plus interstratified smectite/ilitites. A low-angle peak occurs between 5 and $7^{\circ} 20$. The low-angle peak generaliy occurs at lower $2 \theta\left(4\right.$ to $\left.6^{\circ}\right)$ after glycolation, indicating a predominance of swelling $c l$ ays in interstratifications.

2) Mica/I11ite (illite JCPDS 2-462, biotite JCPDS 2-45, muscovite JCPDS 7-25). A characteristic peak occurs at 8.8 to $8.9^{\circ}(9.9$ to $10.0 \mathrm{~A})$. Because noninterstratified illite has not been identified in this core, this peak is a]most certainiy from various primary or secondary micas.

3) Clinoptilolite/Heulandite (JCPDS 21-131). Most peaks appear shifted to slightly larger $2 \theta$ (smaller d) perhaps as a result of differences in hydration state. Characteristic peaks occur at $22.8^{\circ}$ and $22.5^{\circ}$, plus two smaller peaks at $9.85^{\circ}$ and $11.25^{\circ}$.

4) Mordenite (JCPDS 6-239). Mordenite has peaks that overlap main peaks of clinoptilolite; however, characteristic peaks occur at $25.7^{\circ}$ and $19.8^{\circ}$. If major amounts of mordenite are present, minor anounts of clinoptilolite are difficult to distinguish.

5) Analcine (JCPDS 7-363). In decreasing order of height, characteristic peaks occur at $26.15^{\circ}, 15.9^{\circ}, 30.8^{\circ}, 33.5^{\circ}$, and $18.45^{\circ}$ 20. Serious overlap problems with these peaks were not encountered.

6) Quartz (JCPDS 5-490). Characteristic peaks occur at $26.55^{\circ}$ and $20.9^{\circ}$. In samples in which a secondary peak of alkali feldspar at $26.65^{\circ}$ possibly overlaps the main peak, the minor peak was used to determine small amounts of this wineral.

7) Cristobalite/Opal (JCPOS 11-695). Opal in these specimens is, almost exclusively, opal-ct, wich is an extremely fine-grained mixture of cristobalite, quartz, and amorphous material. In patterns of bulk specimens, 
sufficient detail is not available to distinguish opal from cristobalite, which is a common primary mineral occurring with sanidine in spherulites and in cavities within densely welded zones. The single characteristic peak at $21.9^{\circ}$ is overlapped by a minor peak of alkali feldspar so that identification of minor amounts of cristobalite and/or opal is difficult.

8) Alkali feldspars. A range of compositions and structures gives rise to some variability in peak locations and intensities. Strong characteristic peaks occur at $27.4^{\circ}, 27.8^{\circ}$, and $28.05^{\circ} 20$.

9) Calcite (JCPOS 5-586). A single characteristic peak without substantial overlap problems occurs at $29.5^{\circ} 20$. In calcite-rich samples minor peaks at $23.15^{\circ}$ and $31.6^{\circ}$ were also observed.

10) Glass. X-ray-amorphous silicate glass gives a broad intensity maximum between 20 and $30^{\circ} 20$. Minor amounts ( $20 \%$ ) of glass are not determinable in samples containing several phases that cause crowding of peaks in the range 20 to $30^{\circ} 2 \theta$.

11) Tridymite (JCPDS 14-260). The main peak occurs at $21.8^{\circ}$ with a slightly less intense peak at $20.7^{\circ}$. The larger peak is adjacent to cristobalite (21.9) and the smaller to quartz (20.9); however, in general, these are easily distinguished.

$24.7^{\circ} 2{ }^{\circ}$.

12) Siderite (JCPDS 8-133). Characteristic peaks occur at $32.05^{\circ}$ and

\section{Percentage Estimates}

The concentrations of various minerals present have been qualitatively estimated based on peak heights and areas (integrated intensities) relative to observed heights and areas in pure specimens. In doing this, several assumptions are made. First, all minerals have approximately the same average atomic number and thus have similar total scattering and absorption parameters. Second, significant preferred orientations are not present (but this is certainly not true for most clay- and mica-rich samples). Third, major variations in composition and structure do not occur within any given phase (not strictly true for feldspars). Fourth, sample preparation is the same for each sample.

Estimates reported in the Appendix are intended for qualitative interpretation of major mineralogical changes and are not for quantitative applications. Any application of these data should include consideration of the validity of the above assumptions and the overlap problems associated with specific mineral pairs outlined in the previous section. Approximate concentrations of phases are shown diagramitically as a function of depth in Fig. 31 .

\section{CONCLUSIONS AND RECOMENDATIONS}

A large volume of information about the hydrology, geology, geophysics, seismicity and Quarternary geomorphology of the Nevada Test Site has been published, some on open-file, by the U.S. Geological Survey. Many other organizations, including the Nevada Operations Office of the Department of Energy, Los Alamos National Laboratory, Sandia National Laboratory, and other national laboratories have added to this data base. The core drilling of USW-G1 at Yucca Mountain was done by the Nevada Nuclear Waste Storage Investigations as an important first step in determining whether this area contains a suitable stratigraphic unit of tuff in which to site a repository 


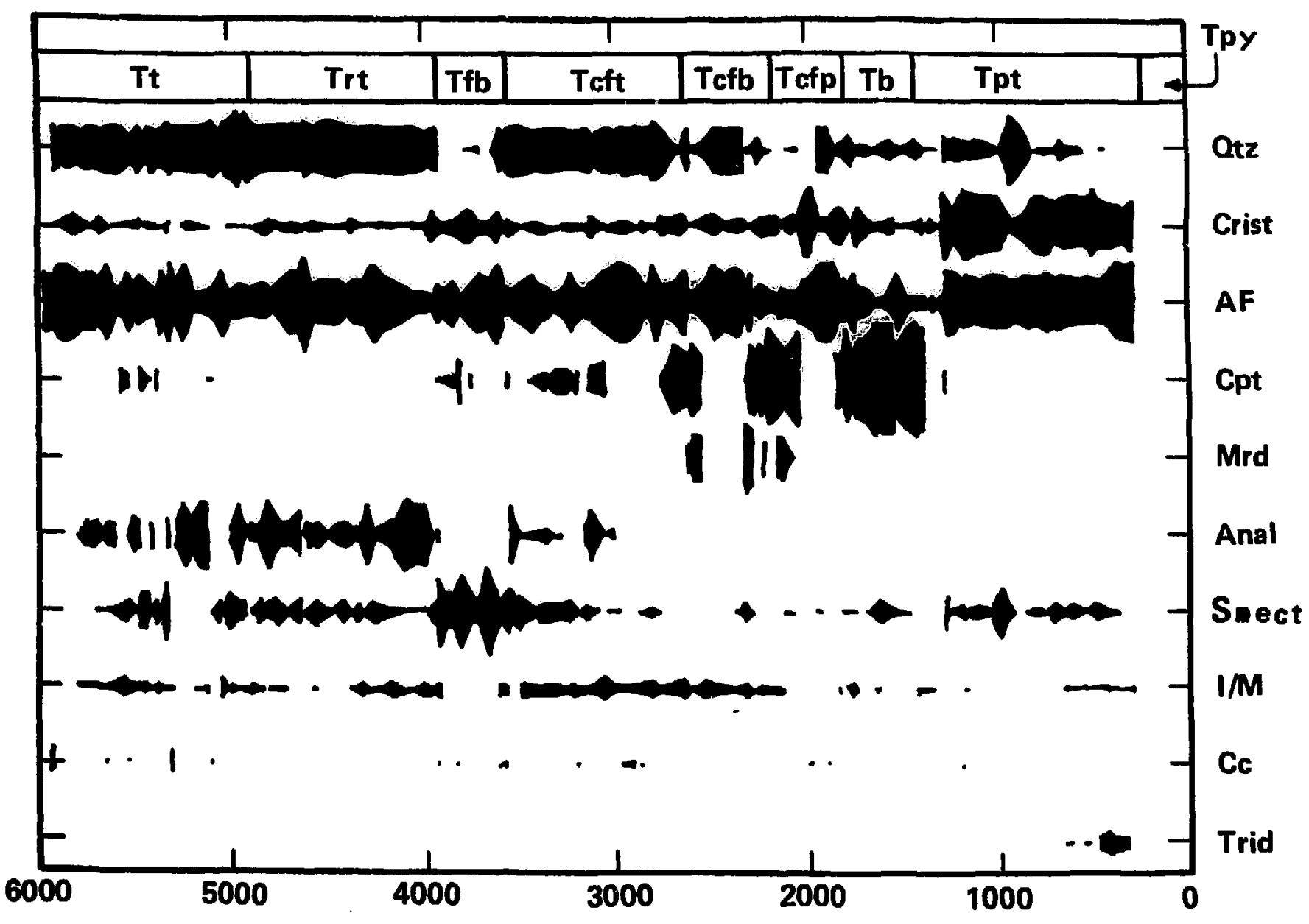

Fig. 31. Diagrammatic relative abundances of minerals in the USW-Gl core as a function of depth (in $\mathrm{ft}$ ). USW-Gl stratigraphy is also shown. Mineral identifications and estimates of abundance are by $x-r$ ay diffraction techniques. 
for permanent storage of nuclear wastes. Additional drilling is in progress. Thus, this preliminary report on stratigraphic and petrologic characterization of selected specimens from USW-G1 core is only a small part of a large, ongoing endeavor.

The data contained in this report, however, taken in connection with Spengler and associates' $10 \mathrm{~g}$ of the core, are sufficient to identify certain favorable (and unfavorable) stratigraphic tuff units in the search for a nuclear waste repository. A particularly promising candidate is a 975-ftthick ash-flow tuff within the unit cored as Lithic-rich tuff. It extends from 3946 to $4921 \mathrm{ft}$ in USW-G1. This ash flow has been tightly sealed by recrystalization of its original glass components by burial metamorphism. This tuff had reached the point in its alteration history where the typical minerals characteristic of the highest stage of Iijima's zeolite zones mere being replaced by minerals that mark the lowest stage of the Greenschist metamorphic facies. (A petrographic description of this tuff is in section III-H of this report.)

Thick sections of densely-welded ash-flow tuff have certain characteristics attractive for a waste repository. Anong these are better mechanical strength and themal conductivity than is typical of less-welded, glass-rich tuff (Johnstone and Wolfsberg, 1980), and reduced clinoptilolite abundance, which lessens the potential for disadvantageous, near-field, thermally induced mineral changes (Smyth and Caporuscio, 1981). In the USW-G1 core, representative sections of such densely welded tuff are found in the lower cooling unit of the Topopah Spring Member, the Bullfrog II cooling unit and the upper part of the Tram tuff. In the light of thermal modeling (Bulmer and Lappin, 1980), the latter two units may be too thin to absorb the increased heat from the repository before zeolitized horizons are affected. The Topopah contains a much thicker section of densely welded tuff [approximately 900-ft thick (Spengler et a1., in preparation)]. It is above the water table--a characteristic whose relative advantages or disadvantages are a matter of debate. Resolution of this question demands a more thorough characterization of the mineralogy and physical properties of these units.

Further detailed work on the petrologic, chemical, and physical characterization of tuff should be concentrated on the most favorable unit (or units) for a repository. It is time to focus the numerous experiments now being conducted on the chenical and physical nature of "tuff as a rock" into site-specific experiments on particular kinds of tuff present in those units of sufficient size and competence to form suitable candidates for a repository.

\section{ACKNOMLDGMENTS}

The core $\log$ and the specimens of core were obtained from the United States Geological Survey, and we also appreciate additional advice and encouragenent from R. W. Spengler and Frank $M$. Byers of that organization.

David A. Mann prepared excellent thin sections of tuffaceous materials that are very difficult to section, and Roland Hagan assisted with the microprobe and other laboratory work. Barbara Hahn and Edith Williams typed good copy from the scribblings of many authors, and the illustrations were prepared under the direction of $\mathrm{J}$. E. Tubb. Patricia O'Rourke prepared the final copy for publication. 
Barrows, K. J., 1980, Zeolitization of Miocene volcaniclastic rocks, southern Desatoya Mountains, Nevada: Geol. Soc. Aner. Bul1., v. 91, pp. 199-210.

Boles, J. R., 1972, Composition, optical properties, cell dimensions, and thermal stability of some heulandite group zeolites: Am. Mineral., v. 57, pp. 1463-1493.

Boles, J. R., 1977, Zeolites in deep-sea sediments: Min. Soc. Aner. Short Course Notes 4, pp. 137-163.

Bulmer, B. M., and Lappin, A. R., 1980, Preliminary one-dimensional thermal analysis of waste emplacement in tuffs: Sandia National Laboratories Report SAND79-1265.

Byers, F. M., Jr., Orkild, P. P., Carr, W. J., and Quinlivan, W. D., 1968, Timber Mountain Tuff, southern Nevada, and its relation to cauldron subsidence, in Eckel, E. B., ed., Nevada Test Site, Geol. Soc. Amer. Mem. 110 , pp. $87-98$.

Byers, F. M., Jr., Carr, W. J., Orkild, P. P., Quinlivan, W. D., and Sargent, K. A., 1976, Volcanic suites and related cauldrons of Timber Mountain-0asis Valley caldera complex, southern Nevada: U.S. Geol. Survey Prof. Paper 919, p. 70 .

Christiansen, R. L., Lipman, P. W., Carr, W. J., Byers, F. M., Jr., Orkild, P. P., and Sargent, K. A., 1977, Timber Mountain-Oasis valley caldera complex of southern Nevada: Geol. Soc. Amer. Bu11., v. 88, pp. 943-959.

Christiansen, R. L., and Lipman, P. W., 1965, Geologic map of The Topopah Spring NW quadrangle, Nye County, Nevada: U.S. Geol. Survey Quad. Map GQ-444.

Cook, E. F., 1965, Stratigraphy of Tertiary volcanic rocks in eastern Nevada: Nevada Bur. Mines, Report 11, p. 61.

Coombs, D. S., 1953, The nature and alteration of some Triassic sediments from Southl and, New Zeal and: Trans. Roy. Soc. New Zealand, v. 82, pp. 65-109.

Coombs, D. S., 1970, Present status of the zeolite facies: Amer. Chem. Soc. Adv., in Chem. Ser., v. 101, pp. 317-327.

Dixon, G. L., Carr, W. J., and Twenhofel, W. S., 1980, Earth science investigations for nuclear waste disposal at the Nevada Test Site: Geol. Soc. Amer. Abstracts, v. 12, no. 7, p. 414.

Fyfe, W. S., Turner, F. J., and Verhoogen, J., 1958, Metamorphic reactions and metamorphic facies: Geol. Soc. Amer. Menl. 85, pp. 215-217.

Haggerty, S. E., 1976, Oxidation of opaque mineral oxides in basalts, in Oxide minerals: Min. Soc. Amer. Short Course Notes, v. 3, pp. H6-1-H6-100. 
Hay, R. L., 1966, Zeolites and zeolitic reactions in sedimentary rocks: Geol. Soc. Amer. Spec. Paper 85, pp. 130-146.

Hay, R. L., 1978, Geologic occurrence of zeolites, in Sand, L. B., and Mumpton, F. A., eds., Natural zeolites, occurrence, properties, use: Elmsford, Hew York, Pergamon Press, pp. 135-143.

Heiken, G. H., and Bevier, M. L., 1979, Petrology of tuff units from the J-13 drili site, Jackass Flats, Nevada: Los Alamos National Laboratory report LA-7563-MS, p. 55.

Iijima, A., 1975, Effect of pore water to clinoptilolite-analcime-albite reaction series: J. Fac. Sci. Univ. Tokyo, Sec II, v. 19, pp. 133-147.

Iijima, A., 1978, Geological occurrences of zeolite in marine environments, in Sand, L. B., and Mumpton, F. A., eds., Natural zeolites, occurrence, properties, use: Elmsford, Hew York, Pergamon Press, pp. 175-198.

Iijima, A., 1980, Geology of natural zeolites and zeolitic rocks, in Rees, L. V., ed., Proceedings of Fifth Int. Conf. Zeolites: London, Heyden, pp. 103-118.

Ifjima, A., and Ohwa, I., 1980, Zeolitic burial diagenesis in Creta-Tertiary geosynclinal deposits of central Hokkaido, Japan, in Rees, L. V., ed., Proceedings of Fifth Int. Conf. Zeolites: London, Heyden, pp. 139-148.

Iijima, A., and Utada, M., 1971, Present-day zeolitic diagenesis of the Neogene geosynclinal deposits in the Niigata oil field, Japan; Amer. Chem. Soc. Adv., in Chem. Series 101, Molecular sieve zeolites - 1, pp. 342-349.

Johnstone, J.K., and Wolfsberg, K., eds., 1980, Evalutation of tuff as a mediun for a nuclear waste repository; an interim status report on the properties of tuff: Sandia National Laboratories report SAND80-1464.

Lappin, A. R., 1980, Thermal conductivity of silicic tuffs: predictive formalism and comparison with preliminary experimental results: Sandia National Laboratories report SAND80-0679.

Lofgren, G., 1971, Experimentally produced devitrification textures in natural rhyólitic glass: Geol. Soc. Amer. Bull., v. 82, pp. 111-124.

Perry, E. A., Jr., and Hower, J., 1970, Burial diagenesis in Gulf Coast pelitic sediments: Clays and Clay Min., v. 18, pp. 165-177.

Perry, E. A., Jr., and Hower, J., 1972, Late stage dehydration in deeply buried pelitic sediments: Am. Assoc. Petr. Geol. Bu11., v. 56, pp. 2013-2021.

Quinlivan, W. D., and Byers, F. M., Jr., 1977, Chemical data and variation diagrans of igneous rocks from the Timber Mountain-0asis Valley caldera complex, southern Mevada: U.S. Geol. Survey Open-File Report 77-724, p. 9. 
Sheppard, R. A., 1971, Zeolites in sedimentary rocks: U.S. Geol. Surv. Prof. Paper 820, pp. 689-695.

Sheppard, R. A., and Gude, A. J., 3rd, 1968, Distribution and genesis of authigenic silicate minerals in tuffs of Pleistocene Lake Tecopa, Inyo County, California: U.S. Geol. Survey Prof. Paper 597, p. 38.

Sheppard, R. A., and Gude, A. J., 3rd, 1969, Diagenesis of tuffs in the Barstow Formation, Mud Hills, San Bernadino County, California: U.S. Geol. Survey Prof. Paper 634, p. 34.

Smith, R. L., 1960, Zones and zonal variation in welded ash flows: U.S. Geol. Survey Prof. Paper 354-F, Pp. F149-F159.

Sinyth, J. R., and Caporuscio, F. A., 1981, Review of the thermal stability and cation exchange properties of the zeolite minerals clinoptilolite, mordenite, and analcime: applications to radioactive waste isolation in silicic tuff: Los Alamos National Laboratory report LA-8841-MS.

Spengler, R. W., Byers, F. M., Jr., and Warner, J. B., in preparation, Stratigraphy and structure of volcanic rocks in USW-G1, Yucca Mountain, Mye County, Nevada: U.S. Geol. Survey Open-File Reporţ.

Spengler, R. W., Muller, D. C., and Livermore, R. B., 1979, Preliminary report on the geology and geophysics of drill hole UE 25a-1, Yucca Mountain, Nevada Test Site: U.S. Geol. Survey Open-File Report 79-1244, p. 43.

Sykes, M. L., Heiken, G. H., and Smyth, J. R., 1979, Mineralogy and petrology of tuff units from the UE25a-1 drill site, Yucca Mountain, Mevada: Los A1 amos National Laboratory report LA-8139-MS, p. 76.

Turner, F. J., and Verhoogen, J., 1960, Igneous and Metamorphic Petrology: New York, McGraw Hill.

Vine, E. N., Aguilar, R. D., Bayhurst, B. P., Daniels, H. R., DeVilliers, S. J., Erdal, B. R., Lawrence, F. O., Maestas, S., Oliver, P. Q., Thompson, J. L., and Wol fsberg, K., 1980, Sorption-desorption studies on tuff II, a continuation of studies with samples from Jackass Flats, Nevada, and initial studies with samples from Yucca Mountain, Mevada: Los Alamos Scientific Laboratory report LA-8110-MS.

Winkler, H. G. F., 1965, Petrogenesis of metanorphic rocks: New York, Springer-Verlag, pp. 136-143.

Winograd, I. J. and W. Thordarson, 1975, Hydrogeologic and hydrochemical framework, South Central Great Basin, Nevada-California, with Special Reference to the Nevada Test Site, U.S. Geol. Surv. Prof. Paper no. 712-G, p. 126 .

Wolfsberg, K., Bayhurst, B. P., Crowe, B. M., Daniels, H. R., Erdal, B. R., Lawrence, F. O., Norris, A. E., and Smyth, J. R., 1979, Sorption-desorption studies on tuff I; initial studies with samples from the $\mathrm{J}-13$ dri11 site, Jackass Flats, Mevada: Los Alanos Scientific Laboratory report LA-7480-MS. 


\section{APPENDIX}

X-RAY DIFFRACTION ANALYSIS OF TUFF SAMPLES USW-G-1, 292 TO 5980 FT 
Samples USW-G-1, 292 to 5980 FT

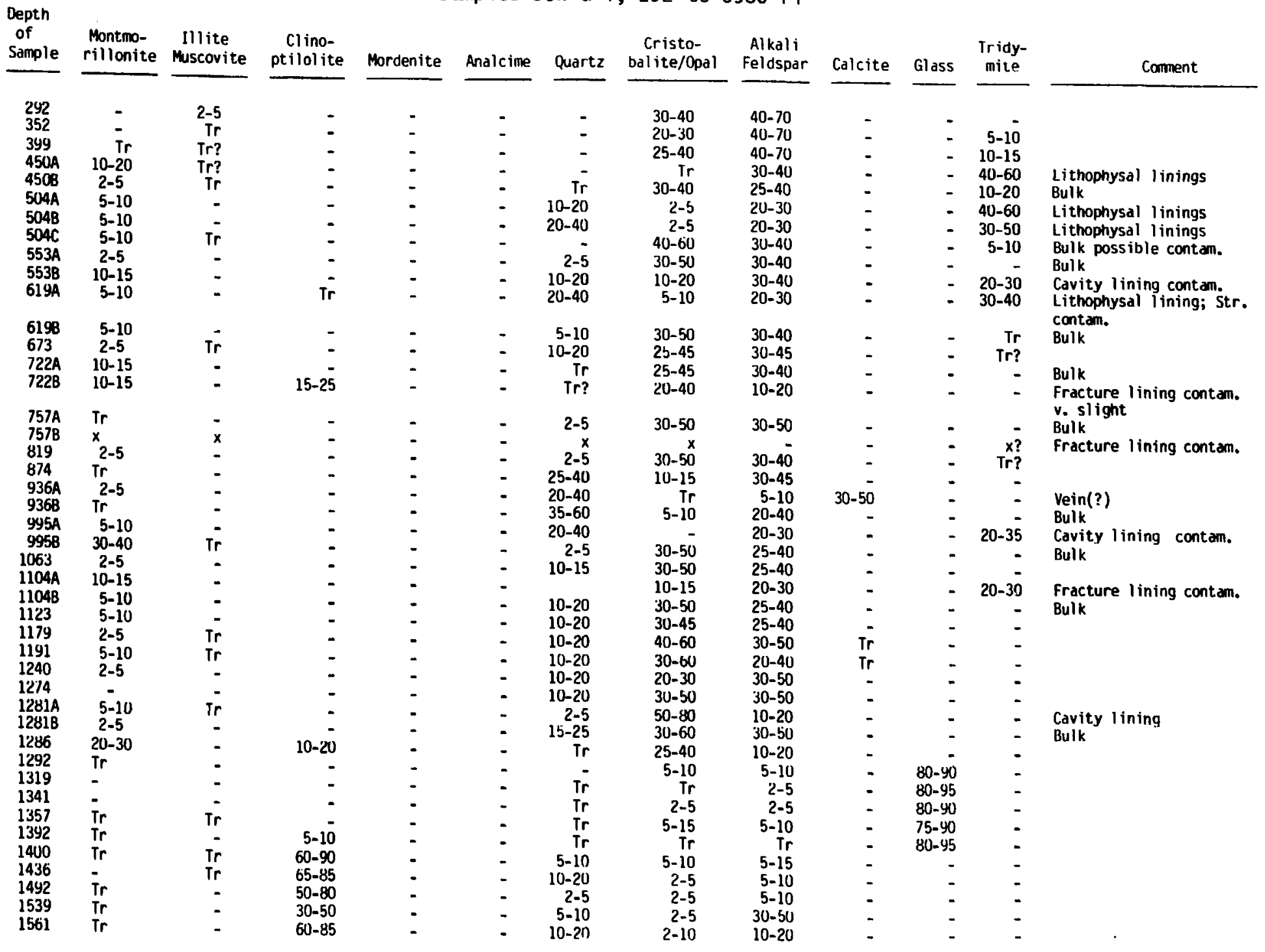


$X$-RAY DIFFRACTION ANALYSIS OF TUFF (cont'd.)

Samp les USW-G-1, 292 to $5980 \mathrm{FT}$

Depth

of Montmo- Illite Clino-

Sample

Clino-
ptilolite

Mordenite

Analcime

Quartz balite/0pal

Alkali

Feldspar Calcite

Glass

Tridy-

mite conment

$\begin{array}{llr}1639 & 10-20 & \mathrm{Tr} \\ 1693 & \mathrm{Tr} & - \\ 1748 & - & - \\ 1774 & \mathrm{Tr} & \mathrm{Tr} \\ 1784 & \mathrm{Tr} r & 5-10 \\ 1799 & \mathrm{Tr} & \mathrm{Tr} \\ 1819 & \mathrm{Tr} & - \\ 1854 & \mathrm{Tr} & 2-5 \\ 1883 & - & - \\ 1942 & 2-5 & \mathrm{Tr} \\ 1982 & \mathrm{Tr} & - \\ 2041 & \mathrm{Tr} & - \\ 2083 & \mathrm{Tr} & - \\ 2136 & 2-5 & \mathrm{Tr} \\ 2166 & - & \mathrm{Tr} \\ 2173 & \mathrm{Tr} & 2-5 \\ 2198 & \mathrm{Tr} & 2-5 \\ 2233 & \mathrm{Tr} & 2-5 \\ 2247 & - & 2-5 \\ 2289 & - & \mathrm{Tr} \\ 2290 & 2-5 & \mathrm{Tr} \\ 2316 & \mathrm{Tr} & 2-5 \\ 2318 & \mathrm{~T} r-20 & 2-10 \\ 2363 & 2-5 & 2-5 \\ 2436 & \mathrm{Tr} & 2-5 \\ 2486 & - & 2-5 \\ 2555 & \mathrm{Tr} & 2-10 \\ 2600 & - & \mathrm{Tr} \\ 2607 & - & \mathrm{Tr} \\ 2622 A & \mathrm{Tr} & 2-5 \\ 2622 B & - & 2-5 \\ 2641 & \mathrm{Tr} & 10-20 \\ 2698 & \mathrm{Tr} & 5-10 \\ 2748 \mathrm{~T} & \mathrm{Tr} & 5-10 \\ 2748 B & \mathrm{Tr} & \mathrm{Tr} \\ 2790 & \mathrm{Tr} & 2-5 \\ 2804 & 2-5 & 5-10 \\ 2854 & 2-5 & 5-10 \\ 2868 & \mathrm{Tr} & 5-10 \\ 2901 \mathrm{~A} & \mathrm{Tr} & 2-5 \\ 2901 \mathrm{~B} & \mathrm{Tr} & 2-5 \\ 2966 & \mathrm{Tr} & 2-5 \\ 3001 & 2-5 & 2-5 \\ 3053 & \mathrm{Tr} & 2-5 \\ 3116 & 2-5 & \end{array}$

\begin{tabular}{rrrr}
$60-90$ & - & - & $2-5$ \\
$40-70$ & - & - & $5-10$ \\
$40-60$ & - & - & $5-10$ \\
$30-70$ & - & - & $10-20$ \\
$15-30$ & - & - & $15-30$ \\
$40-70$ & - & - & $5-10$ \\
$20-30$ & - & - & $5-10$ \\
$25-40$ & - & - & $2-5$ \\
- & - & - & $25-40$ \\
- & - & - & $25-40$ \\
- & - & - & - \\
$50-80$ & - & - & $2-5$ \\
$40-60$ & $T r$ & - & $2-5$ \\
$25-50$ & $20-40$ & - & $\mathrm{Tr}$ \\
$30-60$ & $15-30$ & - & $\mathrm{Tr}$ \\
$30-70$ & - & - & $T r$ \\
$50-80$ & - & - & $\mathrm{Tr}$ \\
$20-40$ & $15-30$ & - & $5-10$ \\
$30-60$ & - & - & $10-30$ \\
$25-50$ & $30-50$ & - & $\mathrm{Tr}$ \\
$30-60$ & $30-50$ & - & $2-5$ \\
$20-30$ & $30-60$ & - & $2-5$ \\
- & - & - & $25-40$ \\
- & - & - & $25-40$ \\
- & - & - & $25-40$ \\
- & - & - & $25-40$ \\
$20-50$ & $20-40$ & - & $5-10$ \\
$30-60$ & $20-40$ & - & $2-5$ \\
$20-50$ & $10-20$ & - & $15-30$ \\
$20-50$ & $10-20$ & - & $25-40$ \\
$20-40$ & $10-20$ & - & $20-40$ \\
$25-40$ & - & - & $5-10$ \\
$30-60$ & - & - & $10-20$ \\
$5-10$ & - & - & $25-40$ \\
$2-5$ & - & - & $20-40$ \\
- & - & - & $30-50$ \\
- & - & - & $25-40$ \\
- & - & - & $25-40$ \\
- & - & - & $25-40$ \\
- & - & - & $25-40$ \\
$15-30$ & - & - & $20-30$ \\
$10-20$ & - & - & $25-40$ \\
- & - & $20-40$ \\
- & $-40-20$ & $25-40$ \\
- & - & $20-35$ \\
\hline & -40
\end{tabular}

$\begin{array}{rr}2-5 & 2-5 \\ 5-15 & 15-25 \\ 20-30 & 15-30 \\ 2-5 & 20-30 \\ 5-10 & 30-50 \\ 15-25 & 5-10 \\ 20-30 & 20-40 \\ 20-30 & 20-40 \\ 5-10 & 40-60 \\ 10-20 & 40-60 \\ 40-60 & 30-50 \\ 5-10 & 10-20 \\ 10-20 & 10-20 \\ 5-10 & 15-25 \\ 5-10 & 5-10 \\ 10-20 & 10-20 \\ 10-20 & 10-20 \\ 10-20 & 15-25 \\ 5-10 & 20-30 \\ 2-5 & 10-20 \\ 2-5 & 10-20 \\ 2-10 & 10-20 \\ 5-10 & 25-40 \\ 5-10 & 40-60 \\ 5-10 & 30-50 \\ 10-20 & 40-60 \\ 5-10 & 10-20 \\ 2-5 & 10-20 \\ 2-5 & 10-20 \\ 5-10 & 10-20 \\ 2-5 & 10-20 \\ 15-25 & 30-50 \\ 10-20 & 20-30 \\ 10-15 & 15-30 \\ 10-15 & 20-35 \\ 2-5 & 40-60 \\ 2-5 & 15-25 \\ 5-10 & 20-30 \\ 2-5 & 30-50 \\ 5-10 & 40-60 \\ 5-10 & 30-50 \\ 5-10 & 40-70 \\ 5-10 & 40-60 \\ 1 r & 30-50 \\ 5-10 & 20-30 \\ 2-5 & 10-20\end{array}$

Ok. Green Incl.

Bulk

Bulk

W/whitish altn.

Bulk

Cc vein 
X-RAY DIFFRACTION ANALYSIS OF TUFF (cont'd.)

Samples USW-G-1, 292 to $5980 \mathrm{FT}$

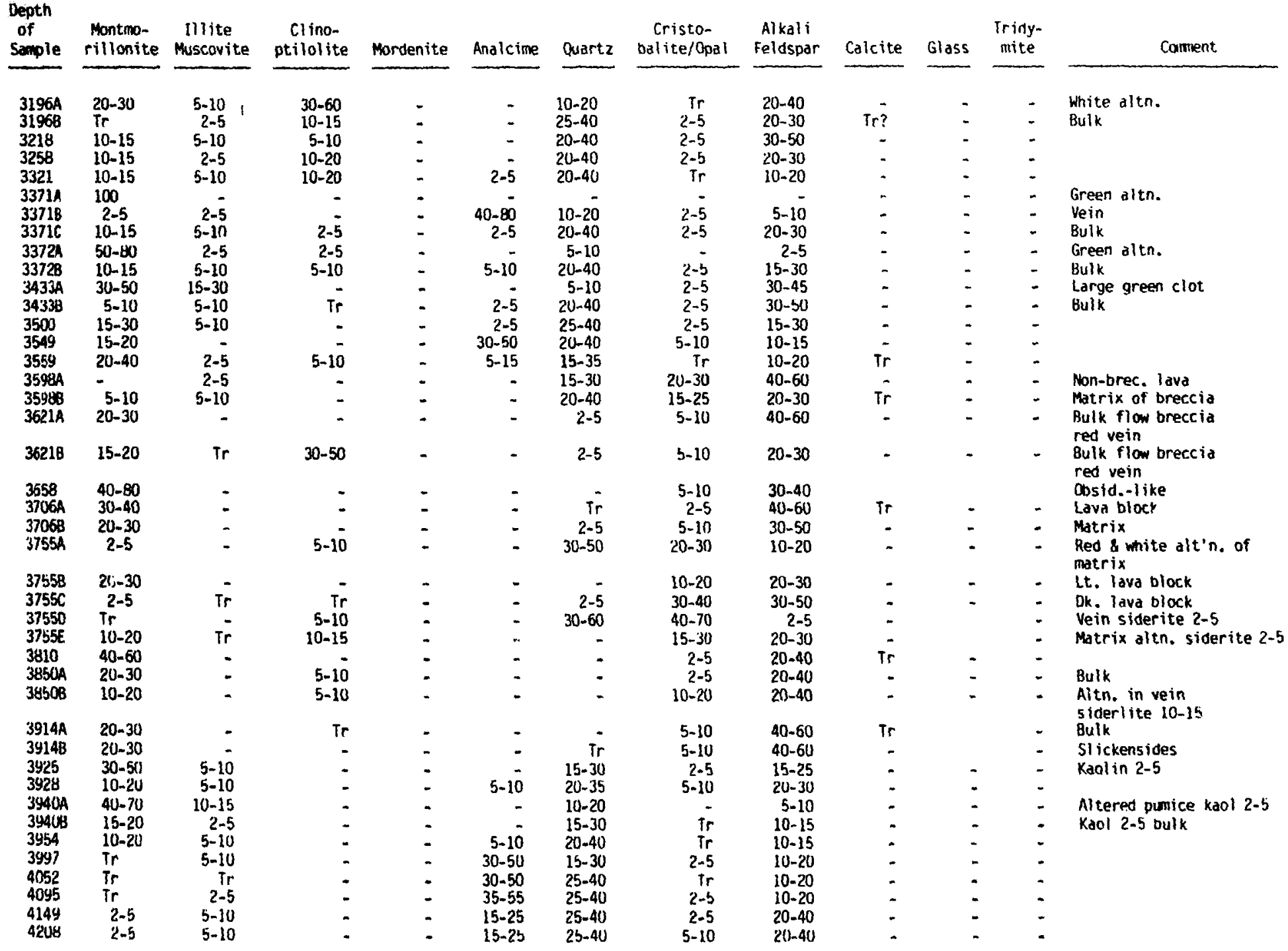


$X$-RAY DIFFRACTION ANALYSIS OF TUFF (cont'd.)

Samples USW-G-1, 292 to $5980 \mathrm{FT}$

\begin{tabular}{|c|c|c|c|c|c|c|c|c|c|c|c|c|}
\hline $\begin{array}{l}\text { Depth } \\
\text { of } \\
\text { Sample }\end{array}$ & $\begin{array}{l}\text { Montmo- } \\
\text { rillonite }\end{array}$ & $\begin{array}{l}\text { Illite } \\
\text { Muscovite }\end{array}$ & $\begin{array}{c}\text { Clino- } \\
\text { ptilolite }\end{array}$ & Mordenite & Analcime & Quartz & $\begin{array}{c}\text { Cristo- } \\
\text { balite/opal }\end{array}$ & $\begin{array}{l}\text { Alkali } \\
\text { Feldspar }\end{array}$ & Calcite & Glass & $\begin{array}{l}\text { Tridy- } \\
\text { mite }\end{array}$ & Comnent \\
\hline 4246A & 5-10 & & - & - & $40-60$ & $30-50$ & & $5-10$ & - & - & & White vein \\
\hline $4246 B$ & $10-15$ & $2-5$ & - & - & $\mathrm{Tr}$ & $25-40$ & $2-\overline{5}$ & $4 u-60$ & - & I & - & $\begin{array}{l}\text { minte vein } \\
\text { Bulk }\end{array}$ \\
\hline 4295 & $2-5$ & $\mathrm{Tr}$ & - & - & $30-50$ & $25-40$ & $2-5$ & $\begin{array}{l}40-00 \\
30-50\end{array}$ & - & 5 & - & Bulk \\
\hline 4321 & $10-15$ & $5-10$ & - & - & $2-5$ & $25-40$ & $2-5$ & $20-40$ & - & - & - & \\
\hline $4341 \mathrm{~A}$ & $60-80$ & $\mathrm{Tr}$ & - & - & & $10-15$ & - & $5-10$ & - & - & $=$ & Cream-gray altd. pumice \\
\hline 4341B & $2-5$ & $2-5$ & - & - & $5-10$ & $25-40$ & $2-\overline{5}$ & $20-40$ & - & - & $=$ & $\begin{array}{l}\text { Brealk-gray dita. pumice } \\
\text { Bulk }\end{array}$ \\
\hline $4357 \mathrm{~A}$ & $2-5$ & $2-5$ & - & - & $5-10$ & $25-40$ & $5-10$ & $20-40$ & - & - & - & Bulk \\
\hline 43578 & $50-80$ & $5-10$ & - & - & & $5-10$ & $2-5$ & $5-10$ & - & - & - & Cream-gray inclusion \\
\hline 4400 & $20-20$ & Tr & - & - & $15-25$ & $25-40$ & $2-5$ & $15-25$ & - & $=$ & $=$ & \\
\hline $\begin{array}{l}4451 \\
4503\end{array}$ & $\underset{5-10}{\operatorname{Tr}}$ & $\mathrm{Tr}$ & - & - & $10-15$ & $30-50$ & $\mathrm{Ir}$ & $20-40$ & - & 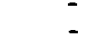 & - & \\
\hline $\begin{array}{l}4503 \\
4559 A\end{array}$ & $\operatorname{Tr}^{5-10}$ & Tr & - & - & $2-5$ & $30-50$ & $\mathrm{Tr}$ & $20-40$ & - & - & - & \\
\hline $\begin{array}{l}4559 \mathrm{~A} \\
45598\end{array}$ & Ir 20 & $\overrightarrow{I r}$ & - & - & $=$ & $15-30$ & $10-15$ & $30-50$ & - & - & - & Dk. xenol ith \\
\hline $\begin{array}{l}45598 \\
4612\end{array}$ & $\begin{array}{c}10-20 \\
2-5\end{array}$ & $\begin{array}{l}\mathrm{Tr} \\
\mathrm{Tr}\end{array}$ & - & $=$ & $\begin{array}{l}10-20 \\
10-20\end{array}$ & $20-40$ & $2-5$ & $20-30$ & - & $=$ & - & Bulk \\
\hline $\begin{array}{l}4012 \\
4626\end{array}$ & - & - & - & . & $\begin{array}{r}10-20 \\
T r\end{array}$ & $30-50$ & $2-5$ & $20-30$ & - & - & - & \\
\hline 4652 & $10-20$ & . & - & - & Ir & $25-40$ & $2-5$ & $50-70$ & - & - & - & \\
\hline 4700 & $.2-5$ & $2-5$ & $=$ & - & $\begin{array}{l}20-40 \\
10-20\end{array}$ & $25-40$ & Tr & $30-50$ & - & - & - & \\
\hline 4750 & $10-20 ?$ & $2-5$ & - & - & $\begin{array}{l}10-20 \\
10-20\end{array}$ & $25-40$ & $2-5$ & $30-50$ & - & - & - & \\
\hline $\begin{array}{l}4 / 50 \\
4805\end{array}$ & $5-10$ & Ir & 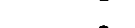 & & $10-20$ & $25-40$ & $2-5$ & $20-30$ & - & - & - & \\
\hline $\begin{array}{l}4805 \\
4848\end{array}$ & $10-15 ?$ & $\operatorname{Ir}_{\mathbf{T}}$ & - & - & $35-55$ & $25-40$ & $\mathrm{Tr}$ & $10-20$ & - & - & - & \\
\hline 4848 & $T=15 ?$ & Ir & - & - & $10-20$ & $25-40$ & $2-5$ & $20-30$ & - & - & - & \\
\hline 48764 & Tr & $2-5$ & - & - & $5-10$ & $25-40$ & $\mathrm{Tr}$ & $15-30$ & - & - & $=$ & Bulk \\
\hline $4876 \mathrm{~B}$ & $\overline{i r}$ & $\overline{-}$ & - & - & - & $10-15$ & $2-5$ & $2-5$ & $50-80$ & - & - & Gray vein \\
\hline $\begin{array}{l}4912 \\
4949\end{array}$ & $10-20$ & Ir & - & - & $5-10$ & $40-60$ & $\mathrm{Tr}$ & $15-25$ & $00-$ & $=$ & $=$ & or ay rem \\
\hline & $10-20$ & $\operatorname{Tr}$ & a & - & $10-20$ & $25-40$ & $\mathrm{Tr}$ & $20-30$ & - & . & - & \\
\hline $\begin{array}{l}4958 \\
44984\end{array}$ & $\begin{array}{l}10-20 \\
30-50\end{array}$ & Tr & - & - & $30-50$ & $40-60$ & $2-5$ & $20-30$ & - & - & - & \\
\hline $\begin{array}{l}499848 \\
4998 B\end{array}$ & $20-30$ & $2 \pi$ & - & - & & $20-35$ & - & $30-50$ & - & - & - & Altd. pumice \\
\hline $\begin{array}{l}49988 \\
5026\end{array}$ & $20=30$ & $\begin{array}{r}2-5 \\
T r\end{array}$ & - & - & $2-5$ & $25-40$ & $\mathrm{Tr}$ & $10-20$ & - & - & $=$ & $\begin{array}{l}\text { Ardk. parice } \\
\text { Bulk }\end{array}$ \\
\hline $\begin{array}{l}5026 \\
5049\end{array}$ & $10-20$ & Ir & $\begin{array}{l}- \\
-\end{array}$ & - & $=$ & $25-40$ & $\mathrm{Tr}$ & $30-50$ & - & - & - & \\
\hline $\begin{array}{l}5049 \\
5093\end{array}$ & $\begin{array}{c}10-20 \\
2-5\end{array}$ & $10-20$ & - & - & - & $15-30$ & - & $30-50$ & - & . & - & \\
\hline $\begin{array}{l}5093 \\
5126\end{array}$ & $2-5$ & $\therefore$ & Tr & - & - & $30-50$ & $\mathrm{Tr}$ & $20-30$ & $\mathrm{Tr}$ & - & - & \\
\hline $\begin{array}{l}5126 \\
5167\end{array}$ & $\begin{array}{l}\text { Tr } \\
\text { Tr }\end{array}$ & $2-5$ & - & - & $35-55$ & $25-40$ & $2-5$ & $10-20$ & - & . & - & \\
\hline $\begin{array}{l}516 / 1 \\
5212\end{array}$ & Tr & Tr & - & - & 35455 & $25-40$ & $2-5$ & $10-20$ & - & $=$ & $=$ & \\
\hline $\begin{array}{l}5212 \\
5253\end{array}$ & Tr & Tr & - & - & $15-25$ & $25-40$ & $2-5$ & $10-20$ & - & - & - & \\
\hline $\begin{array}{l}5253 \\
5 \% 296\end{array}$ & Tr & $\therefore$ & - & - & $30-50$ & $25-40$ & $\mathrm{Tr}$ & $40-60$ & - & . & - & \\
\hline 5296 & $\mathrm{Tr}$ & Tr & - & - & $10-20$ & $25-40$ & $\mathrm{Tr}$ & $20-30$ & $10-20$ & - & - & \\
\hline 5310 & $2-5$ & Tr & Tr? & - & 10-20 & $20-30$ & - & $40-60$ & - & - & - & \\
\hline $\begin{array}{l}5311 \\
5339\end{array}$ & & $\begin{array}{ccc}- & -1 & -1\end{array}$ & - & - & & $30-50$ & $5-10$ & $25-40$ & - & - & - & \\
\hline $\begin{array}{l}5329 \\
5230\end{array}$ & $\operatorname{Tr}$ & Tr & - & - & $15-25$ & $25-40$ & $2-5$ & $20-30$ & 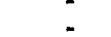 & :- & 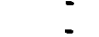 & \\
\hline 53338 & $30-50$ & $\operatorname{Tr}$ & $\mathrm{Tr}$ & - & 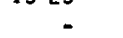 & 25.40 & $2-3$ & $15-25$ & $\mathrm{Tr}$ & - & - & \\
\hline 5348A & $\operatorname{Tr}$ & Ir & $\cdots$ & - & - & $2(0-35$ & $2-5$ & $30-60$ & & : & - & Bulk \\
\hline 53488 & Tr & $=$ & $x^{2}$ & - & - & $2-5$ & $=$ & & $9(1)-95$ & : & - & Wide vein \\
\hline 5378 & $i 0-20$ & $2-5$ & $10-20$ & - & 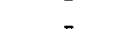 & $15-30$ & ir & $15-2 \overline{5}$ & 91)-95 & $:$ & - & Whoe vein \\
\hline 5412 & $\operatorname{Tr}$ & $\mathrm{Tr}$ & - & - & $10-25$ & $25-40$ & $2-5$ & $\begin{array}{l}11-20 \\
20-30\end{array}$ & : & $\therefore$ & - & \\
\hline 5433 & $20-30$ & 2.5 & $\operatorname{Tr}$ & - & - & $5-10$ & Ir & $20-30$ & - & . & - & \\
\hline 5458 & $20-30$ & $2-5$ & $10-20$ & - & - & $20-40$ & ir & $25-40$ & - & . & . & \\
\hline
\end{tabular}


X-RAY DIFFRACTION ANALYSIS OF TUFF (cont'd.)

Samp les USW-G-1, 292 to 5980 FT

\begin{tabular}{|c|c|c|c|c|c|c|c|c|c|c|c|c|}
\hline $\begin{array}{l}\text { Depth } \\
\text { of } \\
\text { Sample }\end{array}$ & $\begin{array}{l}\text { Montmo- } \\
\text { rillonite }\end{array}$ & $\begin{array}{c}\text { Illite } \\
\text { Muscovite }\end{array}$ & $\begin{array}{c}\text { Clino- } \\
\text { ptilolite }\end{array}$ & Mordenite & Analcime & Quartz & $\begin{array}{c}\text { Cristo- } \\
\text { balite/Opal }\end{array}$ & $\begin{array}{c}\text { Alkali } \\
\text { Feldspar }\end{array}$ & Caicite & Glass & $\begin{array}{l}\text { Tridy- } \\
\text { mite }\end{array}$ & Comment \\
\hline $\begin{array}{l}5477 \\
5498 \\
5534 \\
5560 \\
5596 \\
5637 \\
5679 \\
5699 \\
5746 \\
5803 \\
5847 \\
5898 \\
5947 A\end{array}$ & $\begin{array}{c}T r \\
2-5 \\
10-20 \\
5-10 \\
T r \\
T r \\
T r \\
T r \\
T r \\
T r \\
T r \\
T r \\
2-5 \\
10-20\end{array}$ & $\begin{array}{r}2-5 \\
2-5 \\
5-10 \\
10-15 \\
2-5 \\
2-5 \\
2-5 \\
2-5 \\
2-5 \\
2-5 \\
- \\
T r ? \\
T r\end{array}$ & $\begin{array}{r}5 \\
5-15 \\
10-20 \\
- \\
\vdots \\
- \\
- \\
- \\
-\end{array}$ & $\begin{array}{l}- \\
- \\
- \\
- \\
- \\
- \\
- \\
- \\
- \\
-\end{array}$ & $\begin{array}{r}15-25 \\
15-30 \\
\mathrm{Tr} \\
10-20 \\
10-20 \\
5-10 \\
10-20 \\
10-20 \\
\mathrm{Tr} ? \\
\mathrm{Tr} ? \\
-\end{array}$ & $\begin{array}{r}25-40 \\
25-40 \\
10-20 \\
20-40 \\
25-40 \\
25-40 \\
25-40 \\
25-40 \\
20-35 \\
20-40 \\
25-40 \\
15-30 \\
2-5\end{array}$ & $\begin{array}{r}T r \\
2-5 \\
T r \\
T r \\
T r \\
2-5 \\
2-10 \\
2-10 \\
2-5 \\
2-5 \\
10-15 \\
5-10 \\
2-5 \\
5-10\end{array}$ & $\begin{array}{l}25-40 \\
20-30 \\
30-50 \\
15-25 \\
15-25 \\
40-60 \\
25-40 \\
30-50 \\
30-50 \\
30-50 \\
40-60 \\
40-60 \\
40-60\end{array}$ & $\begin{array}{c}- \\
\\
\mathrm{Tr} \\
- \\
- \\
\mathrm{Ir} \\
\mathrm{Tr} ? \\
\mathrm{Ir} \\
\mathrm{Tr} \\
\mathrm{Tr} \\
- \\
\mathrm{Tr} \\
-\end{array}$ & $\begin{array}{l}- \\
- \\
- \\
- \\
- \\
- \\
- \\
- \\
-\end{array}$ & $\begin{array}{l}- \\
- \\
- \\
- \\
- \\
- \\
- \\
- \\
-\end{array}$ & $\begin{array}{l}\text { Neph? }(10-20) \\
\text { Kaol? Ir }\end{array}$ \\
\hline $\begin{array}{l}5947 \mathrm{~B} \\
5980\end{array}$ & $\begin{array}{l}\operatorname{Tr} \\
5-10\end{array}$ & $2-5$ & $2-5 ?$ & - & $10-20$ & $\begin{array}{r}25-40 \\
20-0\end{array}$ & $\begin{array}{r}2-5 \\
\mathrm{Tr}\end{array}$ & $\begin{array}{l}30-50 \\
30-50\end{array}$ & 15-30 & - & - & $\begin{array}{l}\text { Kaol? Ir, Green altered } \\
\text { pumice } \\
\text { Bulk (Mn-Calcite?) }\end{array}$ \\
\hline
\end{tabular}

